

\section{DISCLAIMER}

This report was prepared as an account of work sponsored by an agency of the United States Government. Neither the United States Government nor any agency Thereof, nor any of their employees, makes any warranty, express or implied, or assumes any legal liability or responsibility for the accuracy, completeness, or usefulness of any information, apparatus, product, or process disclosed, or represents that its use would not infringe privately owned rights. Reference herein to any specific commercial product, process, or service by trade name, trademark, manufacturer, or otherwise does not necessarily constitute or imply its endorsement, recommendation, or favoring by the United States Government or any agency thereof. The views and opinions of authors expressed herein do not necessarily state or reflect those of the United States Government or any agency thereof. 


\section{DISCLAIMER}

Portions of this document may be illegible in electronic image products. Images are produced from the best available original document. 
Printed in the United States of America. Available from National Technical Information Service

U.S. Department of Commerce

5285 Port Royal Road, Springfield, Virginia 22161

NTIS price codes-Printed Copy: A04 Microfiche A01

\section{DISCLAIMER}

This report was prepared as an account of work sponsored by an agency of the United States Government. Neither the United States Government nor any agency thereof, nor any of their employees, makes any warranty, express or implied, or assumes any legal liability or responsibility for the accuracy, completeness, or usefulness of any information, apparatus, product, or process disclosed, or represents that its use would not infringe privately owned rights. Reference herein to any specific commercial product, process, or service by trade name, trademark, manufacturer, or otherwise, does not necessarily constitute or imply its endorsement, recommendation, or favoring by the United States Government or any agency thereof. The views and opinions of authors expressed herein do not necessarily state or reflect those of the United States Government or any agency thereof.

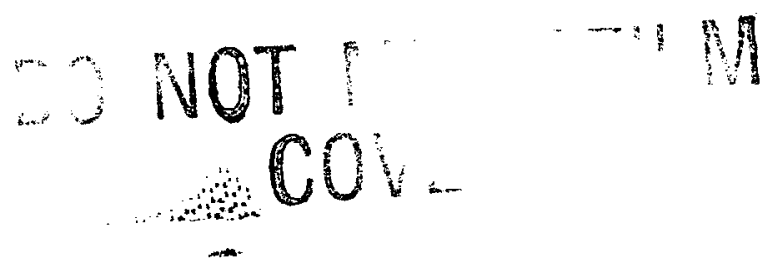


Date of Issue: December 31, 1986

Distribution Category: UC-25

\title{
CHARACTERIZATION OF URANIUM SURFACES MACHINED WITH AQUEOUS PROPYLENE GLYCOL-BORAX OR PERCHLOROETHYLENE-MINERAL OIL COOLANTS
}

\author{
S. S. Cristy \\ R. K. Bennett, Jr. \\ J. J. Dillon \\ H. L. Richards \\ R. D. Seals \\ V. R. Byrd
}

\section{DISCLAIMER}

\begin{abstract}
This report was prepared as an account of work sponsored by an agency of the United States Government. Neither the United States Government nor any agency thereof, nor any of their employees, makes any warranty, express or implied, or assumes any legal liability or responsibility for the accuracy, completeness, or usefulness of any information, apparatus, product, or process disclosed, or represents that its use would not infringe privately owned rights. Reference herein to any specific commercial product, process, or service by trade name, trademark, manufacturer, or otherwise does not necessarily constitute or imply its endorsement, recommendation, or favoring by the United States Government or any agency thereof. The views and opinions of authors expressed herein do not necessarily state or reflect those of the United States Government or any agency thereof.
\end{abstract}

Prepared by the

Oak Ridge $Y-12$ Plant

P.O. Box Y, Oak Ridge, Tennessee 37831

operated by

MARTIN MARIETTA ENERGY SYSTEMS, INC

for the

U.S. DEPARTMENT OF ENERGY

under contract DE-AC05-84OR21400 


\begin{abstract}
The use of perchloroethylene (perc) as an ingredient in coolants for machining enriched uranium at the Oak Ridge Y-12 Plant has been discontinued because of environmental concerns. A new coolant was substituted in December 1985, which consists of an aqueous solution of propylene glycol with borax (sodium tetraborate) added as a nuclear poison and with a nitrite added as a corrosion inhibitor.

Uranium surfaces machined using the two coolants were compared with respect to residual contamination, corrosion or corrosion potential, and surface morphology. Corrosion resistance of enriched uranium machined with the aqueous propylene glycol-borax coolant was found to be better than that of enriched uranium machined with the perc-mineral oil coolant. The boron residues on the final-finished parts machined with the borax-containing coolant were not sufficient to cause problems in further processing. All evidence indicates that the enriched uranium surfaces machined with the borax-containing coolant will be as satisfactory as those machined with the perc coolant.
\end{abstract}


CONTENTS

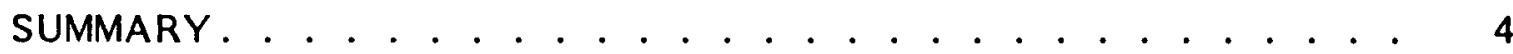

INTRODUCTION. . . . . . . . . . . . . . . . . 5

CHARACTERIZATION OF URANIUM SURFACES . . . . . . . 6

Presentation of Experimental Work. . . . . . . . . . . . 6

Surface Contamination. . . . . . . . . . . . . 7

Boron. . . . . . . . . . . . . . . . . 7

General Surface Contamination. . . . . . . . . . . 12

SIMS Studies................. 13

ESCA Studies. . . . . . . . . . . . . . . . 21

Determination of Oxide Corrosion Layer Thickness. . . . . . . 26

Surface Morphology and Local Corrosion. . . . . . . . . . . . 32

Accelerated Corrosion Testing. . . . . . . . . . . . . . 49

Coolant Characterization . . . . . . . . . . . . 51

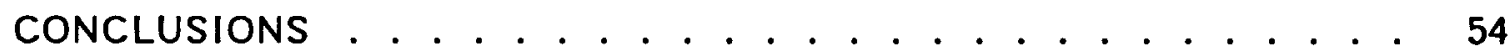

ACKNOWLEDGMENTS . . . . . . . . . . . . . 55

REFERENCES ....................... 56

Appendix. STATISTICAL ANALYSIS OF DATA . . . . . . . 57 


\section{SUMMARY}

Because of environmental concerns, perchloroethylene (perc) was eliminated as an ingredient in coolants used for machining enriched uranium at the Oak Ridge Y-12 Plant. A substitute coolant consisting primarily of an aqueous solution of propylene glycol and borax was formulated. The changeover to the new coolant occurred in December 1985. Thus, it is imperative to characterize uranium surfaces that have been machined with this new coolant and to compare them with those machined with the formerly used coolant with respect to residual contamination, corrosion or corrosion potential, and surface morphology to ensure that product quality and fitness for use are not endangered.

Enriched uranium machined with the aqueous propylene glycol-borax coolant was found to be more corrosion resistant than enriched uranium machined with the perc-mineral oil coolant. The boron residues on the final-finished parts machined with the borax-containing coolant are not sufficient to cause problems in further processing. All evidence indicates that the enriched uranium surfaces machined with the borax-containing coolant will be as satisfactory as those machined with the perc coolant. 


\section{INTRODUCTION}

The use of perchloroethylene (perc) as an ingredient in coolants for machining enriched uranium at the Oak Ridge $Y-12$ Plant was discontinued in December 1985 because of environmental concerns. A substitute coolant has been formulated and implemented. This coolant consists of an aqueous solution of propylene glycol (50-50 by volume) with $90 \mathrm{~g} / \mathrm{L}$ of borax (sodium tetraborate) added as a nuclear poison, $1000 \mathrm{mg} / \mathrm{L}$ of a nitrite added as a corrosion inhibitor, and $10 \mathrm{mg} / \mathrm{L}$ of azure blue dye added as a visual identifier. Thus, it is imperative to characterize uranium that has been machined with this new coolant and to compare it with uranium machined with the old coolant with respect to residual contamination, corrosion or corrosion potential, and surface morphology to ensure that product quality and fitness for use are not compromised by the coolant change. Of particular interest are the contamination and oxidation of surfaces that receive additional processing at the Rocky Flats Plant. 


\section{CHARACTERIZATION OF URANIUM SURFACES}

\section{PRESENTATION OF EXPERIMENTAL WORK}

The experimental work encompassed five major divisions: (1) surface contamination, with the major emphasis on the determination of boron residues; (2) characterization of the oxide and amount of oxide formation under normal conditions after machining; (3) characterization of the surface morphology and local corrosion of the machined uranium; (4) accelerated corrosion testing; and (5) coolant characterization. For each of these divisions, parts were machined in a normal manner with production and inspection resident times consistent with historic production experience. Parts machined with the perc coolant were compared with parts machined with the new boron-containing coolant.

Five of the test parts were packaged and sent to the Rocky Flats Plant for evaluation following certification. These five parts were exceptions in that the time spent at Warehouse 5 was reduced to $2 \mathrm{~d}$. A sixth part to simulate these was cut into samples and coupons at the shipment date. Two each of the test and production parts were unpacked and cut into samples after following the schedule shown in Table 1. Four production parts and three test parts were unpacked, cleaned with 1,1,1-trichloroethane (used at Rocky Flats for cleaning these parts before storage), repacked in plastic bags from Rocky. Flats, and stored on the high-rise storage racks in Building 9215 at $Y-12$. Two each of these were randomly selected and cut into samples after 1 month of storage. The remaining three parts will be stored for 6 months before being cut into samples.

Table 1. Average resident times for M-Wing part.

\begin{tabular}{lc}
\hline \multicolumn{1}{c}{ Location } & $\begin{array}{c}\text { Average } \\
\text { resident } \\
\text { time } \\
\text { (d) }\end{array}$ \\
\hline H-2 inspection & 3 \\
9212 radio & 4 \\
M-Wing dispatching (certify availability) & 3 \\
Quality liaison (certify) & 4 \\
M-Wing dispatching (cleaning and packing) & 14 \\
Warehouse 5 & 17 \\
Total time after M-Wing final-finish & 45 \\
machining & $29-55$ \\
Range of total time after final-finish & 3 \\
machining & 1 \\
Shipping to Rocky Flats & \\
Time before unpacking & \\
\hline
\end{tabular}


Table 2 is a summary of the parts and treatment history.

Table 2. Summary of parts and treatment history

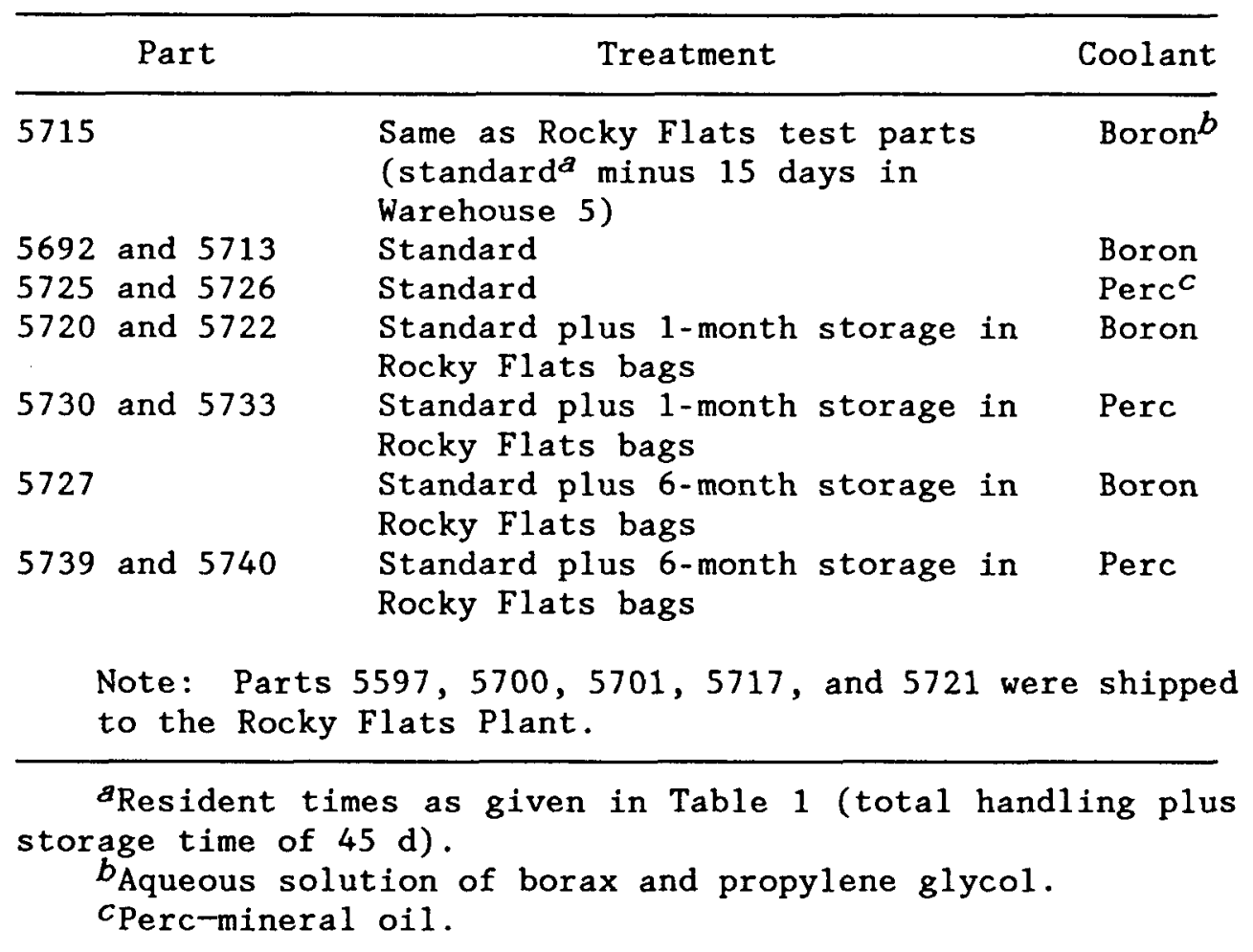

\section{SURFACE CONTAMINATION}

\section{Boron}

A prime reason for this study was to determine if the new coolant left detrimental residues or residues that might be construed as detrimental, particularly boron, on the surfaces of the completed parts. Thus machine turnings or chips from the first $0.005 \mathrm{in}$. of the surface were collected from the mouth, $45^{\circ}$, and pole areas on both the inner contour (IC) and outer contour (OC) of the parts (Fig. 1). Enough chips were collected to make at least $6 \mathrm{~g}$, and the surface area sampled was measured. These chips were then sent to the $Y-12$ Plant Laboratory for dissolution and boron analysis by inductively coupled plasma emission spectroscopy (ICP).

Bulk boron concentrations in the enriched uranium were obtained from chips or turnings from the debrimming or the face and step procedure; these concentrations were used as baseline data for the determination of surface boron by ICP analysis. The debrimming procedure is performed before semifinish machining and was done using the perc coolant. Table 3 shows these data. 


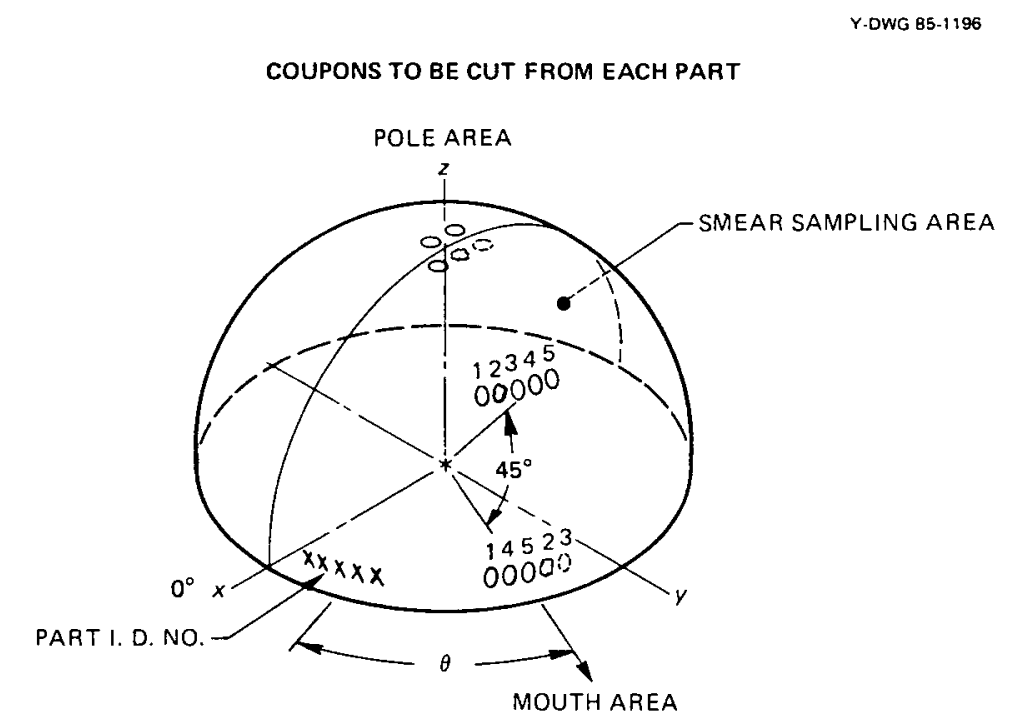

SAMPLE 1. ONE 0.7 in. DISK FROM EACH OF THE THREE LOCATIONS FOR IMMA AND SEM ANALYSIS

SAMPLE 2. CHIPS OR TURNINGS (5 g) CUT FROM THE FIRST 0.005 in. OF THE OC SURFACE AT EACH OF THE THREE LOCATIONS FOR ICP-SPECTROSCOPIC ANALYSIS

SAMPLE 3. CHIPS OR TURNINGS $(5 \mathrm{~g})$ CUT FROM THE FIRST 0.005 in. OF THE IC SURFACE AT EACH OF THE THREE LOCATIONS FOR ICP.SPECTROSCOPIC ANALYSIS

SAMPLE 4. ONE 0.75 -in. DISK FROM EACH OF THE THREE LOCATIONS FOR ESCA ANALYSIS

SAMPLE 5. ONE 1.3-in. DISK FROM EACH OF THE THREE LOCATIONS FOR ACT ANALYSIS

SAMPLE 6. 2.4-in. DISKS, CUT AS SELECTED BY S. S. CRISTY

Fig. 1. Coupons to be cut from each part.

Table 3. Bulk ICP data from debrimming operation (Values are parts per million by weight.)

\begin{tabular}{lcccccccccc}
\hline Part & B & C & Cr & A1 & Mn & Cu & Mo & Fe & Si & Ni \\
\hline 5725 & 0.36 & 375 & 10 & 20 & 10 & 10 & 50 & 100 & 175 & 30 \\
5726 & 0.29 & 379 & 20 & 20 & 10 & 10 & 50 & 100 & 200 & 20 \\
5730 & 0.25 & 420 & 20 & 20 & 10 & 10 & 60 & 100 & 200 & 22 \\
5733 & 0.41 & 396 & 20 & 30 & 10 & 10 & 50 & 100 & 200 & 30 \\
5739 & 0.44 & 377 & 20 & 20 & 15 & 10 & 60 & 100 & 200 & 40 \\
5740 & 0.42 & 383 & 20 & 20 & 15 & 15 & 50 & 100 & 175 & 40 \\
& & & & & & & & & & \\
Average & 0.36 & 388 & 13 & 22 & 13 & 11 & 53 & 100 & 192 & 30 \\
& \pm 0.08 & & & & & & & & & \\
\hline
\end{tabular}

The boron measurements from a second set of data varied more widely than those of this set and were not considered reliable. The boron in the substrate or bulk uranium may not be very homogeneously distributed, 
thus leading to erroneous corrections when reducing the ICP data to determine surface boron from chips. The value of $0.36 \mathrm{ppm}$ of boron in the uranium substrate was used to calculate the surface boron by difference.

Table 4 summarizes the amounts of surface contaminant boron as determined using chip data from the boron coolant-machined parts. The statistical $F$ test applied to these data indicated that the quantity of IC surface boron was significantly greater than the quantity of $O C$ surface boron. This same test indicated that the differences observed between pole, $45^{\circ}$, and mouth positions were also significant. On the IC, boron increased in the order of pole, $45^{\circ}$, mouth, whereas on the OC, the order was reversed (Fig. 2).

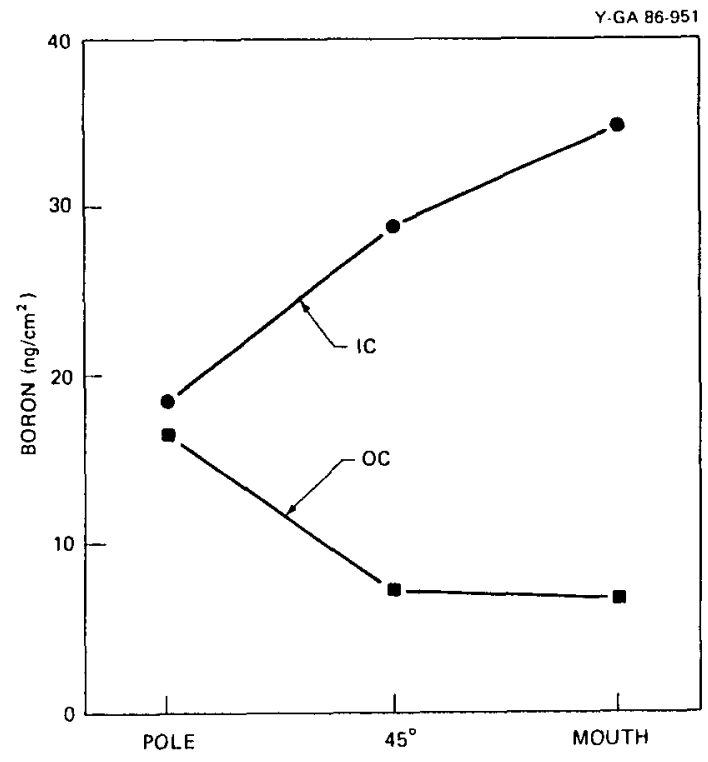

Fig. 2. Surface boron from chip data as a function of location.

Chip data were collected from only one of the perc-cut parts-part 5725, which had the standard handling treatment. The chips from the six locations on this part averaged $0.29 \pm 0.05 \mathrm{ppm}$, less than the $0.36 \mathrm{ppm}$ found for the bulk uranium (Table 3 ). Thus, the surface boron can only be said to be below our limits of certification.

As can be seen from Table 4, determination of boron by chip dissolution and ICP analysis yields data that vary greatly. The probable cause is a significant but inhomogeneously distributed quantity of boron in the base uranium. To circumvent this inhomogeneity and obtain an independent measure of the surface boron, two $6-\mathrm{cm}$-diam disks were cut from each part and acid leached to remove a thin layer of the surface and thus the boron residues. Boron and uranium in the leachant were 
Table 4. Chip data defermination of boron residues on part surfaces from boron coolant-machined parts

\begin{tabular}{|c|c|c|c|c|}
\hline Part & Treatment & & $\begin{array}{c}\text { Boron } \\
\left(\mathrm{ng} / \mathrm{cm}^{2}\right)\end{array}$ & Surface \\
\hline 5715 & $\begin{array}{l}\text { Same as Rocky Flats } \\
\text { test parts }\end{array}$ & Average & $\begin{array}{l}8.4 \\
43 \\
36 \\
29\end{array}$ & $\begin{array}{l}\text { IC pole } \\
\text { IC } 45^{\circ} \\
\text { IC mouth } \\
\text { IC }\end{array}$ \\
\hline 5715 & $\begin{array}{l}\text { Same as Rocky Flats } \\
\text { test parts }\end{array}$ & Average & $\begin{array}{l}27 \\
6.3 \\
0 \\
11\end{array}$ & $\begin{array}{l}\text { OC pole } \\
\text { OC } 45^{\circ} \\
\text { OC mouth } \\
\text { OC }\end{array}$ \\
\hline 5715 & & Average & 20 & $O C+I C$ \\
\hline 5692 & Standard & Average & $\begin{array}{l}24 \\
42 \\
34 \\
33\end{array}$ & $\begin{array}{l}\text { IC pole } \\
\text { IC } 45^{\circ} \\
\text { IC mouth } \\
\text { IC }\end{array}$ \\
\hline 5692 & Standard & Average & $\begin{array}{l}7.7 \\
20 \\
18 \\
15\end{array}$ & $\begin{array}{l}\text { OC pole } \\
\text { OC } 45^{\circ} \\
\text { OC mouth } \\
\text { OC }\end{array}$ \\
\hline 5692 & & Average & 24 & $O C+I C$ \\
\hline 5713 & Standard & Average & $\begin{array}{l}36 \\
31 \\
46 \\
38\end{array}$ & $\begin{array}{l}\text { IC pole } \\
\text { IC } 45^{\circ} \\
\text { iC mouth } \\
\text { ic }\end{array}$ \\
\hline 5713 & Standard & Average & $\begin{array}{l}45 \\
10 \\
14 \\
23\end{array}$ & $\begin{array}{l}\text { OC pole } \\
\text { OC } 45^{\circ} \\
\text { OC mouth } \\
\text { OC }\end{array}$ \\
\hline 5713 & & Average & 30 & $O C+I C$ \\
\hline 5720 & $\begin{array}{l}\text { Standard plus } \\
1 \text {-month storage in } \\
\text { Rocky Flats bags }\end{array}$ & Average & $\begin{array}{l}24 \\
28 \\
57 \\
36\end{array}$ & $\begin{array}{l}\text { IC pole } \\
\text { IC } 45^{\circ} \\
\text { IC mouth } \\
\text { IC }\end{array}$ \\
\hline 5720 & $\begin{array}{l}\text { Standard plus } \\
1 \text {-month storage in } \\
\text { Rocky Flats bags }\end{array}$ & Average & $\begin{array}{l}3.5 \\
0 \\
2.8 \\
2.8\end{array}$ & $\begin{array}{l}\text { OC pole } \\
\text { OC } 45^{\circ} \\
\text { OC mouth } \\
\text { OC }\end{array}$ \\
\hline 5720 & & Average & 19 & $I C+O C$ \\
\hline 5722 & $\begin{array}{l}\text { Standard plus } \\
1 \text {-month storage in } \\
\text { Rocky Flats bags }\end{array}$ & Average & $\begin{array}{l}0 \\
0 \\
1.1 \\
0.4\end{array}$ & $\begin{array}{l}\text { IC pole } \\
\text { IC } 45^{\circ} \\
\text { IC mouth } \\
\text { IC }\end{array}$ \\
\hline 5722 & $\begin{array}{l}\text { Standard plus } \\
1 \text {-month storage in } \\
\text { Rocky Flats bags }\end{array}$ & Average & $\begin{array}{l}0 \\
0 \\
0 \\
0\end{array}$ & $\begin{array}{l}\text { OC pole } \\
\text { OC } 45^{\circ} \\
\text { OC mouth } \\
\text { OC }\end{array}$ \\
\hline 5722 & & Average & 0.2 & $O C+1 C$ \\
\hline \multicolumn{5}{|c|}{$\begin{array}{l}\text { Grand averages and standard } \\
\text { deviation }\end{array}$} \\
\hline
\end{tabular}


determined by ICP spectrographic analysis. This method of sample preparation does not remove enough substrate or bulk uranium for the boron from this source to be analytically significant. A minor drawback is that ICs and OCs are not separated by this method. In Table 5, the results are compared with the sums of the $I C$ and $O C$ boron as determined from the chip data.

Table 5. Average boron residues for part surfaces

$(I C+O C)$ determined from surface chips and

from acid leachings

\begin{tabular}{lccl}
\hline & \multicolumn{2}{c}{ Boron $\left(\mathrm{ng} / \mathrm{cm}^{2}\right)$} & \\
\cline { 2 - 3 } Part & Acid leaching & Surface chips & Coolant \\
\hline 5715 & 12 & 20 & Boron \\
5692 & 19 & 24 & Boron \\
5713 & 16 & 30 & Boron \\
5720 & 16 & 19 & Boron \\
5722 & 13 & 0.2 & Boron \\
5727 & 16 & $\mathrm{ND}^{a}$ & Boron \\
5725 & $\mathrm{ND}$ & $\mathrm{LDL}$ & Perc \\
5726 & $<7$ & $\mathrm{ND}$ & Perc \\
5730 & $<3$ & $\mathrm{ND}$ & Perc \\
5733 & $<3$ & $\mathrm{ND}$ & Perc \\
5739 & $<3$ & $\mathrm{ND}$ & Perc \\
5740 & $<3$ & $\mathrm{ND}$ & Perc \\
& & & \\
Average & $15 \pm 3$ & $19 \pm 15$ & Boron \\
Average & $\mathrm{LDL}$ & $\mathrm{LDL}$ & Perc \\
\hline
\end{tabular}

$a_{\text {Not determined. }}$.

$b_{\text {Less }}$ than detection limit.

Since a nondestructive technique for determining boron residues on surfaces would be desirable, a smear sampling method was tried. A 47-mm-diam cellulose acetate Millipore filter was found to be tough enough to withstand vigorous hand scrubbing of a part surface and was chosen for use over a Whatman filter, which crumbled with the same treatment. The filter was wet with triply distilled water, and an area of $\sim 123 \mathrm{~cm}^{2}$ was scrubbed with three filters. Approximately $20 \mathrm{~mL}$ of this water was used to rinse the scrubbed area and was collected with the filter papers. The filter papers were then digested, and the boron in the solutions was measured by ICP.

It was also of interest to determine whether boron residues on semifinish surfaces were comparable to those on final finishes and whether OCs were comparable to ICs. The boron on the semifinish ICs of 11 boron coolant-machined parts averaged $52 \mathrm{mg} / \mathrm{cm}^{2}$ with a standard deviation of $\pm 57 \mathrm{ng} / \mathrm{cm}^{2}$. On the perc machined parts, boron averaged $<8 \mathrm{ng} / \mathrm{cm}^{2}$. On the final-finish surfaces, which included OC smears on 
the five Rocky Flats parts and IC and OC smears on the other six boron coolant-machined parts and on the six perc coolant-machined parts, all boron determinations were below the detection limit of $\sim 8 \mathrm{ng} / \mathrm{cm}^{2}$.

To determine the effectiveness of the smearing technique for final-finish determinations, a 6 -cm-diam coupon was cut from each of two smeared and two nonsmeared areas of two parts and acid leached. The results for smeared and nonsmeared were virtually identical. If one should be able to distinguish detection limit differences at these low levels (three to five times the detection limit), then the smearing technique used can be no more than $30 \%$ effective in removing boron from the final-finish surfaces.

It was thought that possibly the oiling treatments received after final finishing created a barrier to the water scrubbing treatments and thus reduced the effectiveness of the smearing. To test this hypothesis, mixtures of acetone and water or acetone, water, and a surfactant were used as the solvent medium for scrubbing the surface with polyvinylidene fluoride Millipore filters. Acetone and surfactant were added to help dissolve any residual oils. (The type of filter was changed to be compatible with the acetone.) Three boron coolant-machined parts, 5715, 5713, and 5692, were scrubbed on undisturbed portions of the IC with these solutions. The boron removed was still below the detection limit of $\sim 8 \mathrm{ng} / \mathrm{cm}^{2}$. Thus if a nondestructive method is needed in the future for determining these very low levels of boron residues on finished parts, additional development work will be required.

In summary, the boron residues on the final-finish machined parts were quite low. In each case the boron levels were close to the detection limits for the very sensitive ICP spectrometer. By acid etching, considered the most reliable of the techniques, the total boron residues were found to be $15+3 \mathrm{ng} / \mathrm{cm}^{2}$. The use of chips resulted in problems, but the net result of $19+15 \mathrm{ng} / \mathrm{cm}^{2}$ substantiates the acid etching results. The chip data indicate that the IC surfaces average somewhat more boron than found on the OC surfaces. Overall, this level of boron is not considered to be a problem for the processing done at the Rocky Flats Plant.

\section{General Surface Contamination}

General surface contamination was surveyed by secondary ion mass spectrometry (SIMS) and by electron spectroscopy for chemical analysis (ESCA). Inner and outer contours of all samples were analyzed with SIMS, and all inner contour surfaces were analyzed with ESCA. An Applied Research Laboratories (ARL) ion microprobe mass analyzer (IMMA) utilized a $20-\mathrm{keV} \mathrm{N}_{2}{ }^{+}$primary ion beam for all SIMS analyses. The McPherson ESCA 36 photoelectron spectrometer used $\mathrm{Al} \mathrm{K \alpha}$ radiation at $250 \mathrm{~W}(12.5 \mathrm{kV}$ at $20 \mathrm{~mA})$ for analyses. Just prior to insertion into either instrument, the disks were flushed with Freon to remove the surface oil that had been applied after cutting to improve storage. 


\section{SIMS Studies}

All SIMS secondary-ion spectra in this report are normalized to the most intense peak in the spectrum. All negative ion spectra are normalized to $\mathrm{O}^{-}$; positive ion spectra are normalized to $\mathrm{UO}^{+}$except for the mass spectrum in Fig. 3 , in which the most intense peak is $\mathrm{UO}_{2}{ }^{+}$. Outer contour spectra tended to be more intense due to geometry effects of the curved surfaces.

Positive secondary-ion spectra from the mouth area of part 5715 (like Rocky Flats test parts) are shown in Figs. 3(a) through 4(c). A large number of elements are observed on these surfaces including $\mathrm{H}, \mathrm{Li}, \mathrm{B}, \mathrm{C}$, $\mathrm{O}, \mathrm{Na}, \mathrm{Mg}, \mathrm{Al}, \mathrm{Si}, \mathrm{P}, \mathrm{Cl}, \mathrm{K}, \mathrm{Ca}, \mathrm{Ti}, \mathrm{Cr}, \mathrm{Fe}, \mathrm{Mn}, \mathrm{Ni}, \mathrm{Co}, \mathrm{Cu}, \mathrm{Zn}, \mathrm{Sr}, \mathrm{Ba}$, $\mathrm{Pb}$, and $\mathrm{U}$. In general, the spectra of the inside and outside surfaces were similar. There appeared to be a little more boron on the inside surface, which agreed with the chip data above. (For perspective, remember the measured boron levels averaged $29 \mathrm{ng} / \mathrm{cm}^{2}$ on the $I C$ and $11 \mathrm{ng} / \mathrm{cm}^{2}$ on the OC. Also, compare the ESCA spectrum on the IC surface in Fig. 13, which shows only uranium, oxygen, carbon, and traces or minor peaks due to calcium and sulfur.)

Negative secondary-ion spectra show those elements that preferentially form negative ions. Figures 5 and 6 show the negative ion spectra from the $O C$ and $I C$ in the mouth area of part 5715. Both show considerable oxygen, chlorine, carbon, and fluorine on these surfaces. All the peaks above mass 40 are combination peaks formed from some of these four elements and possibly hydrogen or nitrogen. No significant differences in the spectra from the mouth, $45^{\circ}$, and pole areas were found. Thus, the secondary-ion spectra from the latter two areas are not included.

Figures 7 (a) through $8(\mathrm{c})$ show the positive secondary-ion spectra from the $O C$ and IC surfaces of standard treatment, boron coolant-machined sample 5713. These mass spectra are quite similar to those from part 5715. One difference, however, is the presence of silver, seen in Fig. 7(b). Silver was not seen on any of the other spectra from the 5715 or matching part 5692 coupons. As with part 5715, boron was slightly more intense on the IC surface.

The negative secondary-ion spectra from part 5713 are shown in Figs. 9 and 10. Again, oxygen, chlorine, carbon, and fluorine are the dominant negative peaks. The $\mathrm{OH}$ peaks are relatively higher and the chlorine, carbon, and fluorine peaks relatively lower on these standard treatment samples than on the samples like those sent to Rocky Flats. This difference probably reflects the additional time that the standard samples had to adsorb moisture and to oxidize.

The secondary-ion mass spectra from the surfaces of the perc-machined parts are similar to those of the boron coolant-machined parts. The positive secondary-ion mass spectrum from the $45^{\circ}$ IC of part 5726 (standard treatment, perc-machined) is shown in Fig. 11 . In comparing this spectrum with that of its counterpart from a boron-coolant surface (Fig. 8), it is observed that although the boron 


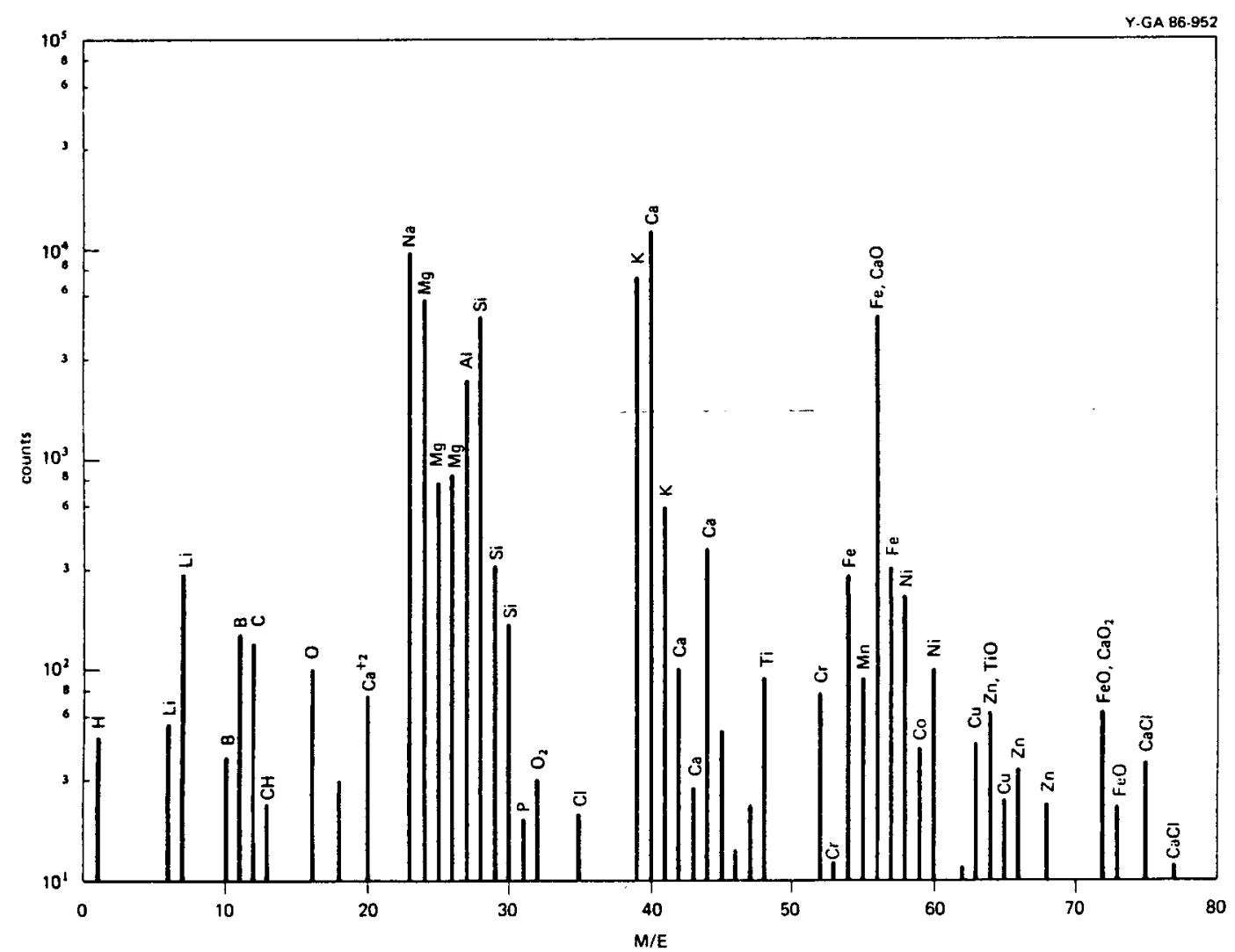

Fig. 3a. Positive mass spectrum from outer contour of part 5715, mouth area, mass range $0-80$.

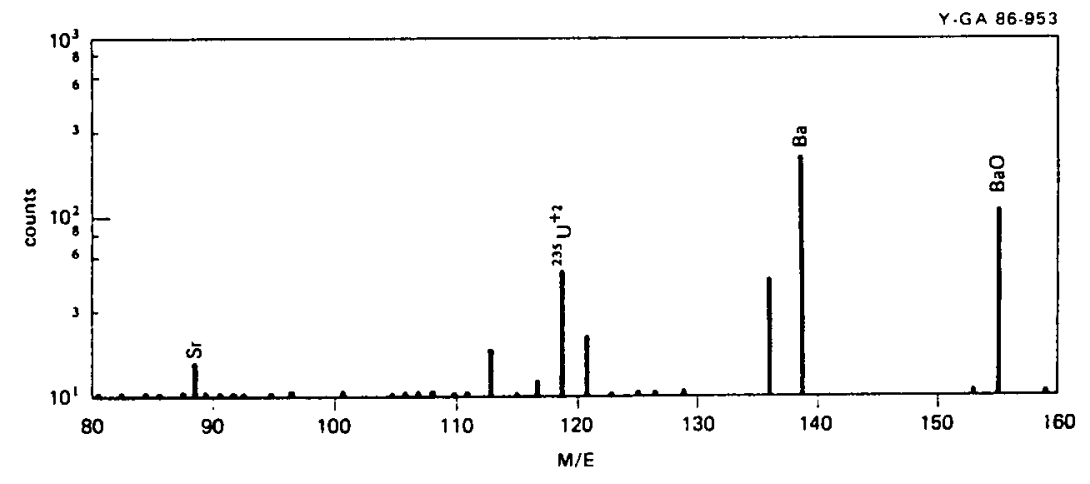

Fig. 3b. Positive mass spectrum from outer mouth contour of part 5715, mouth area, mass range 80-160.

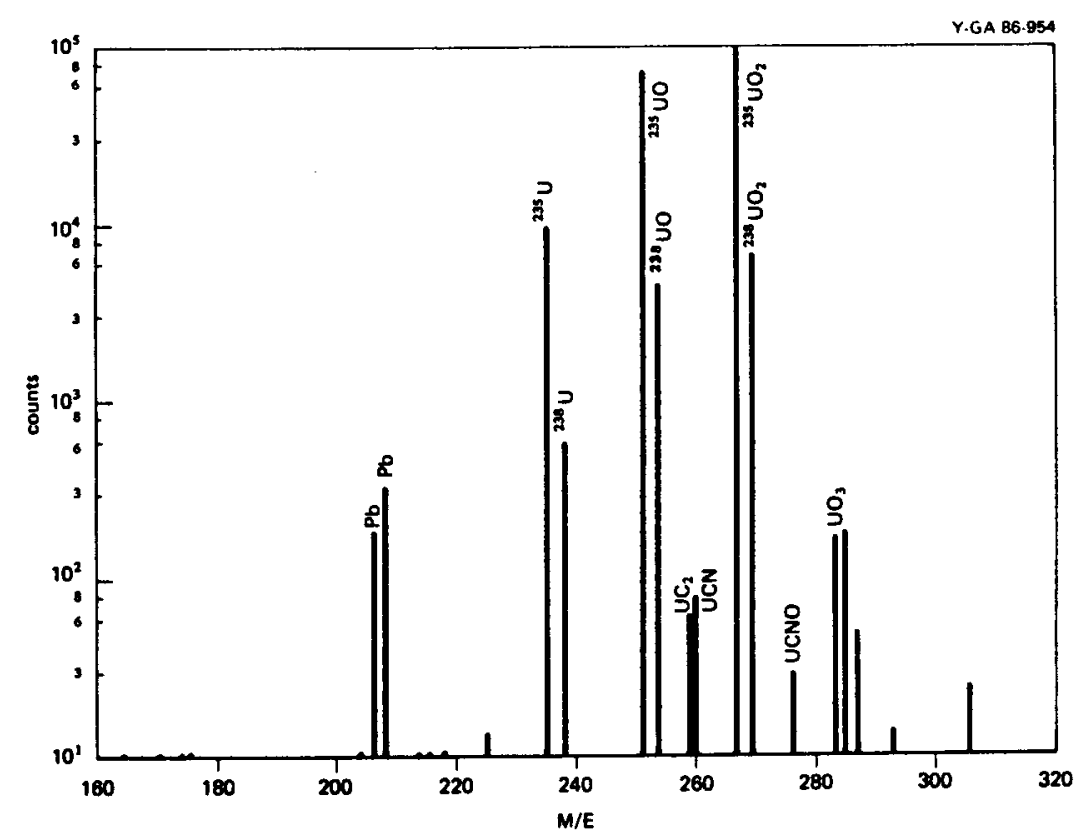

Fig. 3c. Positive mass spectrum from outer contour of part 5715, mouth area, mass range $160-320$. 


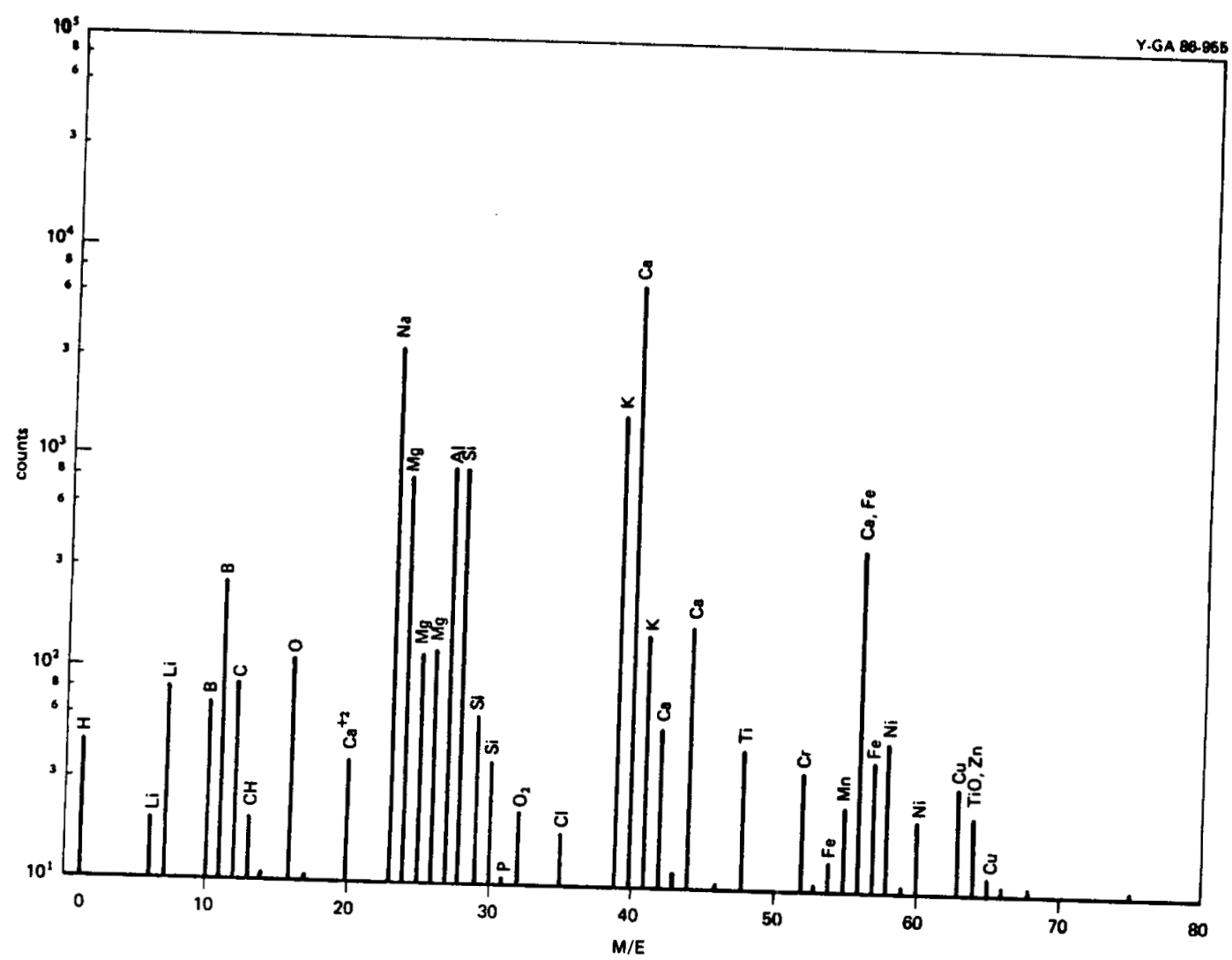
Fig. 4a. Positive mass spectrum from inner contour of part
5715, mouth area, mass range $0-80$.

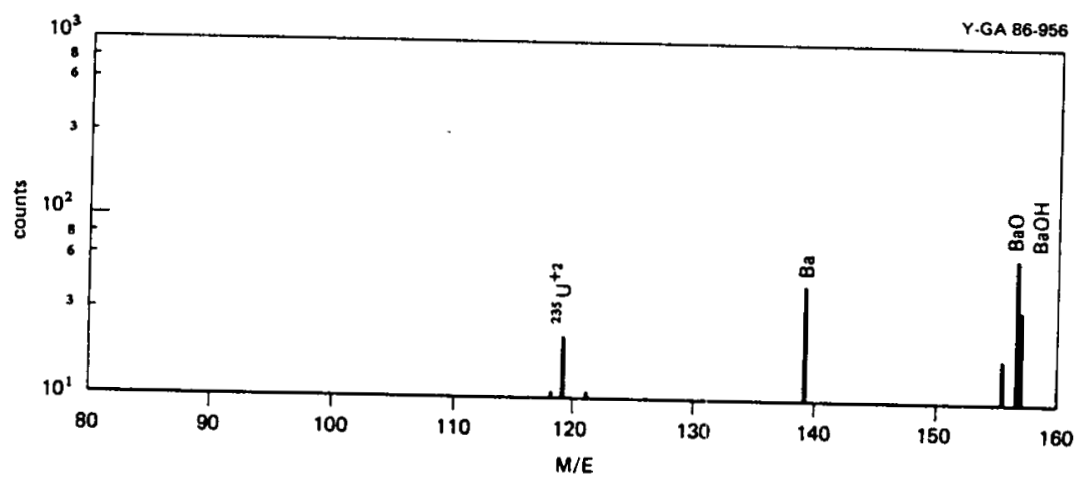

Fig. 4b. - Positive mass spectrum from inner contour of part 5715, mouth area, mass range
80-160.

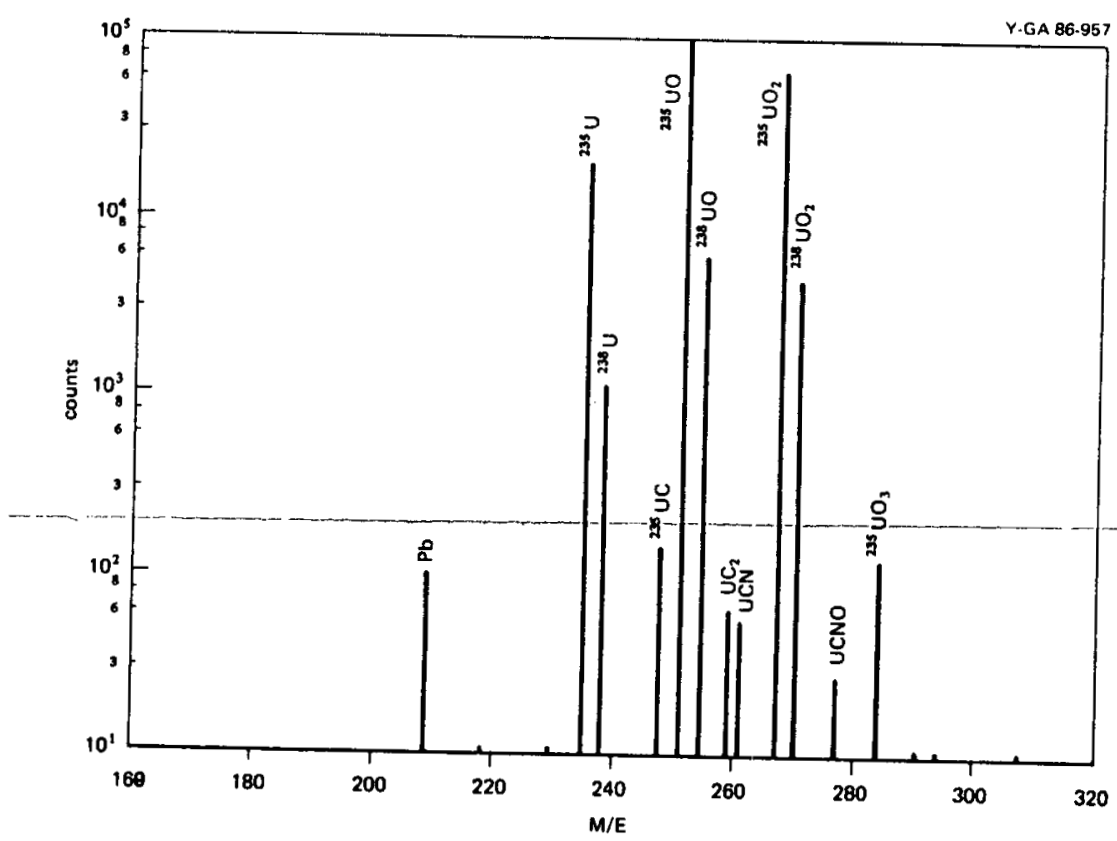

Fig. 4c. Positive mass spectrum from inner contour of part 5715, mouth area, mass range
$160-320$. 


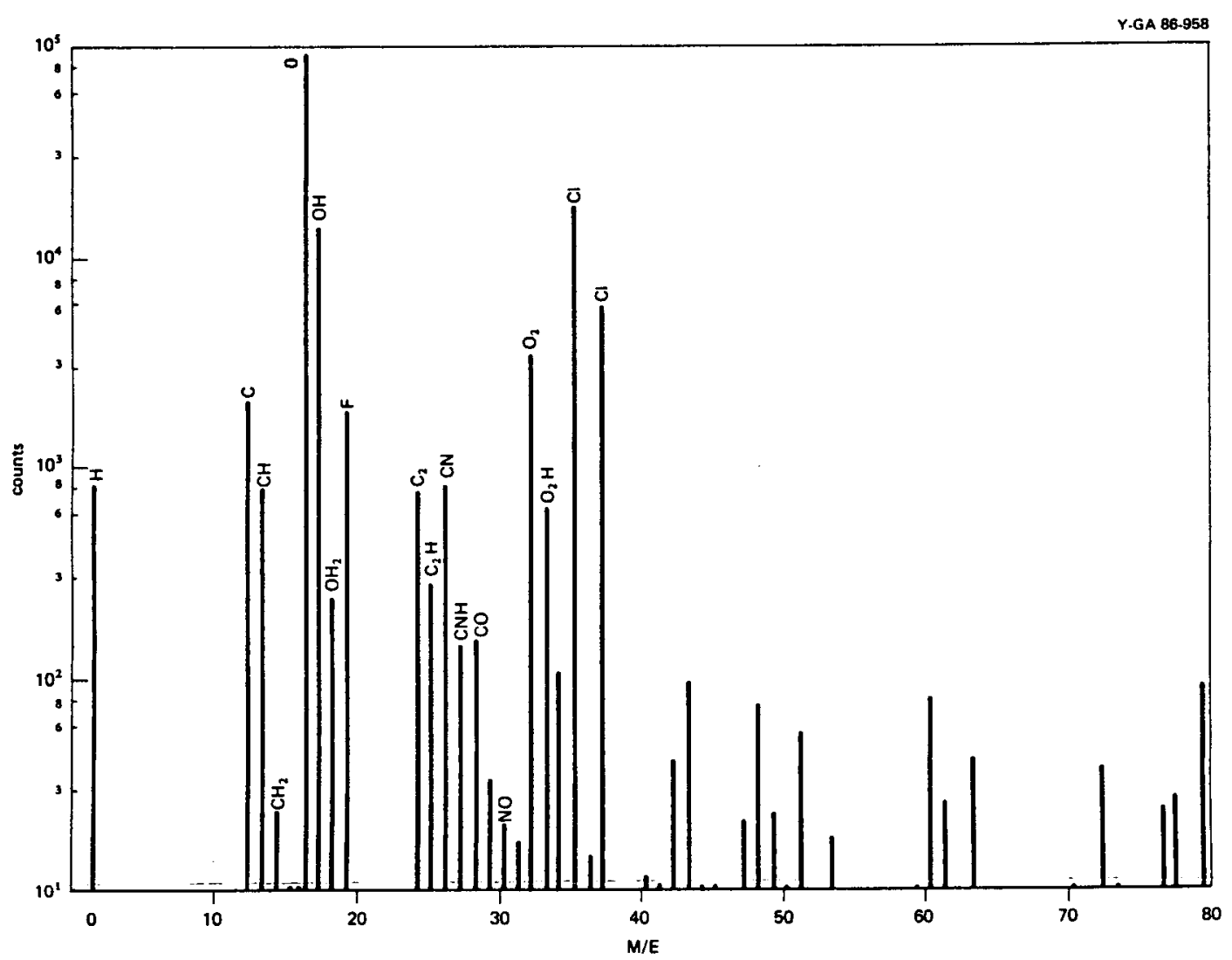

Fig. 5. Negative mass spectrum from outer contour of part 5715, mouth area.

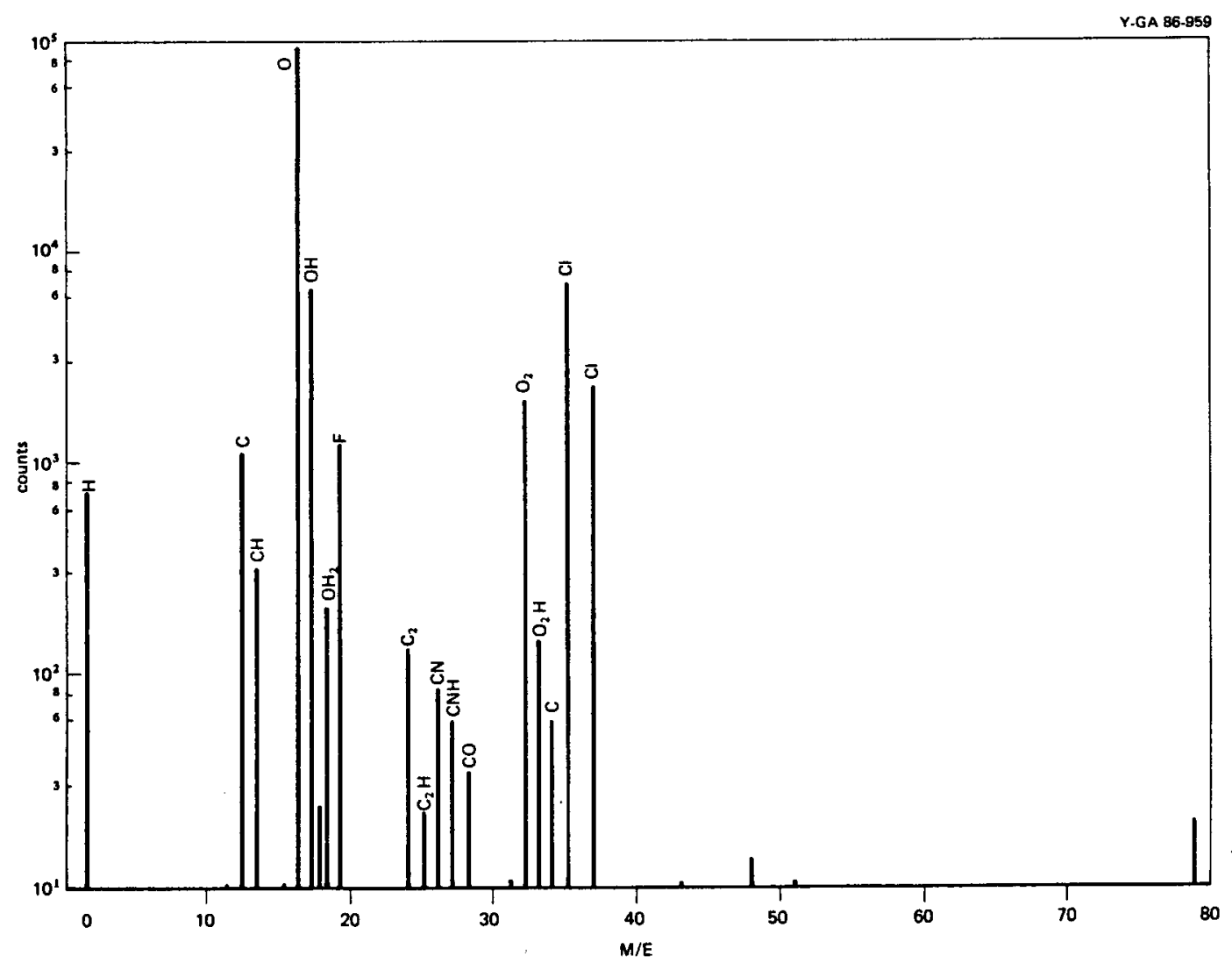

Fig. 6. Negative mass spectrum from inner contour of part 5715, mouth area. 


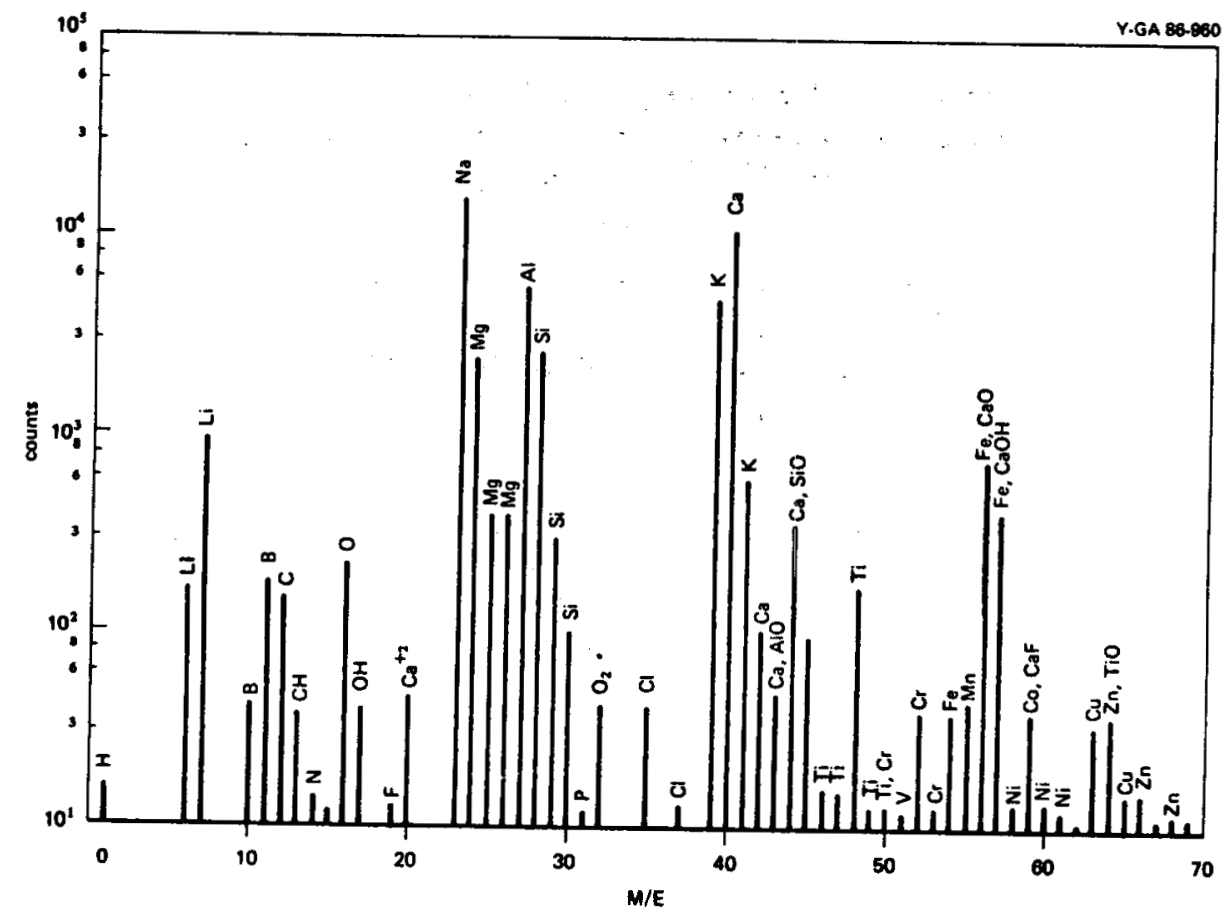

Fig. 7a. Positive mass spectrum from outer contour of part 5713, mass range 0-70.

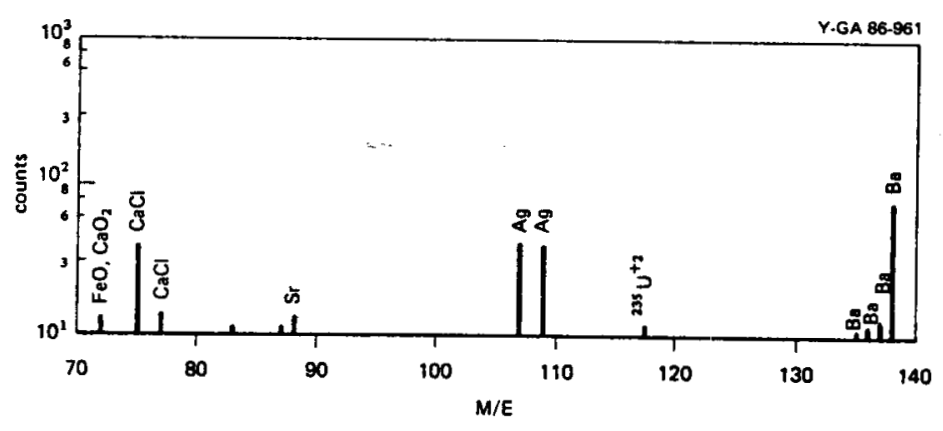

Fig. 7b. Positive mass spectrum from outer contour of part 5713, mass range 70-140.

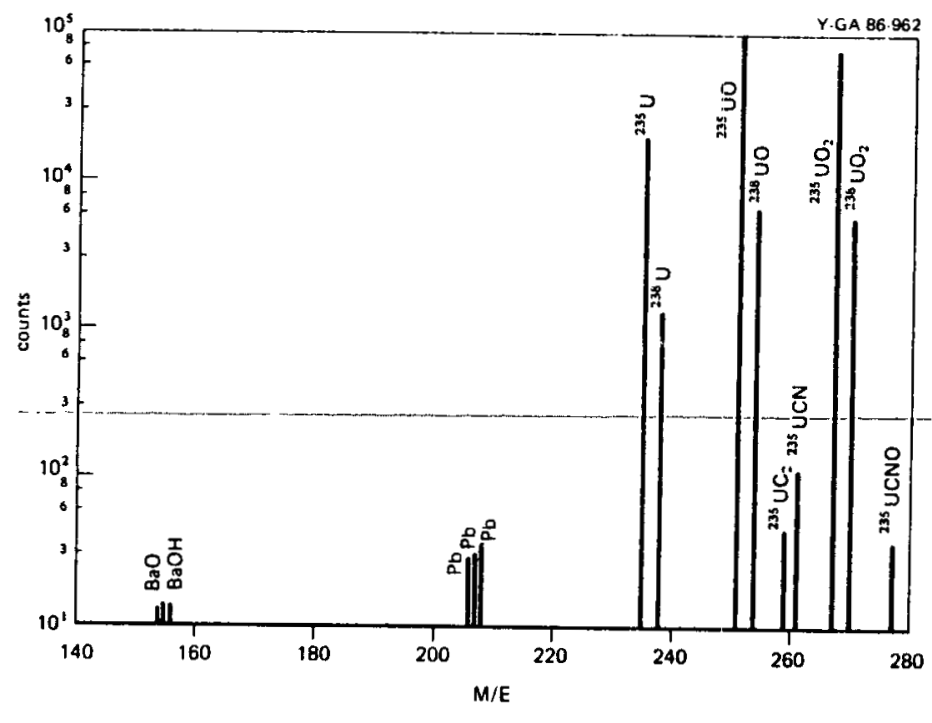

Fig. 7c. Positive mass spectrum from outer contour of part 5713, mass range 140-280. 


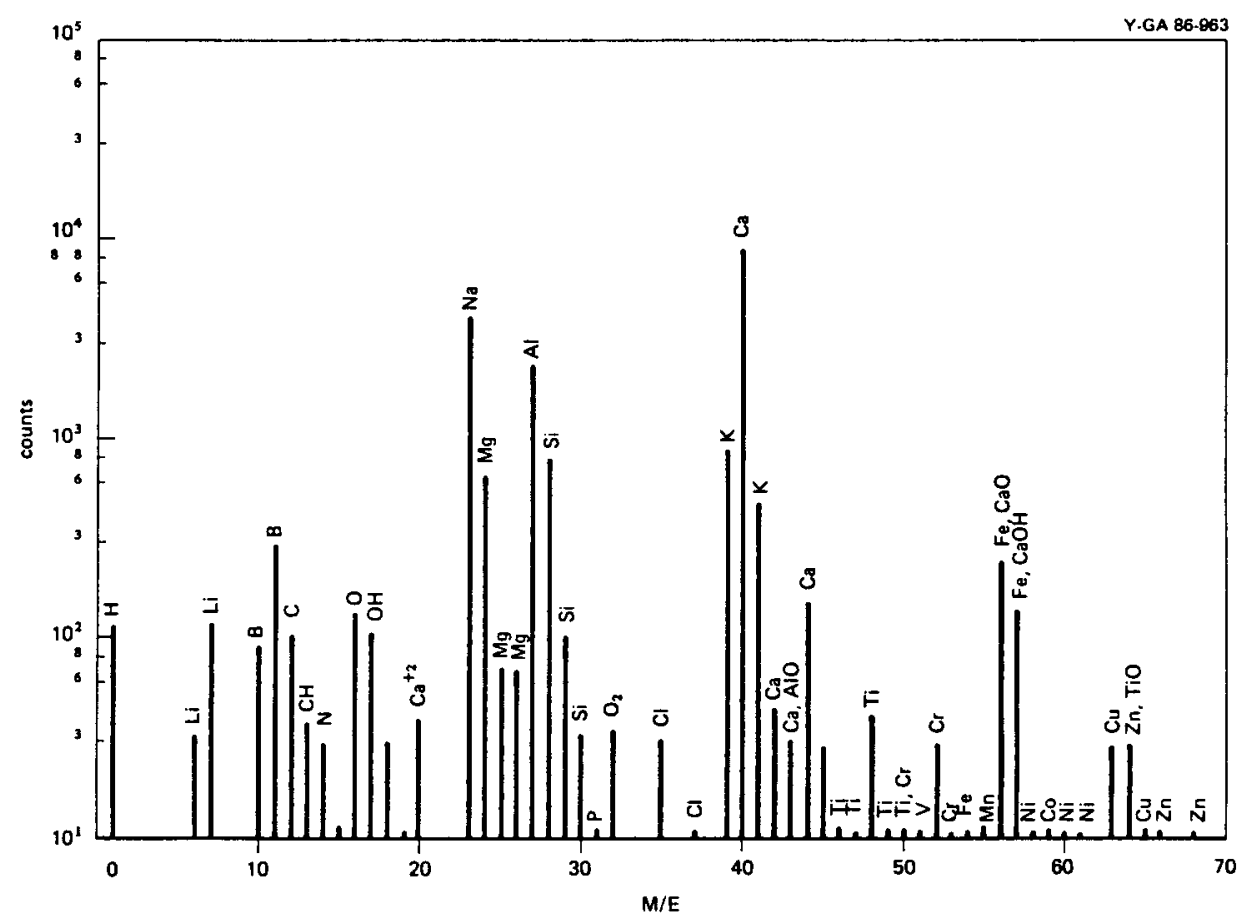

Fig. 8a. Positive mass spectrum from inner contour of part 5713, mass range $0-70$.

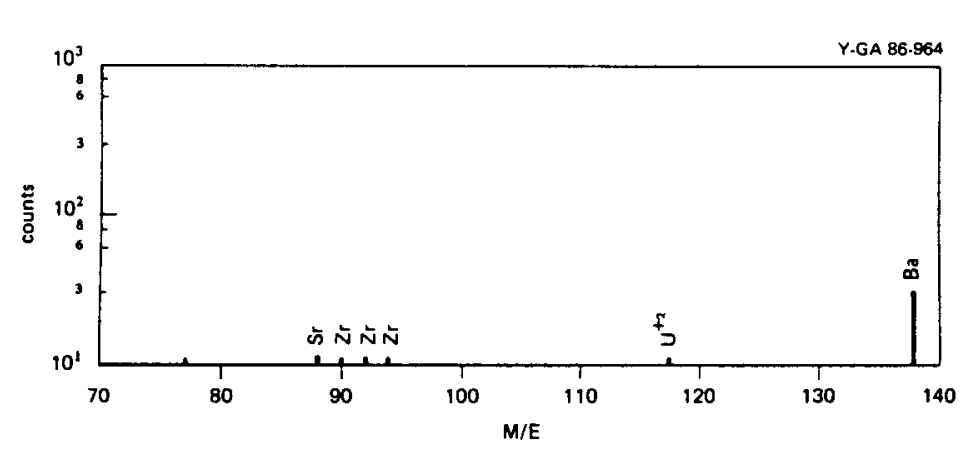

Fig. 8b. Positive mass spectrum from inner contour of part 5713, mass range 70-140.

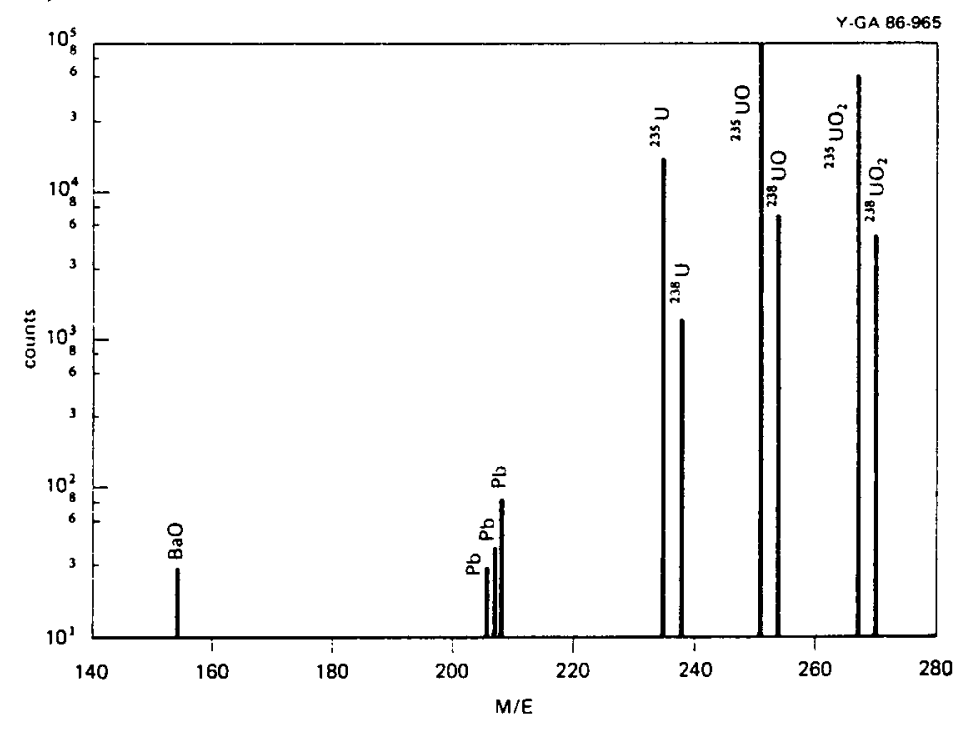

Fig. 8c. Positive mass spectrum from inner contour of part 5713, mass range 140-280. 


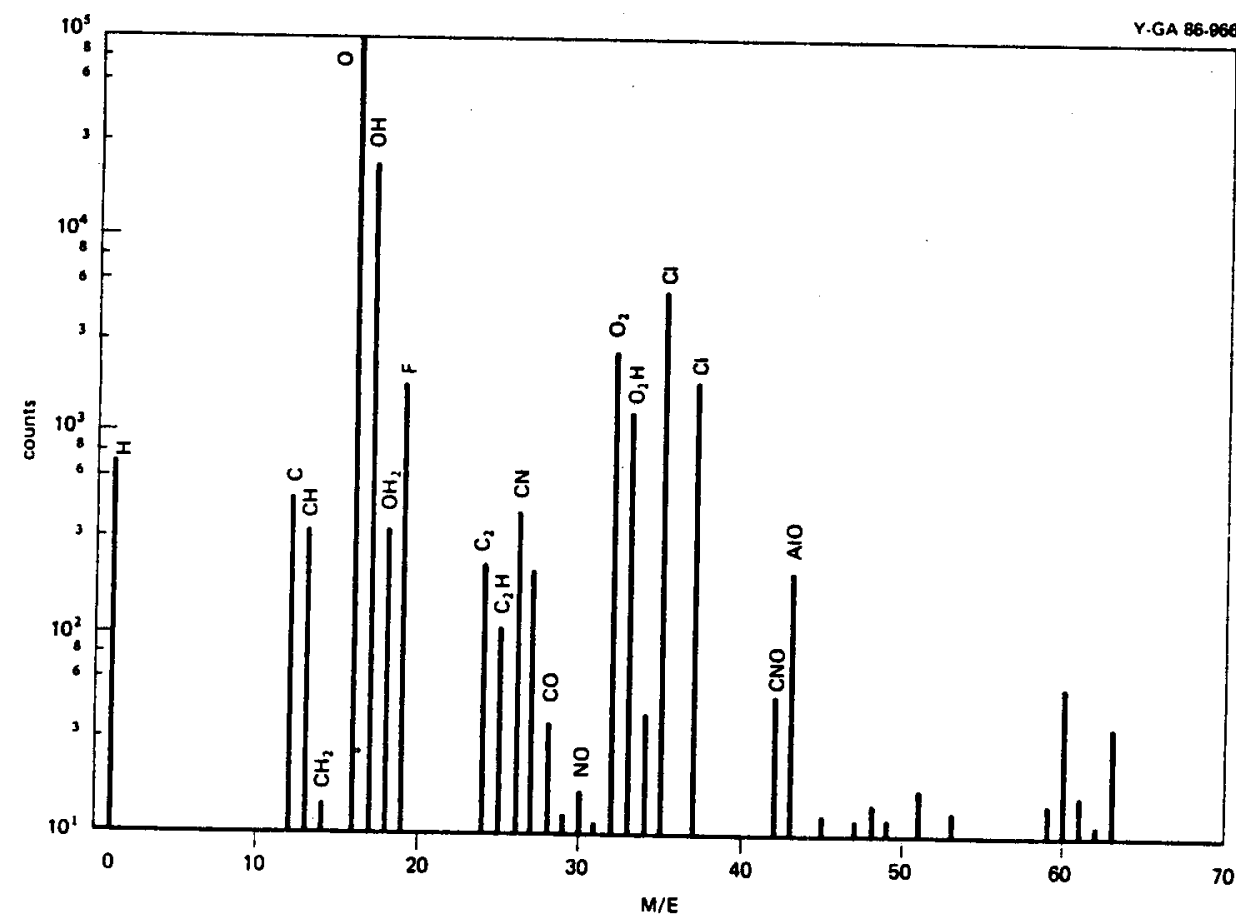

Fig. 9. Negative mass spectrum from outer contour of part 5713.

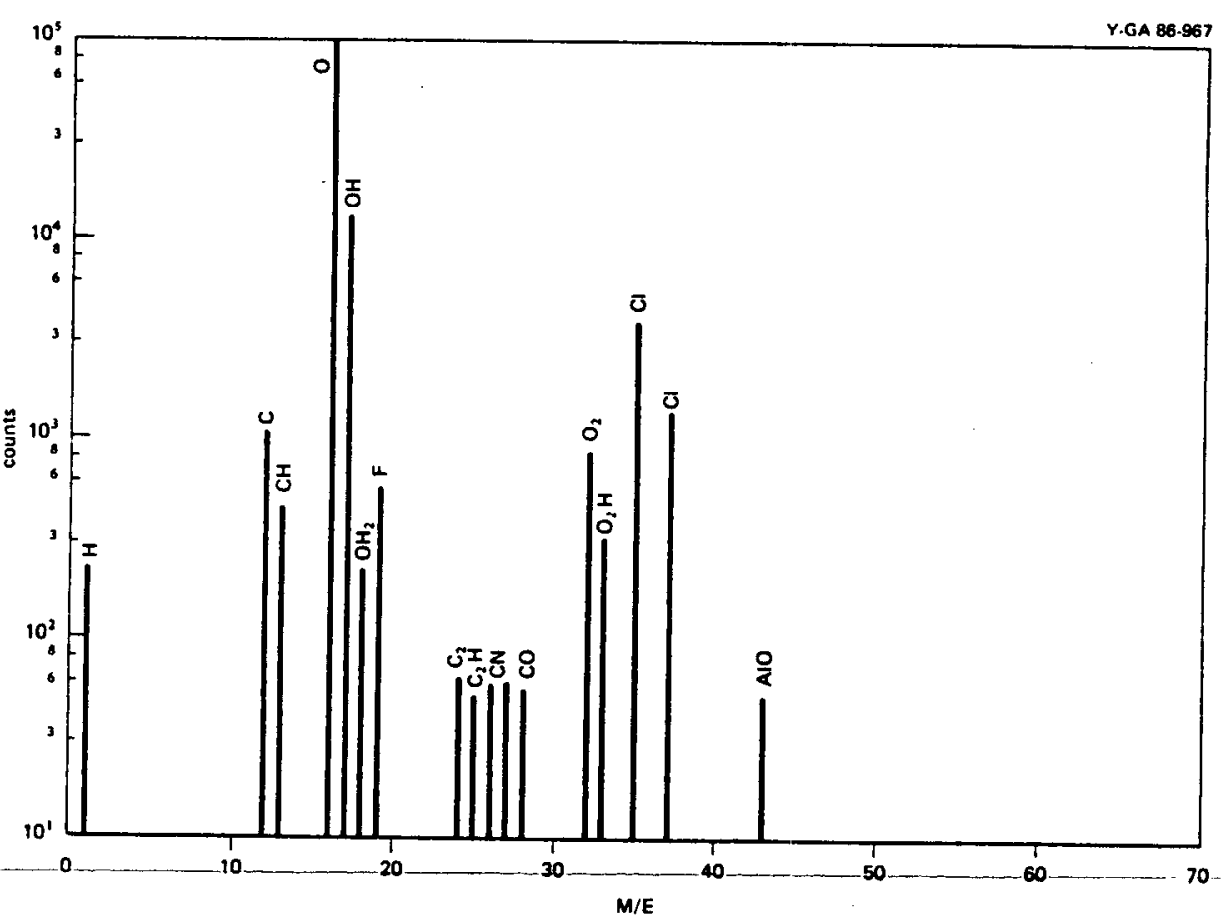

Fig. 10. Negative mass spectrum from inner contour of part 5713. 


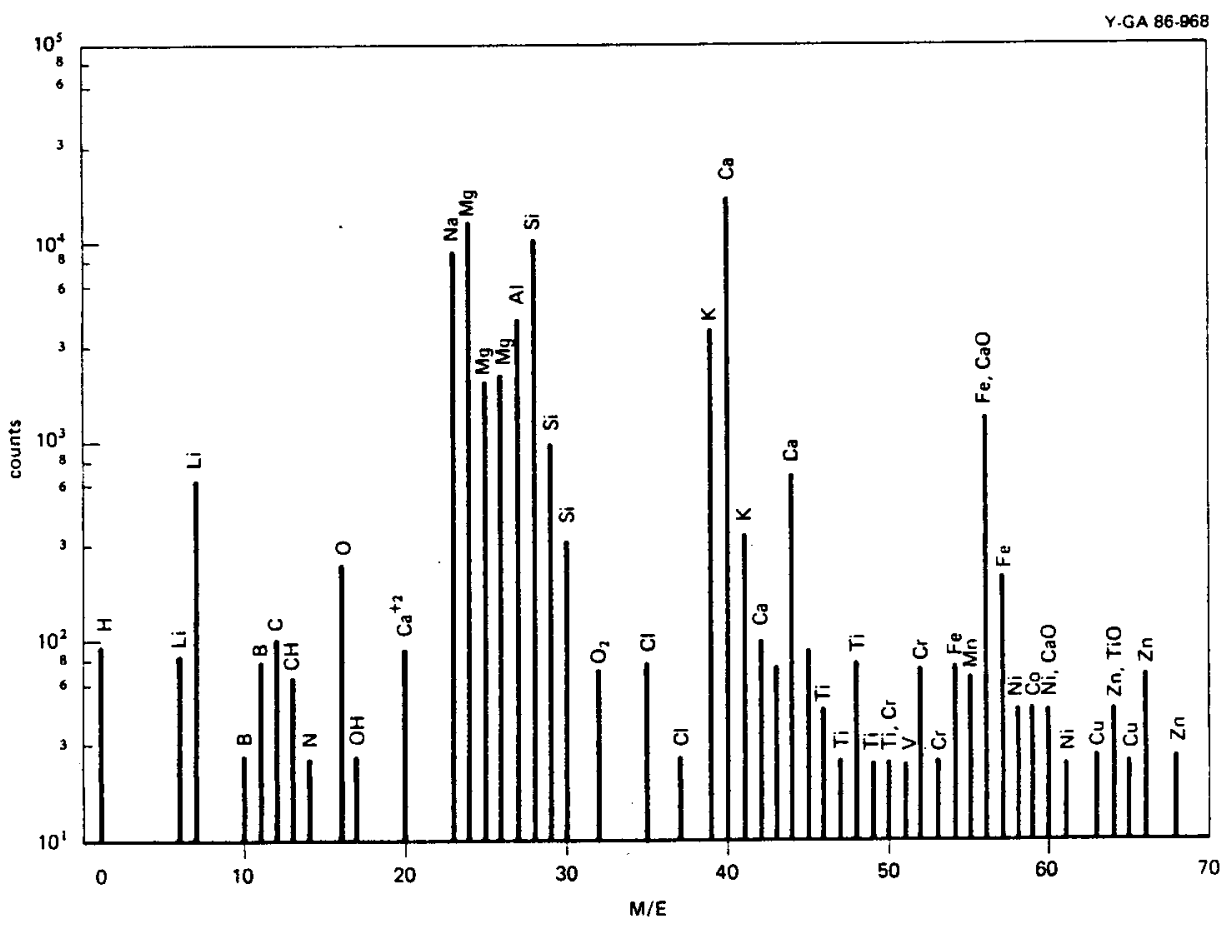

Fig. 11a. Positive mass spectrum from inner contour of part 5726, (perc machined) $45^{\circ}$ area, mass range 0-70.

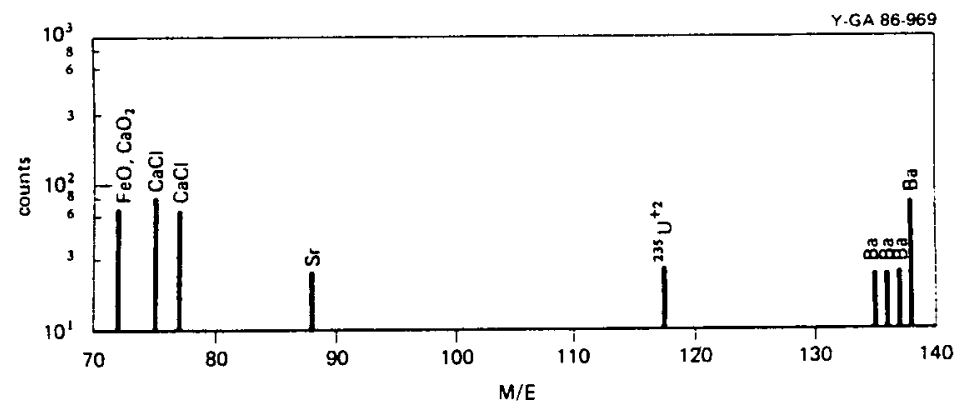

Fig. 11b. Positive secondary-ion mass spectrum from inner contour of part 5726, mass range $70-140$.

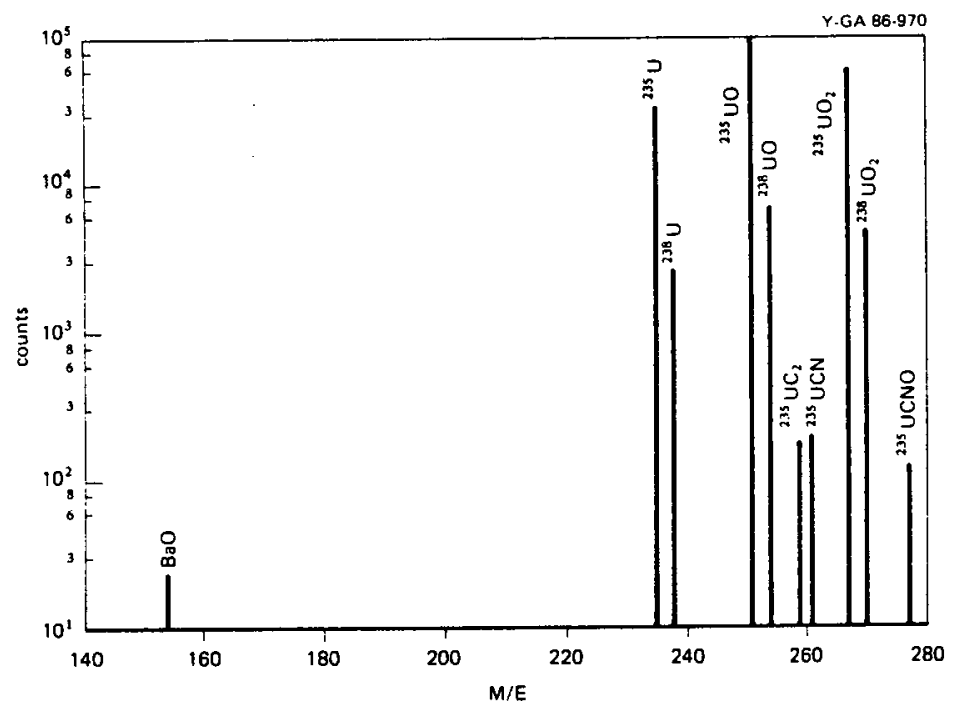

Fig. 11c. Positive mass spectrum from inner contour of part 5726, mass range 140-280. 
level is lower in this spectrum, it is not absent. Chlorine is higher, and the general level of most peaks is a little higher with some exceptions, such as lead. Figure 12 shows the negative secondary-ion spectrum from the same part 5726 surface. This surface appears to have a little more chlorine but less carbon and $\mathrm{OH}$ than its counterpart shown in Fig. 10.

All other perc-cut surfaces are similar to these and are not shown to avoid redundancy. Likewise, the boron-coolant surfaces not shown are similar to the standard treatment surfaces shown in Figs. 7 through 10. Overall, the differences in surface contaminants between the perc-machined and the boron coolant-machined surfaces are not great. Some differences observed were greater boron, carbon, and $\mathrm{OH}$ on the boron-coolant parts and greater chlorine on the perc-coolant parts.

\section{ESCA Studies}

Qualitative ESCA spectra, representative of the first five distinct surface conditions listed in Table 2, are shown in Figs. 13 through 17. All of the qualitative spectra were similar, with major photoelectron peaks from uranium, oxygen, and carbon. Also, traces or very minor peaks from calcium and sulfur were observed in all spectra. In one or two cases, sodium from the boron coolant and chlorine from the perc coolant were observed at very low levels. Low concentrations of boron, even if present, could not be distinguished because of boron's small photoelectric cross section and also because it would be obscured by a much stronger $U\left(5 p_{3 / 2}\right)$ peak, which is within a few electron volts of the main $B(1 s)$ peak.

The $O(1 s), U(4 f)$, and $C(1 s)$ spectra were obtained from the mouth, $45^{\circ}$, and pole disks representative of all seven surface conditions listed in Table 2. Little differences in the spectra were observed among mouth, $45^{\circ}$, and pole. All of the spectra from the same photoelectron level are similar. There is some variation in intensity of the peaks, but consistency of the binding energies indicates that the same species are present on all surfaces. The $O(1 \mathrm{~s})$ spectra show at least two distinct peaks that can be deconvoluted, using a Gaussian deconvolution routine, into peaks with binding energies of $531.6 \pm 0.15$ and $529.4 \pm 0.06 \mathrm{eV}( \pm 1 \sigma)$ with a full width at half maximum (FWHM) $( \pm 1 \sigma)$ of $2.97 \pm 0.16$ and $1.67 \pm 0.03 \mathrm{eV}$, respectively. Figures 18 and 19 compare the $O(1 \mathrm{~s})$ spectra on the boron coolant-machined and perc-machined disks, respectively, after the standard treatment (45 d) and after 6 months of storage $(225 \mathrm{~d})$. As storage time increases, the $O(1 \mathrm{~s})$ low-binding energy (LBE) peak decreases and the $O(1 \mathrm{~s})$ high-binding energy (HBE) peak increases for both coolants, but the changes are greater for the perc coolant. The $O(1 \mathrm{~s})$ LBE peak is associated with oxidic-type oxygen, while the $O(1 \mathrm{~s})$ HBE peak is attributed, tentatively, by most investigators to be a hydroxylic-type oxygen ${ }^{1,2}$ and dependent on the surface preparation and history. 


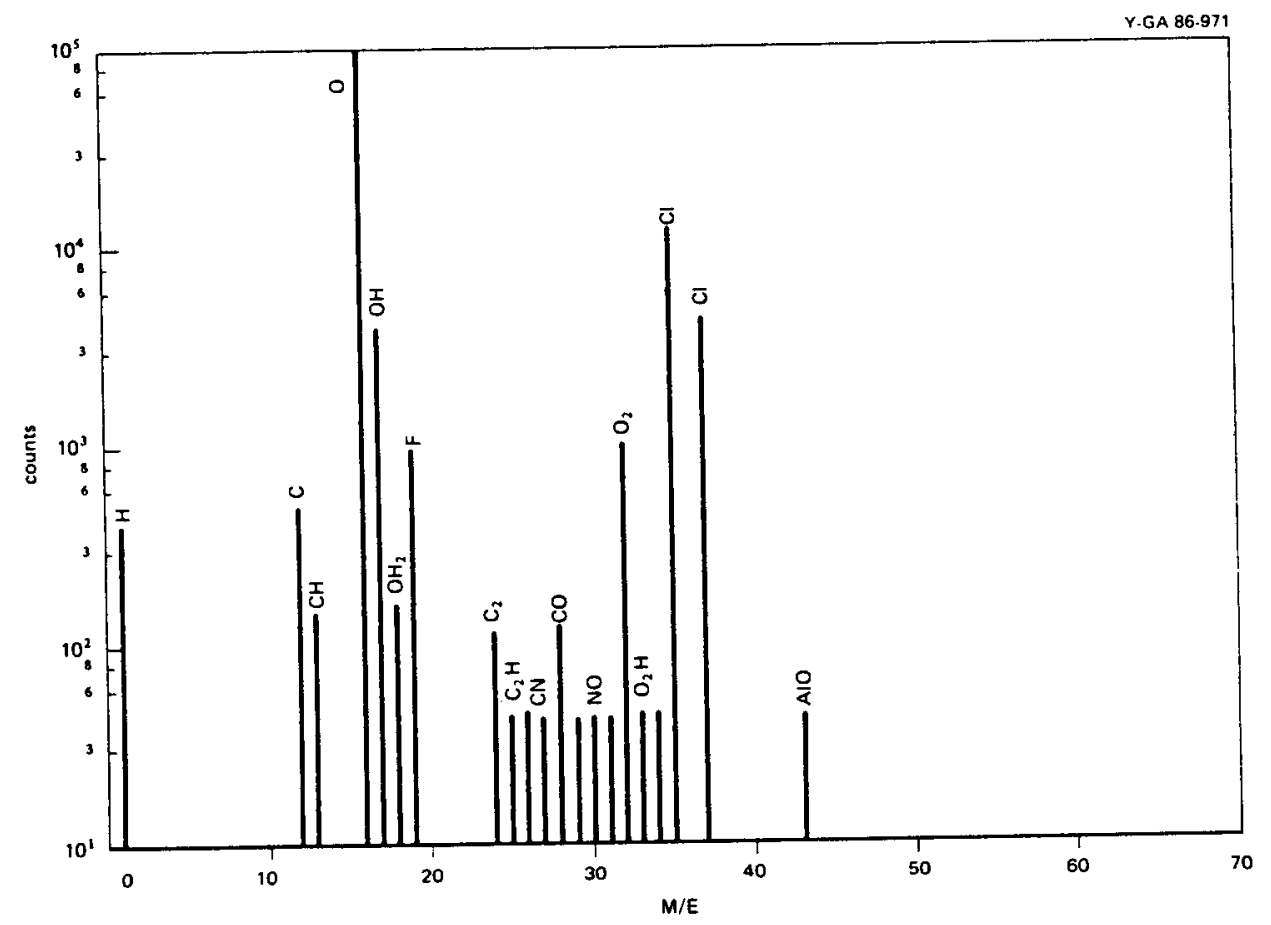

Fig. 12. Negative mass spectrum from inner contour of part 5726, (perc machined) $45^{\circ}$ area.

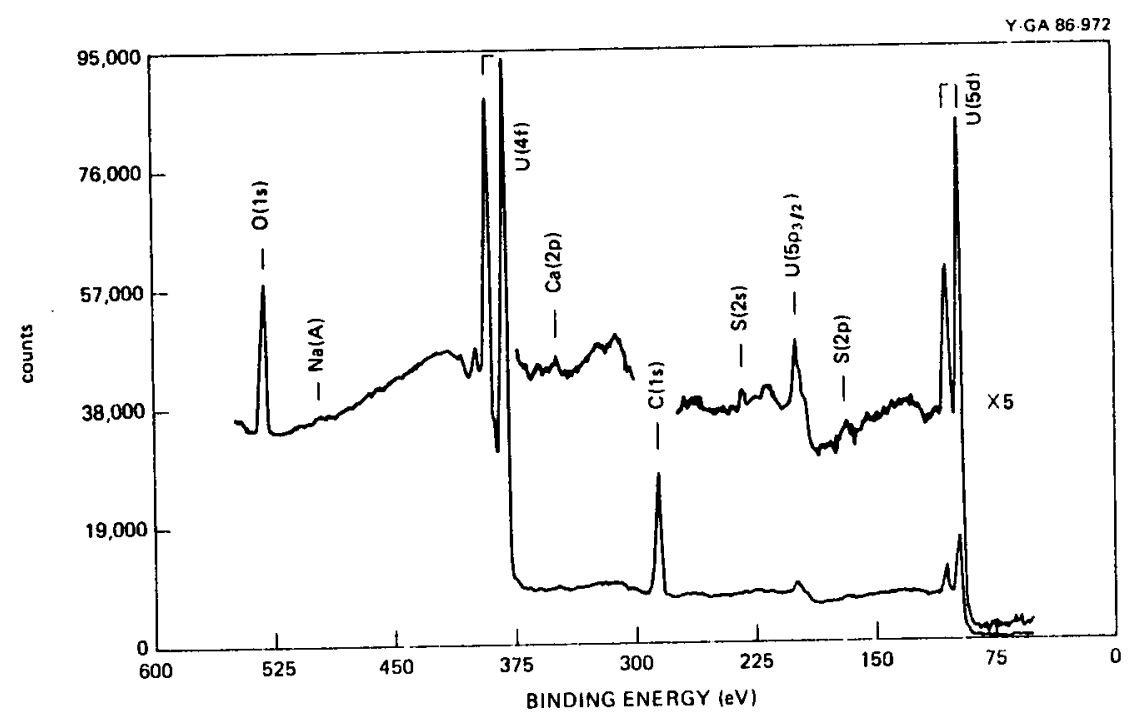

Fig. 13. Qualitative ESCA spectrum of enriched uranium machined with boron coolantlike Rocky Flats test parts. 


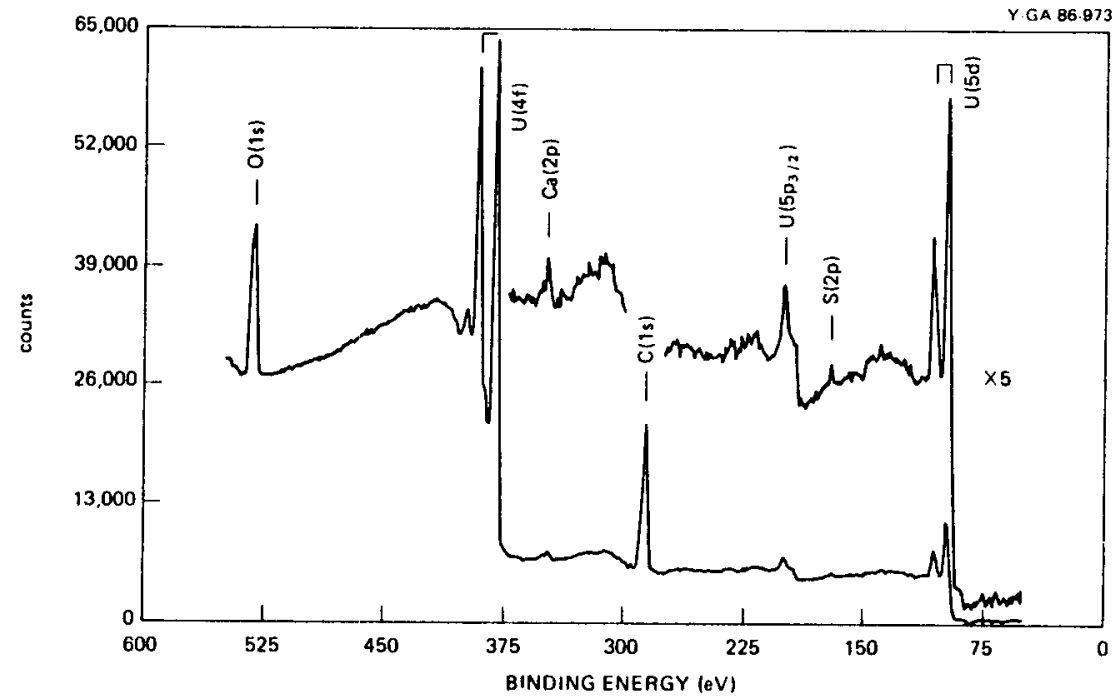

Fig. 14. Qualitative ESCA spectrum of enriched uranium machined with boron coolant-standard treatment.

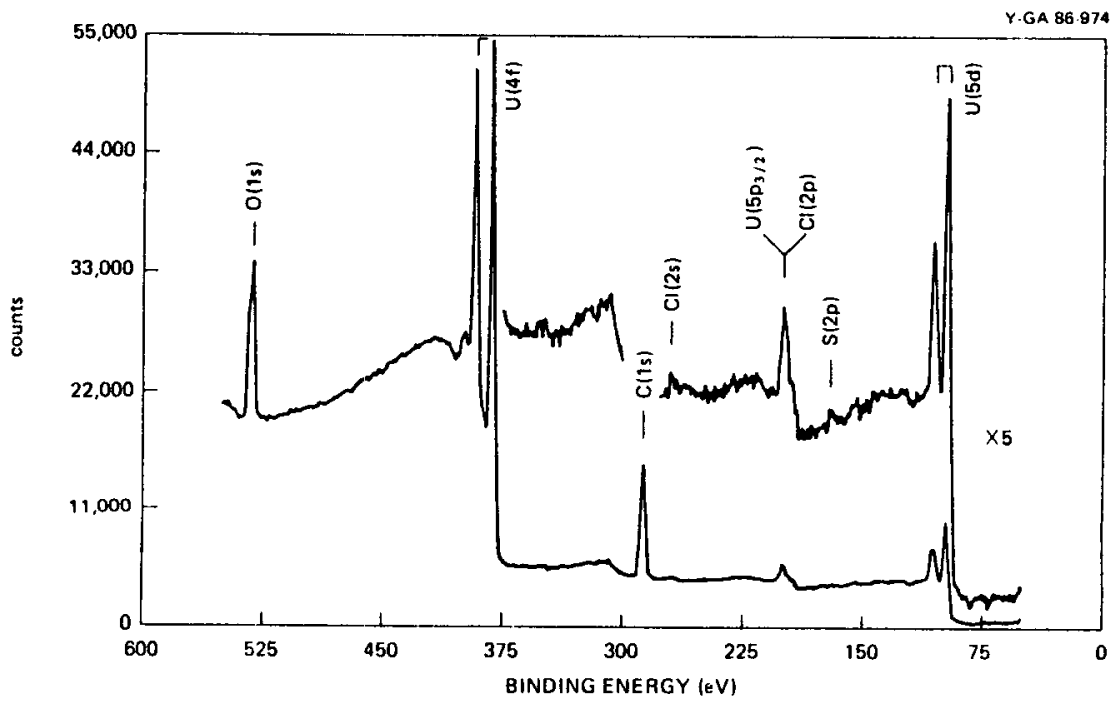

Fig. 15. Qualitative ESCA spectrum of enriched uranium machined with perc coolant-standard treatment. 


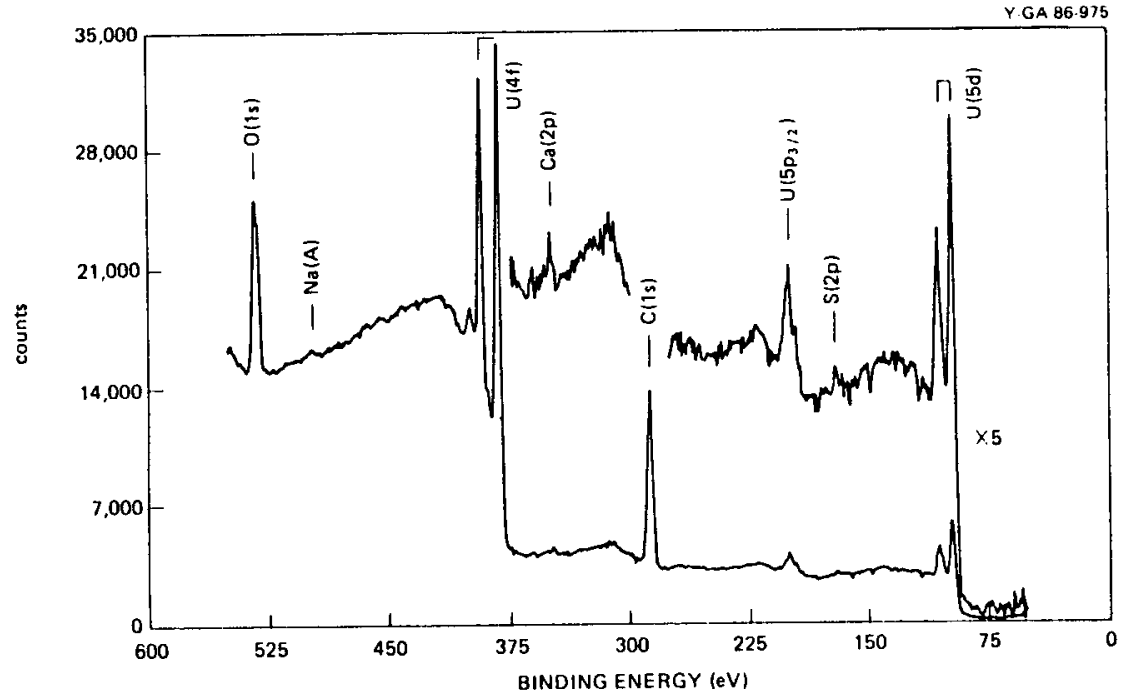

Fig. 16. Qualitative ESCA spectrum of enriched uranium machined with boron coolant-additional month storage in Rocky Flats bag.

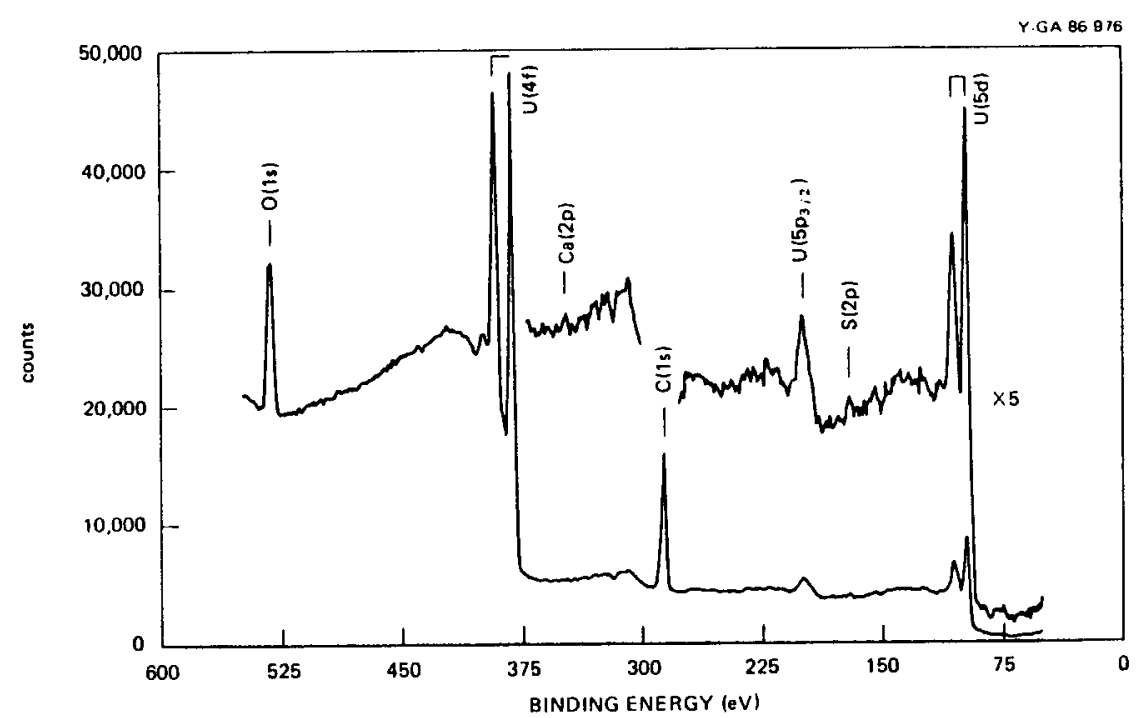

Fig. 17. Qualitative ESCA spectrum of enriched uranium machined with perc coolant-additional month storage in Rocky Flats bag. 


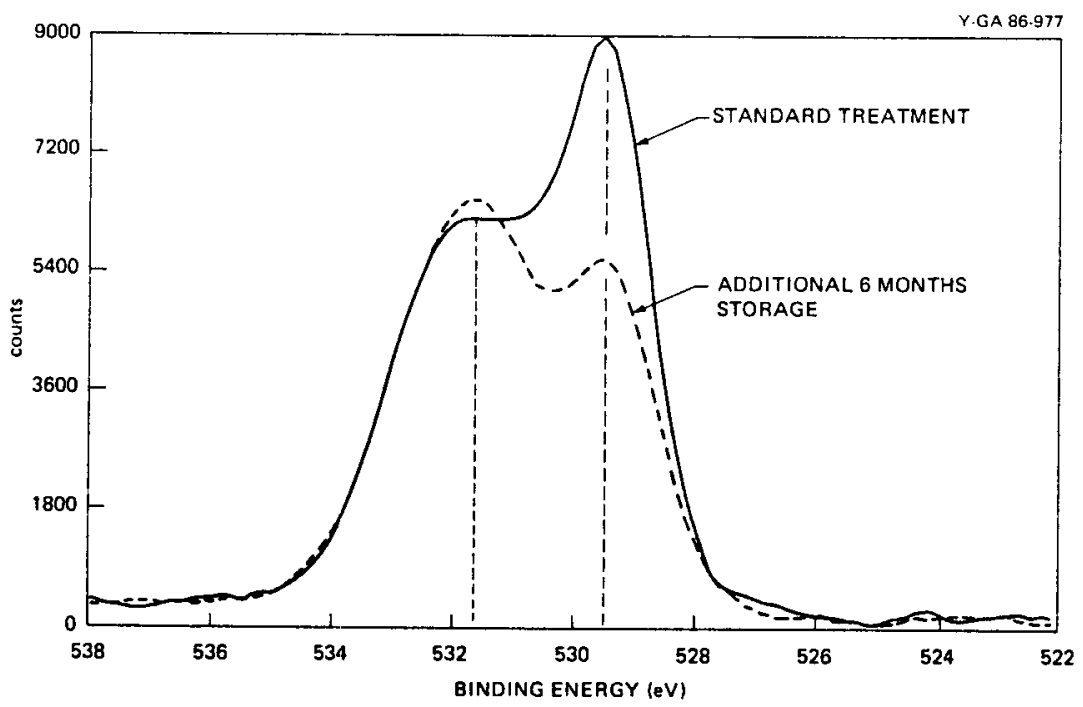

Fig. 18. O(1s) spectra from enriched uranium machined with boron coolant (pole position).

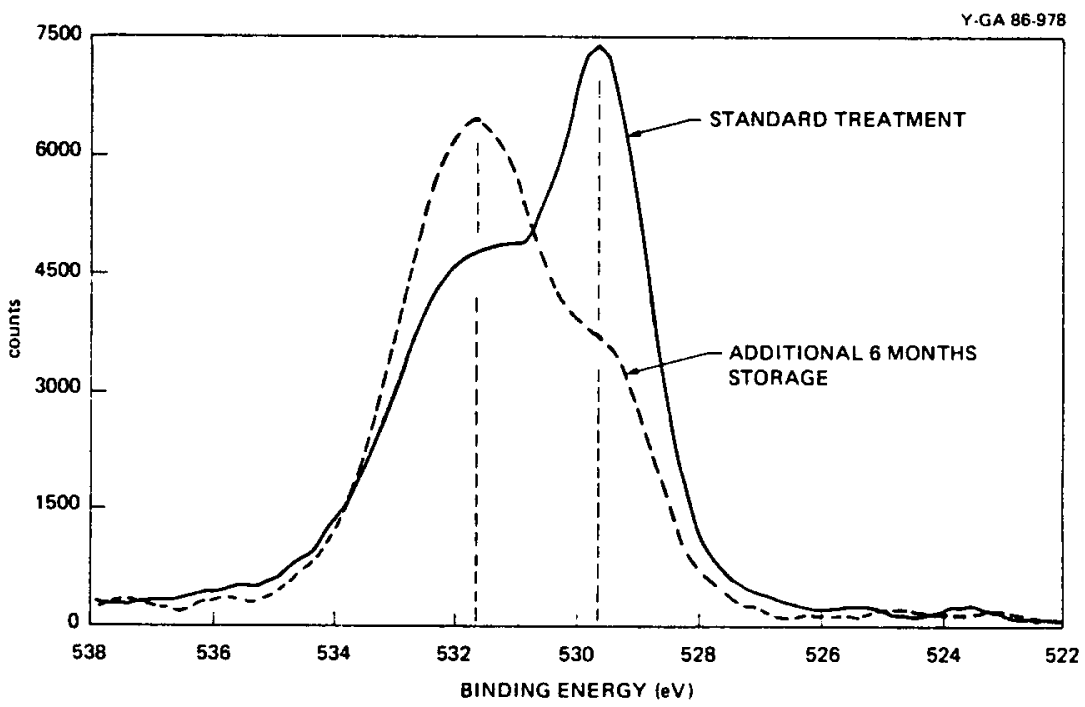

Fig. 19. O(1s) spectra from enriched uranium machined with perc coolant (pole position). 
The binding energies of the $U(4 f)$ doublet are $390.4 \pm 0.13$ and $379.6 \pm 0.13 \mathrm{eV}$ with FWHM of $2.28 \pm 0.11$ and $2.24 \pm 0.09 \mathrm{eV}$. Figures 20 and 21 compare the $U(4 f)$ spectra on the boron coolant-machined and perc-machined disks, respectively, after the standard treatment and after 6 months of storage. The $U(4 f)$ binding energies and the shake-up satellite structure on the HBE of the main peaks indicate uranium in the +4 oxidation state. As storage time increases, these spectra show a decrease in the $U(4 f)$ peaks and a shift toward higher binding energies, indicating a change toward higher oxidation states.

All binding energies are referenced to the $C(1 \mathrm{~s})$ level at $284.6 \mathrm{eV}$ and are the averages of 27 values. The $C(1 \mathrm{~s})$ peaks for the boron and perc coolants are shown in Figs. 22 and 23, respectively. Because little change in the carbon spectra is seen with time, these figures illustrate the intensity changes that may be observed at different locations (pole, $45^{\circ}$, equator) on the parts. Table 6 gives atomic concentration ratios that show trends in the sample surface behavior. The relatively low standard deviations in the atomic ratio calculations show the consistency of the analyses within a particular surface condition. These data show several trends:

1. The $O(1 s) / U(4 f)$ ratios for the boron-cut parts and the perc-cut parts are not significantly different.

2. The $O(1 s) / U(4 f)$ ratio increases with storage time for both coolantcut parts equally.

3. The $C(1 s) / U(4 f)$ ratios for the boron-cut and for the perc-cut parts increase with storage time and are not significantly different.

4. The $O(1 \mathrm{~s}) \mathrm{HBE} / \mathrm{O}(1 \mathrm{~s}) \mathrm{LBE}$ ratio increases with storage time for both coolants, but the perc-cut ratio increases more than that for the boron-cut parts for storage times exceeding $64 \mathrm{~d}$.

These trends were analyzed statistically using the $F$ test. This test indicated that the increases in $O(1 s) / U(4 f), C(1 s) / U(4 f)$, and $O(1 s)$ $\mathrm{HBE} / \mathrm{O}(1 \mathrm{~s})$ LBE ratios were linear with respect to storage time. Differences between the three sample areas from either boron-cut or perc-cut parts were not statistically significant (see Appendix).

\section{DETERMINATION OF OXIDE CORROSION LAYER THICKNESS}

The IMMA was employed to determine the thickness or depth of the oxide corrosion layers that formed on the enriched uranium surfaces after each of the seven different conditions, as listed in Table 2 . The layers were measured by sputtering at least two 31 - by $39-\mu \mathrm{m}$ rectangles on the surface of the IC and the $O C$ of one coupon each from the mouth, $45^{\circ}$, and pole areas from each part. Examples of the secondary-ion depth profiles of $\mathrm{O}^{-}$that were generated are shown in Figs. 24 and 25. Figure 24 shows a profile from part 5692 (standard treatment, boron coolant) with a relatively thin oxide, and Fig. 25 shows a profile from 


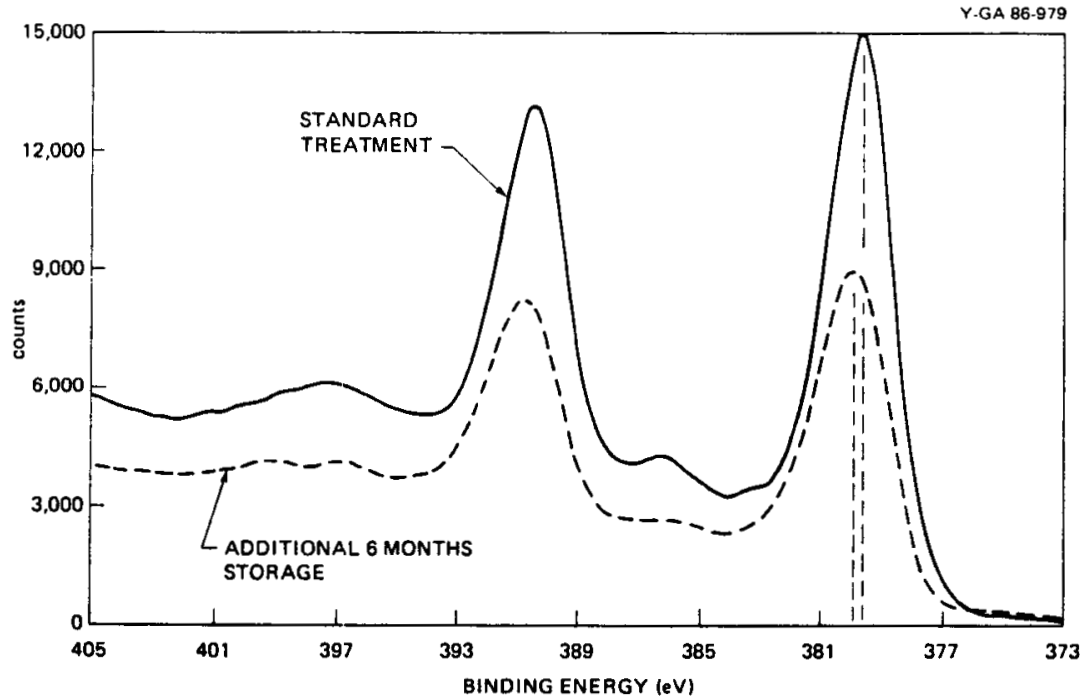

Fig. 20. U(4f) spectra from enriched uranium machined with boron coolant (pole position).

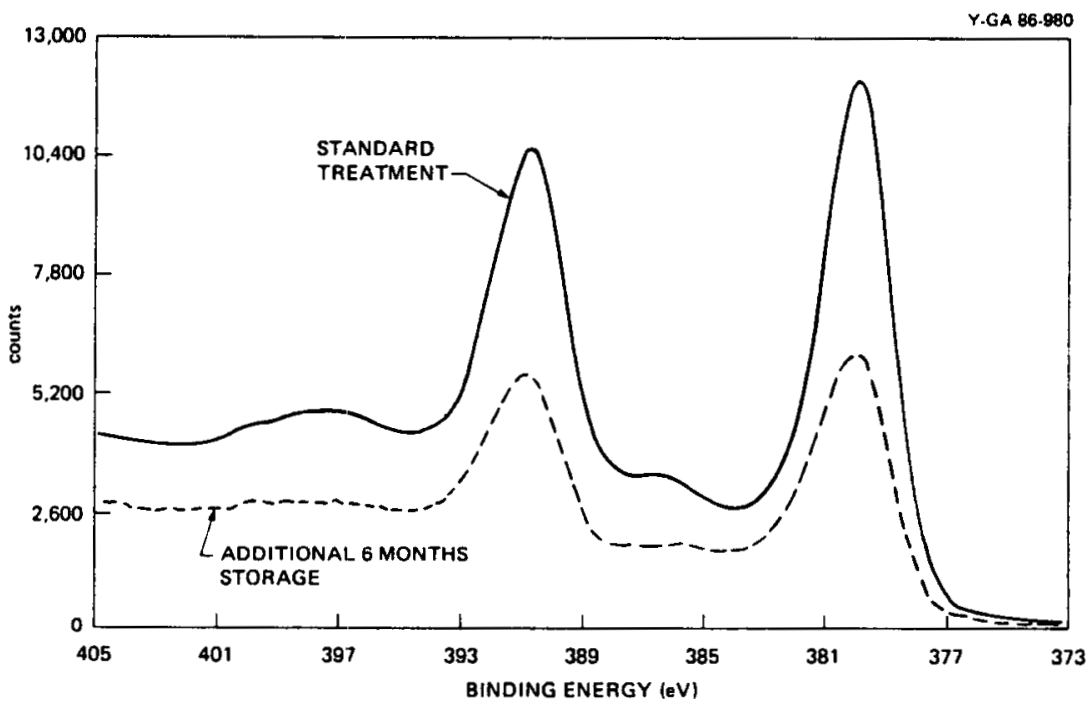

Fig. 21. U(4f) spectra from enriched uranium machined with perc coolant (pole position). 


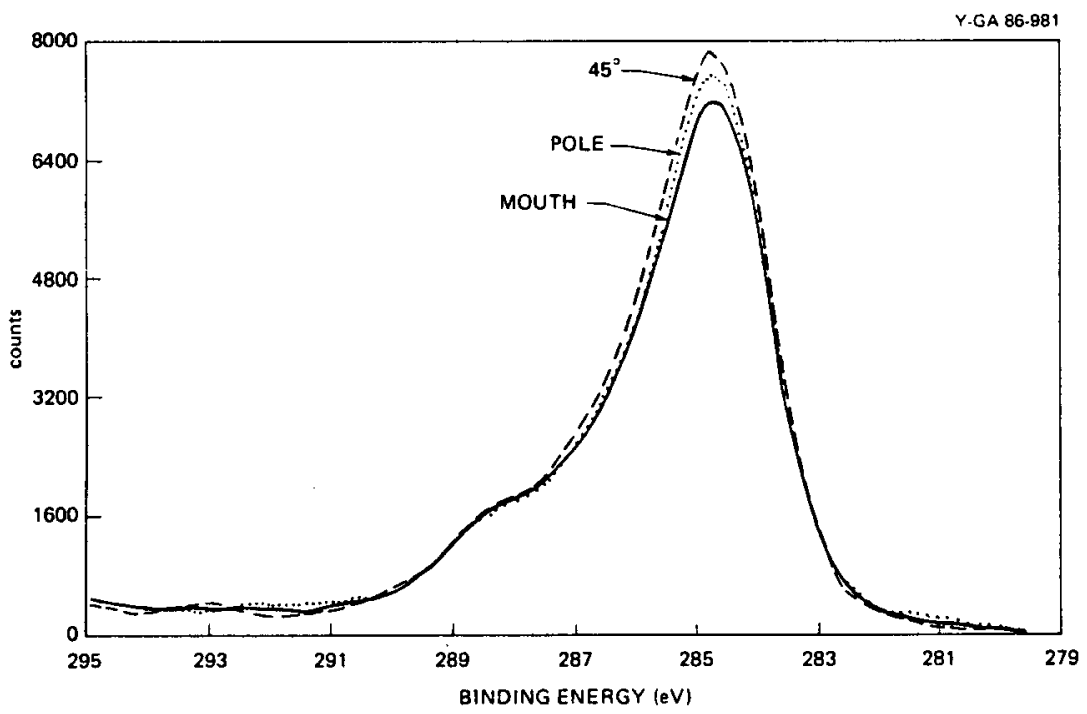

Fig. 22. C(1s) spectra from enriched uranium machined with boron coolant-additional 6 months storage in Rocky Flats bag.

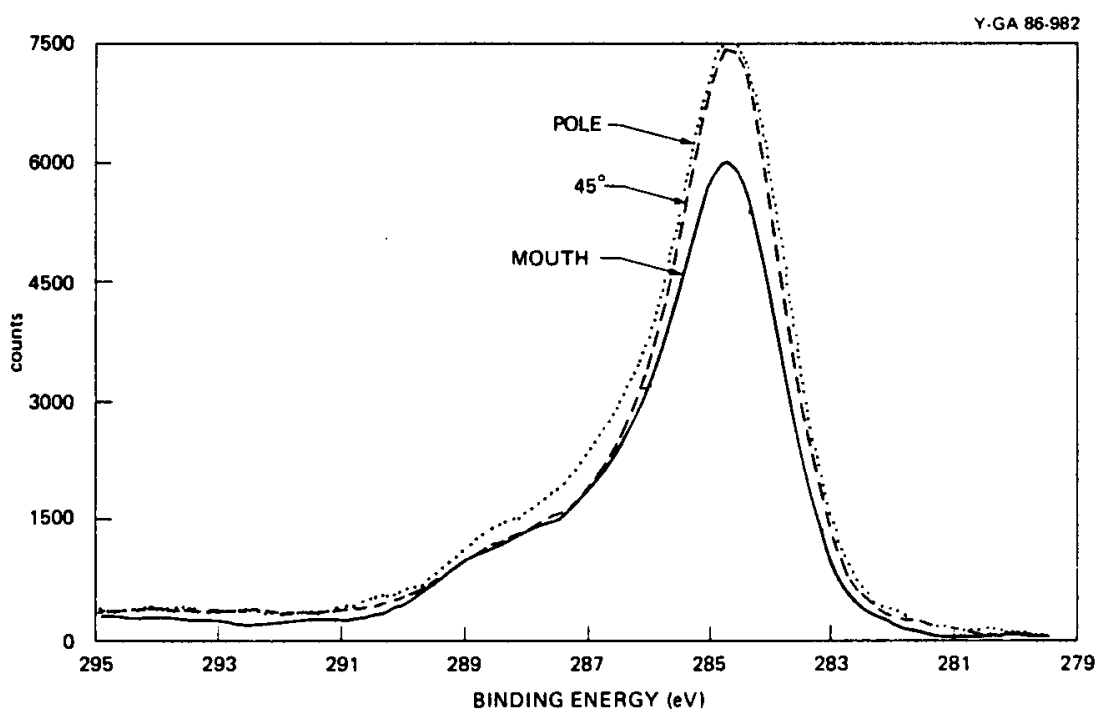

Fig. 23. C(1s) spectra from enriched uranium machined in perc coolant-additional 6 months storage in Rocky Flats bag. 
Table 6. Summary of calculated atomic ratios from ESCA determinations of relative atomic concentrations of oxygen, uranium, and carbon on the boron- and perc coolant-machined surfaces of enriched uranium

\begin{tabular}{|c|c|c|c|}
\hline $\begin{array}{l}\text { Days after } \\
\text { machining }\end{array}$ & $\frac{O(1 s) H B E}{O(1 s) L B E}$ & $\frac{O(1 s)}{U(4 f)}$ & $\frac{C(1 s)}{U(4 f)}$ \\
\hline \multicolumn{4}{|c|}{ Boron coolant } \\
\hline $\begin{array}{r}30 \\
45 \\
75 \\
225\end{array}$ & $\begin{array}{l}1.34 \pm 0.11 \\
1.40 \pm 0.15 \\
1.94 \pm 0.26 \\
3.64 \pm 1.39\end{array}$ & $\begin{array}{l}3.08 \pm 0.47 \\
3.60 \pm 0.27 \\
4.10 \pm 0.32 \\
6.05 \pm 1.10\end{array}$ & $\begin{array}{r}5.42 \pm 0.35 \\
5.45 \pm 0.67 \\
6.88 \pm 0.54 \\
10.97 \pm 2.75\end{array}$ \\
\hline \multicolumn{4}{|c|}{ Perc coolant } \\
\hline $\begin{array}{r}45 \\
75 \\
225\end{array}$ & $\begin{array}{l}1.44 \pm 0.18 \\
1.62 \pm 0.19 \\
6.10 \pm 1.52\end{array}$ & $\begin{array}{l}3.43 \pm 0.09 \\
3.70 \pm 0.29 \\
6.47 \pm 0.70\end{array}$ & $\begin{array}{r}4.32 \pm 0.45 \\
5.23 \pm 0.48 \\
14.11 \pm 3.87\end{array}$ \\
\hline
\end{tabular}

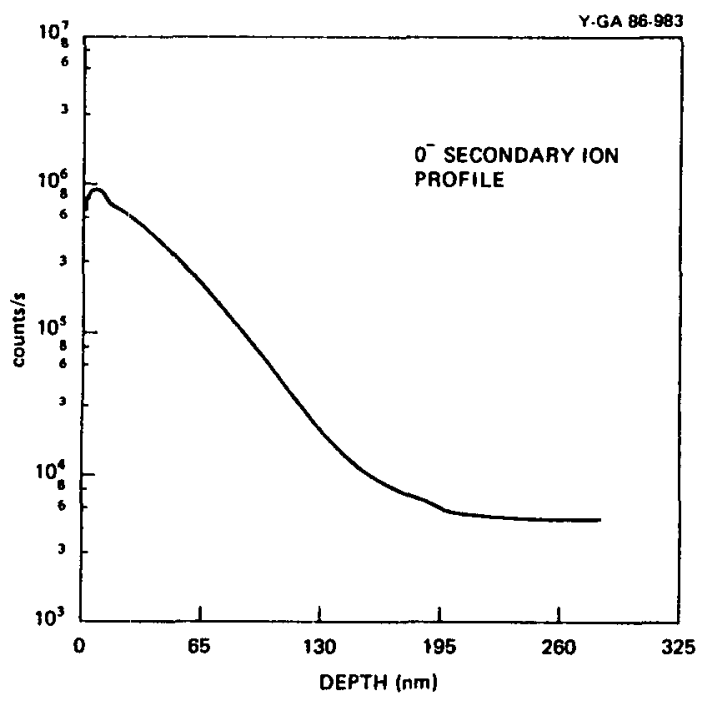

Fig. 24. Oxygen depth profile on standard treatment, sample 5692, boron coolant. 


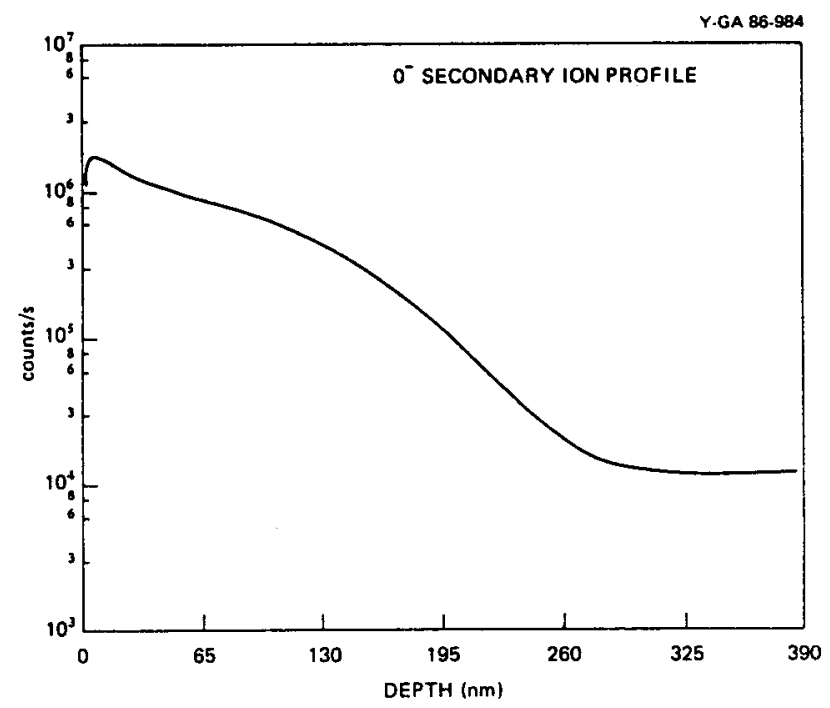

Fig. 25. Oxygen depth profile on standard plus 1 month storage, sample 5730, perc coolant.

part 5730 (perc coolant) which was stored for 1 month in a Rocky Flats bag after final processing. These profiles are of typical areas on these samples. The oxide depth measurements were calibrated by measuring sputtered craters with a surface profiler and by comparing them with ion implantation profiles determined by a nuclear reaction method.

Statistical analyses of variance (see Appendix) indicated that there are statistically significant differences in oxide depths at various locations and between the perc and boron coolant-machined shown graphically in Figs. 26 and A.4. The numbers of IC and $O C$ are the averages of thicknesses measured on typical surfaces. On most of the samples, isolated pitted areas had much greater oxide thickness. The maximum, local, pitting thickness measured on each set is also shown in Table 7. These are not typical but do show that some small spots of severe corrosion are common on enriched uranium surfaces, particularly if the storage time exceeds 1 month after machining. The photomicrographs in the next section illustrate this point. Note that not all pits were measured; some pits deeper than those listed could exist.

Table 7 shows that as storage time after machining increases, the oxide thickness increases. The oxide depth on the perc-cut parts increased linearly and essentially equally on both the IC and OC at a rate of $1.6 \mathrm{~nm} / \mathrm{d}$. The oxide growth on the boron-cut parts, however, decreased from its initial linear rate and was greater on the OC than on the IC. A plot of these results is shown in Fig. 26. The statistical analyses indicated that one linear regression line could be used to fit 
Table 7. Summary of IMMA determinations of oxide depth on the boron coolant-machined and perchloroethylene coolant-machined surfaces of enriched uranium

\begin{tabular}{|c|c|c|c|c|c|c|}
\hline \multirow[b]{2}{*}{ Part } & \multirow[b]{2}{*}{$\begin{array}{l}\text { Days after } \\
\text { machining }\end{array}$} & \multicolumn{5}{|c|}{ Depth (nm) } \\
\hline & & $\begin{array}{l}\text { Average } \\
\text { IC }\end{array}$ & $\begin{array}{l}\text { Average } \\
\text { OC }\end{array}$ & $\begin{array}{l}\text { Average } \\
\text { IC }+ \text { OC }\end{array}$ & $\begin{array}{c}\text { Grand } \\
\text { average }\end{array}$ & $\begin{array}{c}\text { Maximum } \\
\text { local } \\
\text { pitting }\end{array}$ \\
\hline & \multicolumn{6}{|c|}{ Boron coolant machined } \\
\hline $\begin{array}{l}5715 \\
5713\end{array}$ & $\begin{array}{l}30 \\
45\end{array}$ & $\begin{array}{l}68 \pm 37 \\
79 \pm 11\end{array}$ & $\begin{array}{r}59 \pm 22 \\
115 \pm 24\end{array}$ & $\begin{array}{l}64 \pm 28 \\
97 \pm 26\end{array}$ & $64 \pm 28$ & \\
\hline & 45 & & & & $101 \pm 22$ & 360 \\
\hline 5692 & 45 & $97 \pm 11$ & $119 \pm 23$ & $106 \pm 18$ & & \\
\hline \multirow[t]{2}{*}{5720} & $\begin{array}{l}75 \\
75\end{array}$ & $139 \pm 21$ & $162 \pm 74$ & $151 \mp 50$ & & \\
\hline & $\begin{array}{l}75 \\
75\end{array}$ & $159+28$ & $192+16$ & $176+27$ & $163 \pm 41$ & 1130 \\
\hline 5727 & 225 & $329 \mp 71$ & $217 \pm 104$ & $273 \mp 100$ & $273 \pm 100$ & $\sim 2000$ \\
\hline \multicolumn{7}{|c|}{ Perc coolant machined } \\
\hline 5725 & $\begin{array}{l}45 \\
45\end{array}$ & $113 \pm 20$ & $124 \pm 13$ & $119 \pm 16$ & $114+18$ & 1400 \\
\hline $\begin{array}{l}5726 \\
5730\end{array}$ & $\begin{array}{l}45 \\
75\end{array}$ & $\begin{array}{r}97 \pm 23 \\
178 \div 16\end{array}$ & $\begin{array}{l}122 \pm 6 \\
190 \pm 33\end{array}$ & $\begin{array}{l}111 \pm 20 \\
184+24\end{array}$ & & \\
\hline 400 & 75 & $170 \pm 10$ & $170 \pm 20$ & $104 \geq 24$ & $168 \pm 31$ & 1040 \\
\hline $\begin{array}{l}5733 \\
5739\end{array}$ & $\begin{array}{r}75 \\
225\end{array}$ & $\begin{array}{l}159 \pm 46 \\
416 \pm 30\end{array}$ & $\begin{array}{l}139 \pm 19 \\
394 \mp 44\end{array}$ & $\begin{array}{l}152 \pm 30 \\
406 \div 38\end{array}$ & & \\
\hline & 225 & & & & $414 \pm 41$ & $\sim 2000$ \\
\hline 5740 & 225 & $447 \pm 44$ & $392 \pm 17$ & $423+44$ & & \\
\hline
\end{tabular}

all the data from the perc coolant-machined parts and that a second linear regression line could be used to fit all the data from the boron coolant-machined parts. This results in a slope or linear oxide growth rate of $1.0 \mathrm{~nm} / \mathrm{d}$ for the boron-cut parts and $1.6 \mathrm{~nm} / \mathrm{d}$ for the perc-cut parts. If these rates remain unchecked, spalling of oxide from the surface could be expected in $~ 1000 \mathrm{~d}$ after machining for the boron-cut parts and $\sim 600 \mathrm{~d}$ for the perc-cut parts when the oxide reaches $1 \mathrm{\mu m}$ in thickness.

This study of oxide growth on enriched uranium parts in a normal environment showed that boron coolant-machined surfaces oxidized at significantly lower rates than the perc coolant-machined surfaces. 


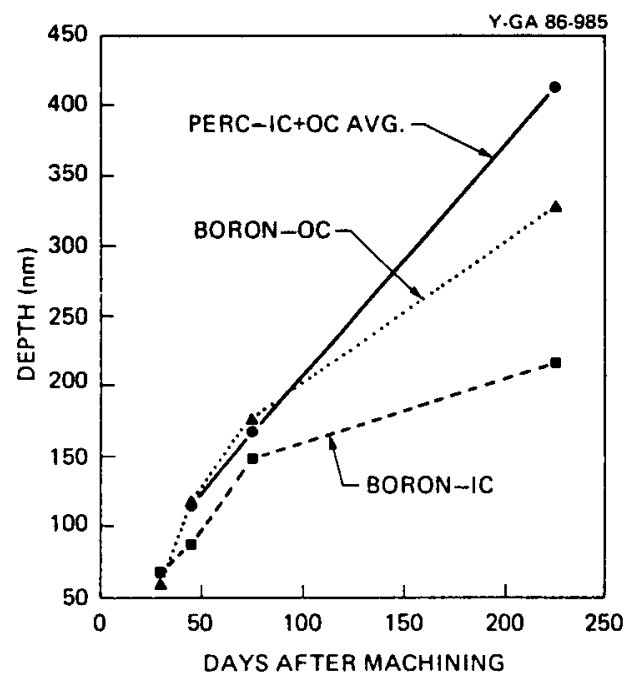

Fig. 26. Oxide growth on perc- and boron-cut parts.

\section{SURFACE MORPHOLOGY AND LOCAL CORROSION}

The scanning electron microscope (SEM) was utilized to survey both the IC and OC of all coupons. The same samples used in the IMMA analyses were used for the SEM work. The coupons were rinsed in Freon 113 just prior to the SEM analysis. A series of photomicrographs ranging in magnification from $100 X$ to $3000 X$ were made from a representative area of each coupon.

Corrosion pits were found on all surfaces examined, with the smallest number observed on the specimens like those sent to Rocky Flats (exposed to $\mathrm{Y}-12$ environment for $30 \mathrm{~d}$ after final machining). The lengths of the pits ranged from less than $2 \mu \mathrm{m}$ to greater than $20 \mu \mathrm{m}$. The pits were randomly dispersed, both individually and in groups. Except for the Rocky Flats-type coupons, all coupons regardless of their location or coolant used showed approximately the same degree of pitting. Also randomly dispersed were areas where the oxide growth pattern could be observed.

The various types of pitting and oxide growth patterns can be seen in Figs. 27 through 40 . The highest magnification (3000X) photomicrograph in each figure shows either the detail of the pitting or the oxide growth. The relative sizes of the pits can be compared in the $1000 \mathrm{X}$ views, while the $300 \mathrm{X}$ photomicrographs, show the distribution of the pits in the same area. Figures 41 and 42 compare (at 1000X) the surface morphologies $v s$ time after final machining for the boron-cut parts and the perc-cut parts, respectively. 


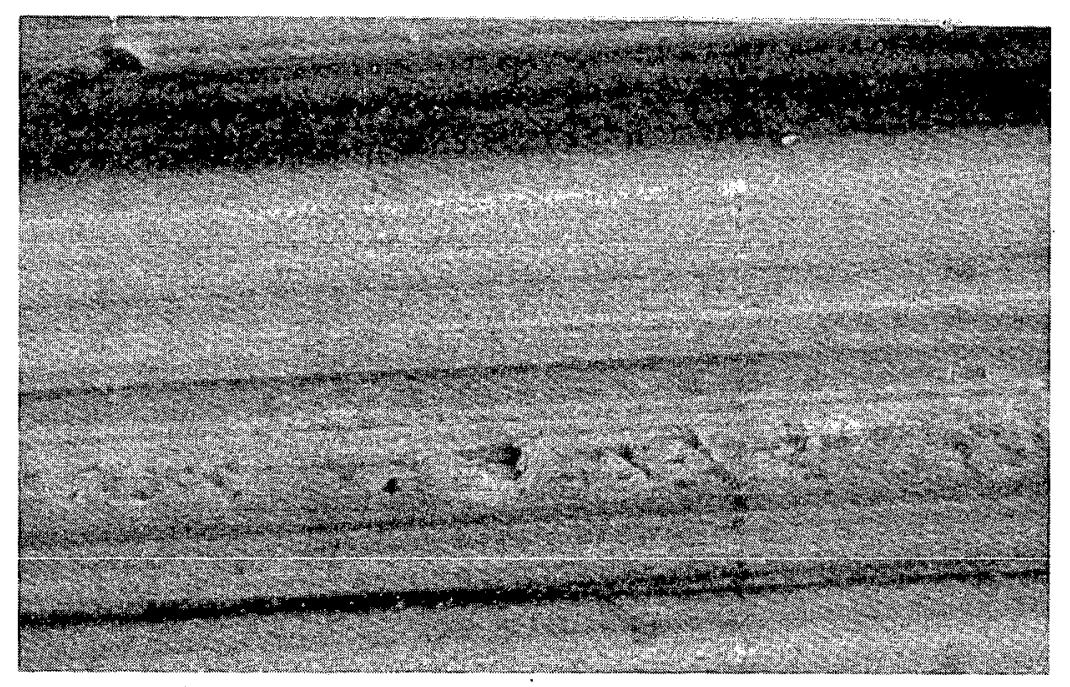

(a)

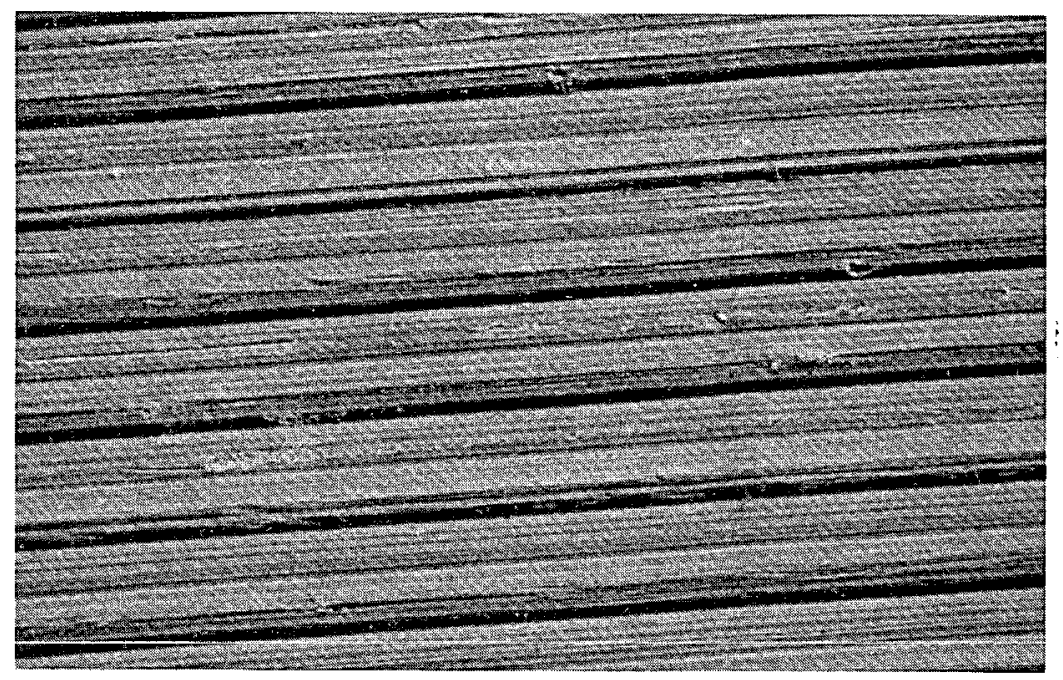

(c)

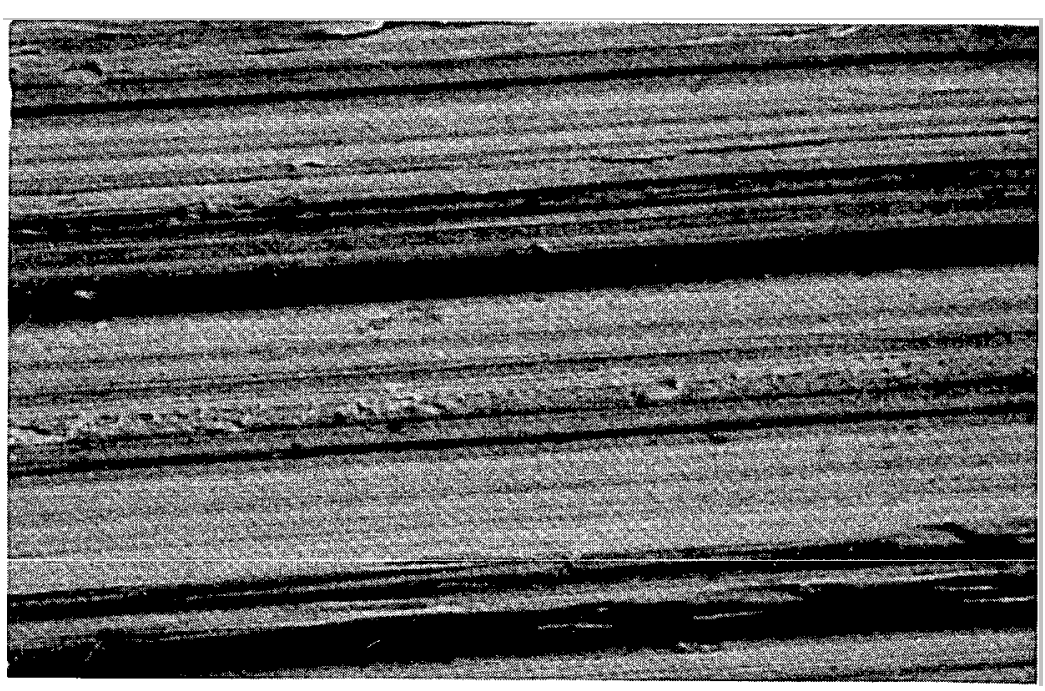

(b)

Fig. 27. Pitting and oxide growth patterns of boron coolant-machined part 5715 shown 30 d after final machining on the IC at $45^{\circ}$. Magnification: (a) $3000 \mathrm{X}$, (b) $1000 \mathrm{X}$, (c) $300 \mathrm{X}$. 


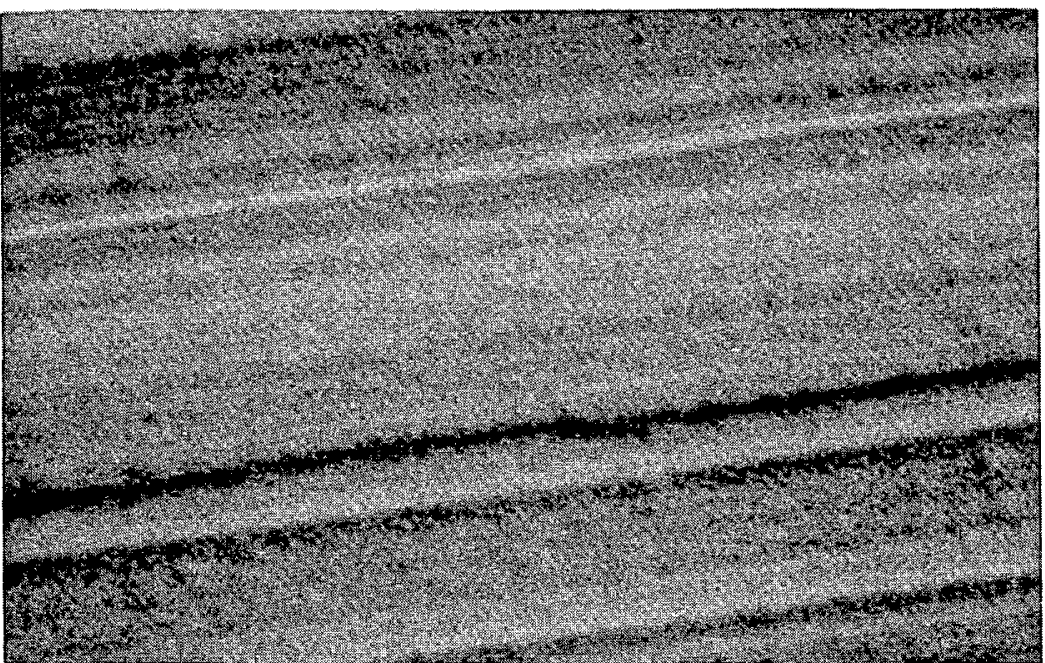

(a)

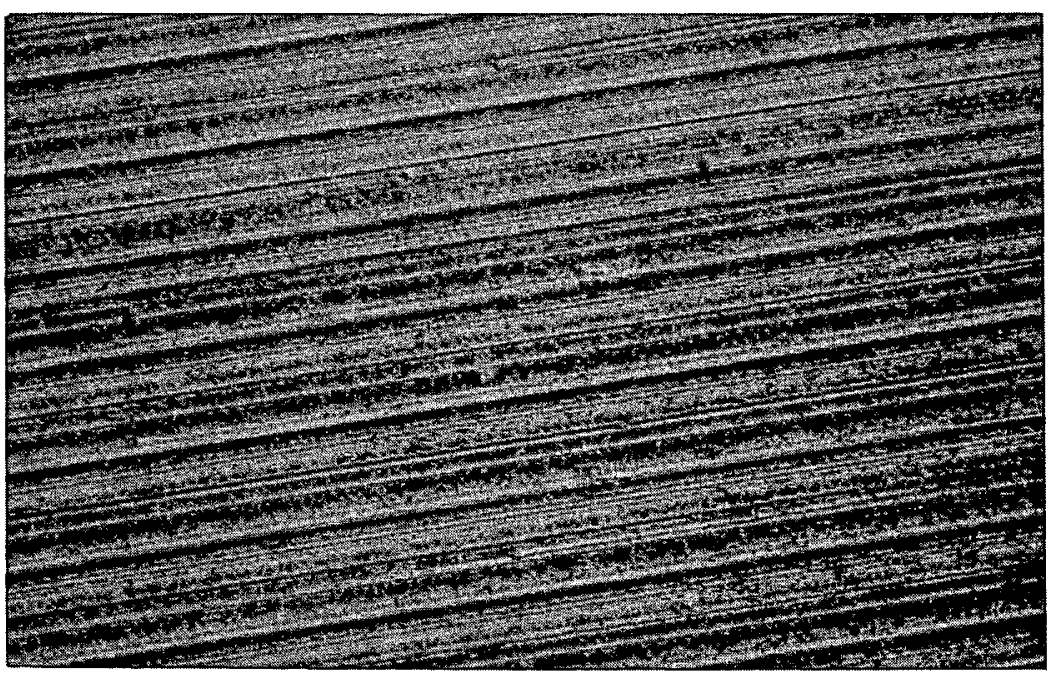

(c)

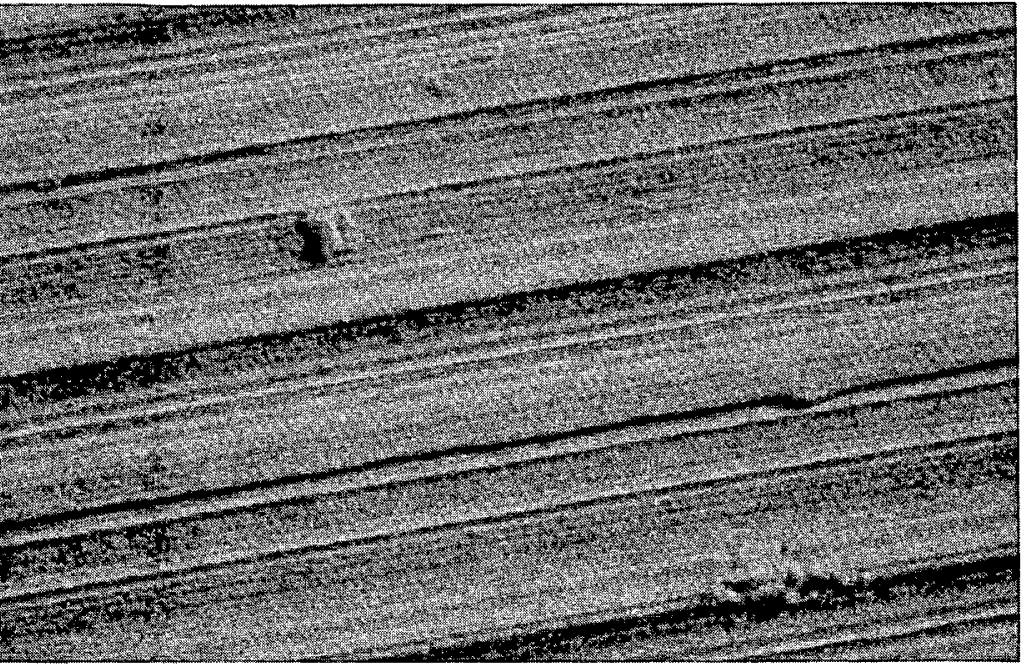

(b)

Fig. 28. Pitting and oxide growth patterns of boron coolant-machined part 5715 shown $30 \mathrm{~d}$ after final machining on the $O C$ at the pole. Magnification: (a) $3000 \mathrm{X}$, (b) $1000 \mathrm{X}$, (c) $300 \mathrm{X}$. 


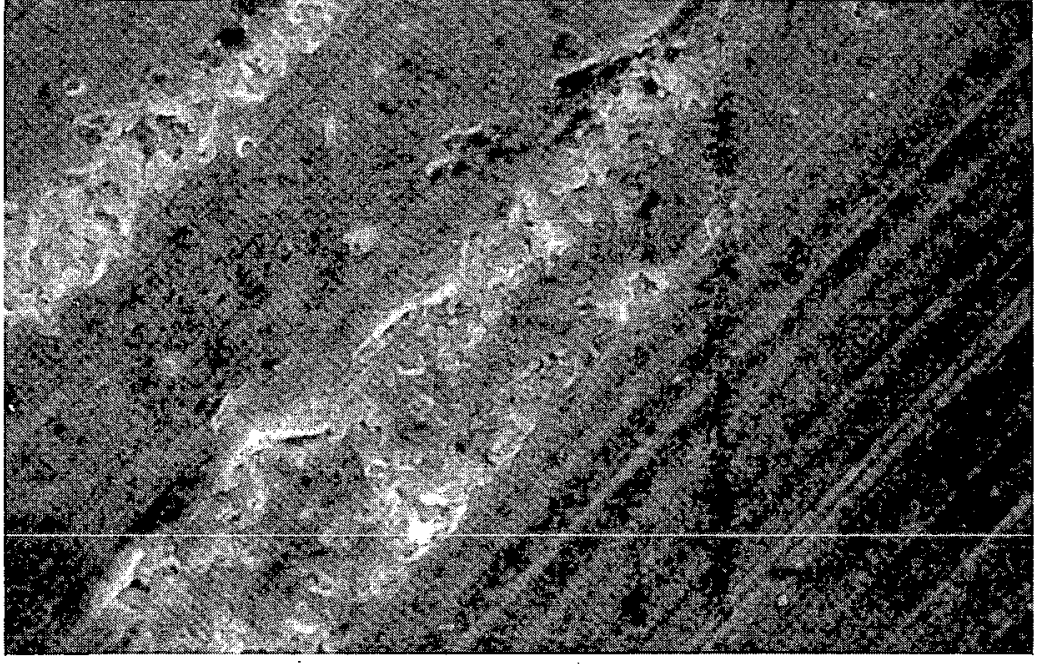

(a)

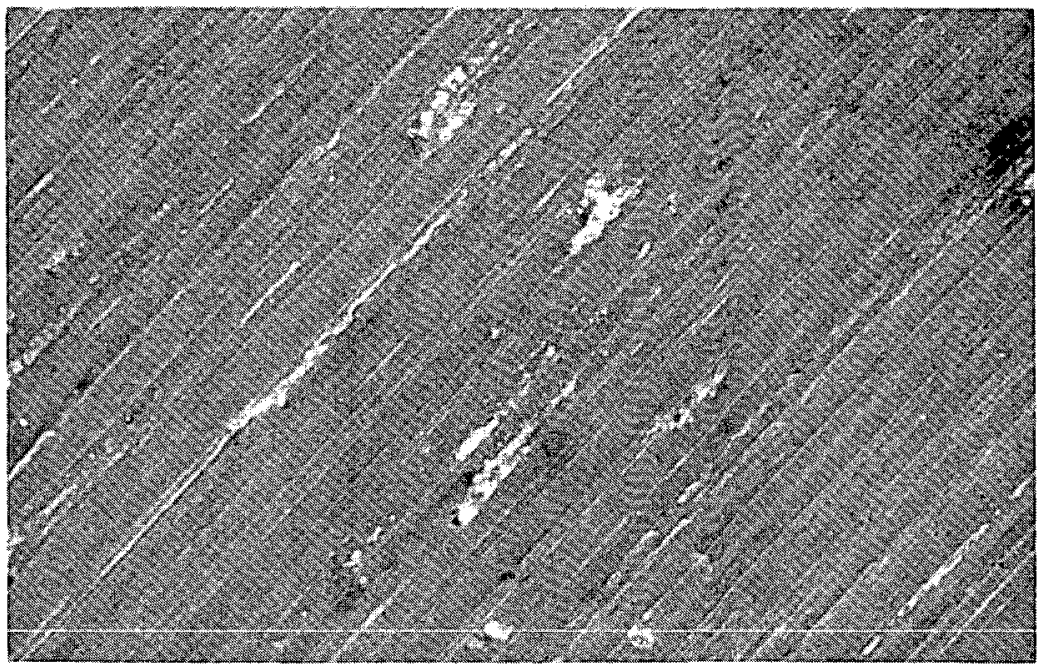

(c)

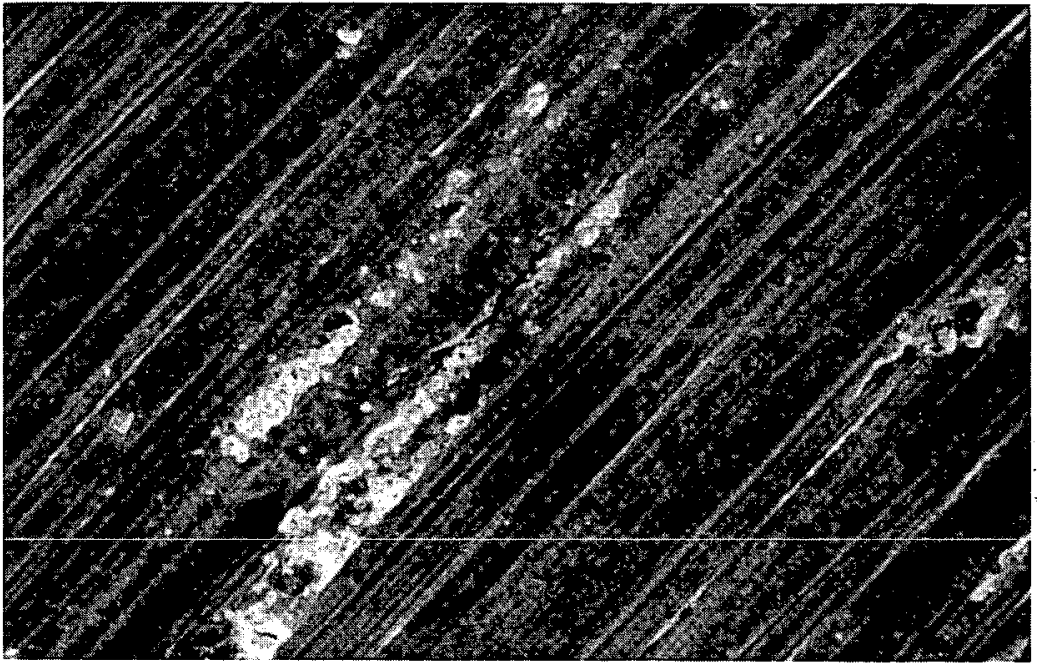

(b)

Fig. 29. Pitting and oxide growth patterns of boron coolant-machined part 5692 shown 45 d after final machining on the IC at $45^{\circ}$. Magnification: (a) $3000 \mathrm{X}$, (b) $1000 \mathrm{X}$, (c) $300 \mathrm{X}$. 


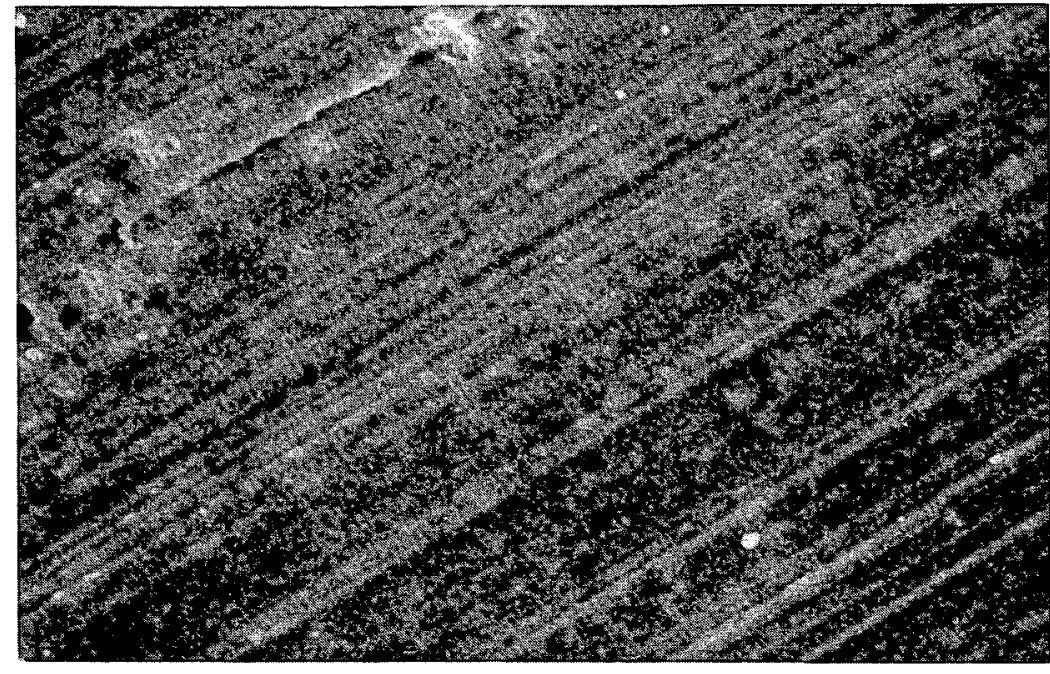

(a)

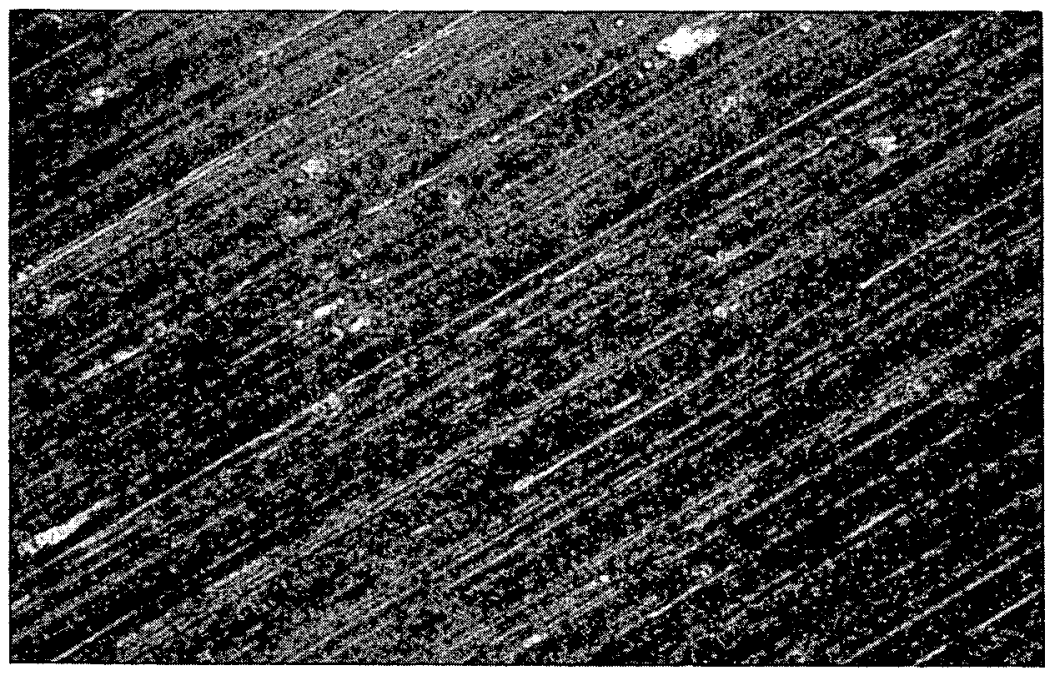

(c)

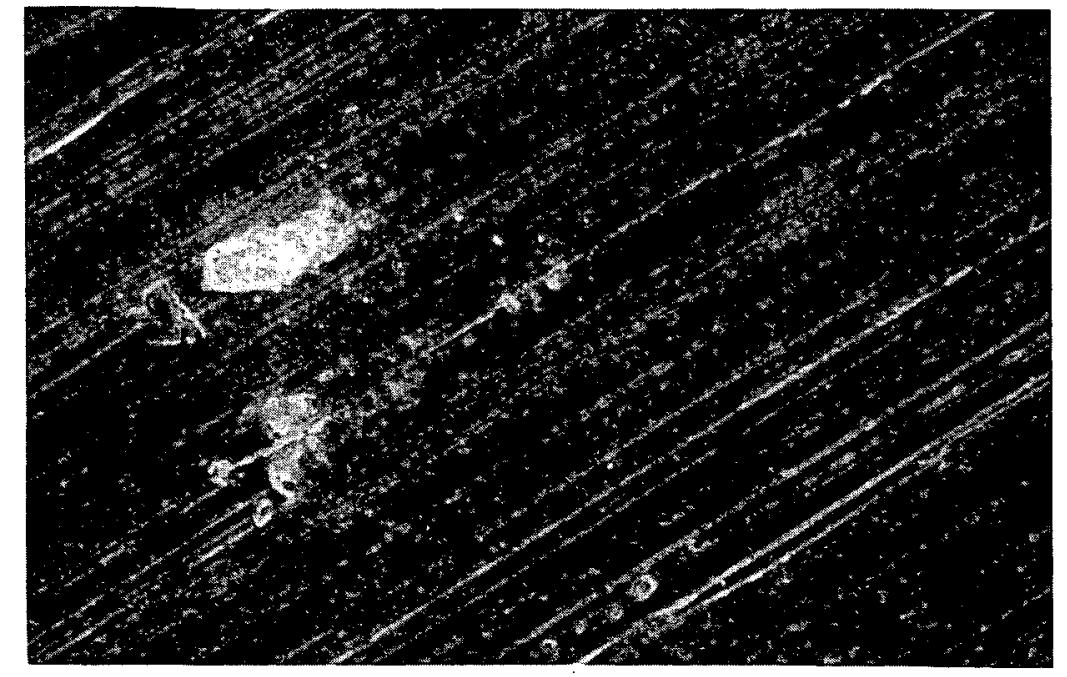

(b)

Fig. 30. Pitting and oxide growth patterns of boron coolant-machined part 5713 shown 45 d after final machining on the $O C$ at the mouth. Magnification: (a) $3000 \mathrm{X}$, (b) $1000 \mathrm{X}$, (c) $300 \mathrm{X}$. 


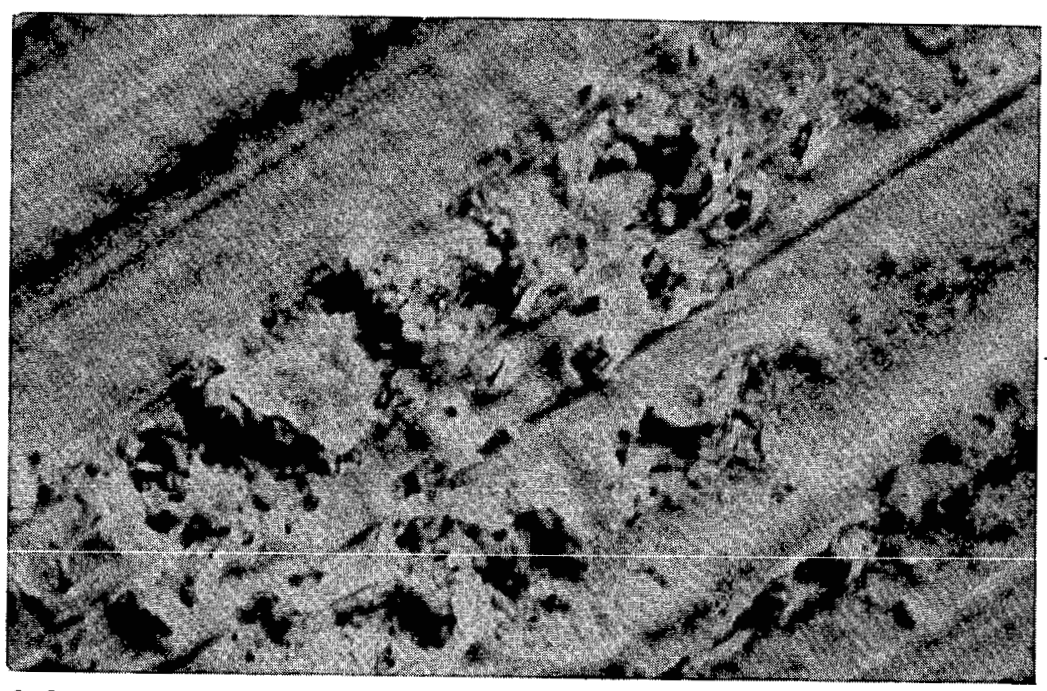

(a)

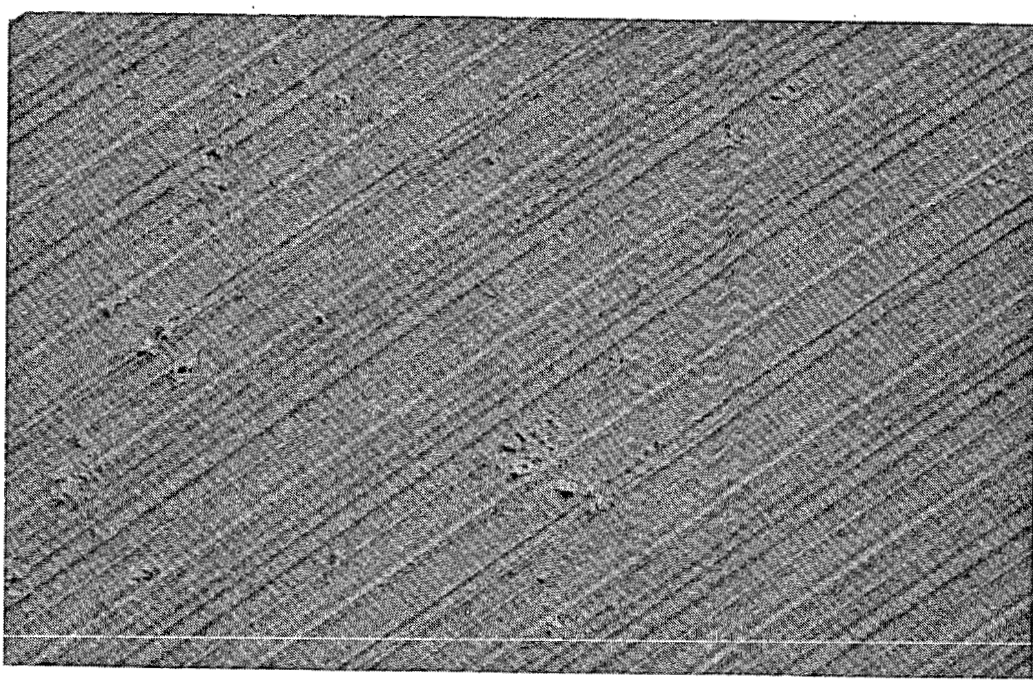

(c)

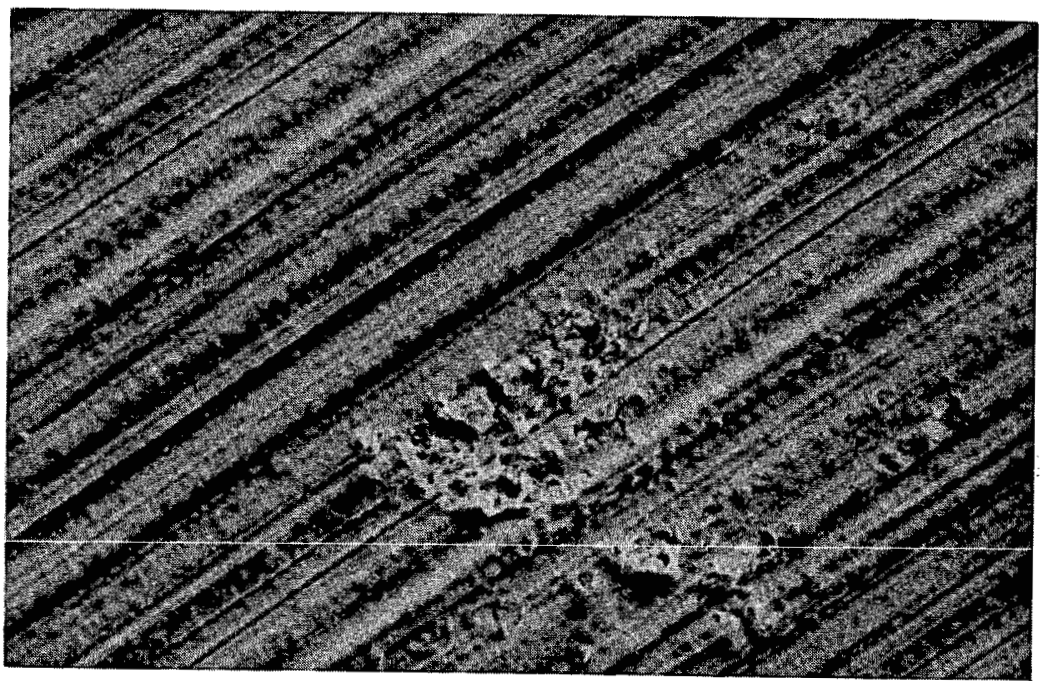

(b)

Fig. 31. Pitting and oxide growth patterns of boron coolant-machined part 5720 shown 75 d after final machining on the IC at the mouth. Magnification: (a) $3000 \mathrm{X}$, (b) $1000 \mathrm{X}$, (c) $300 \mathrm{X}$. 


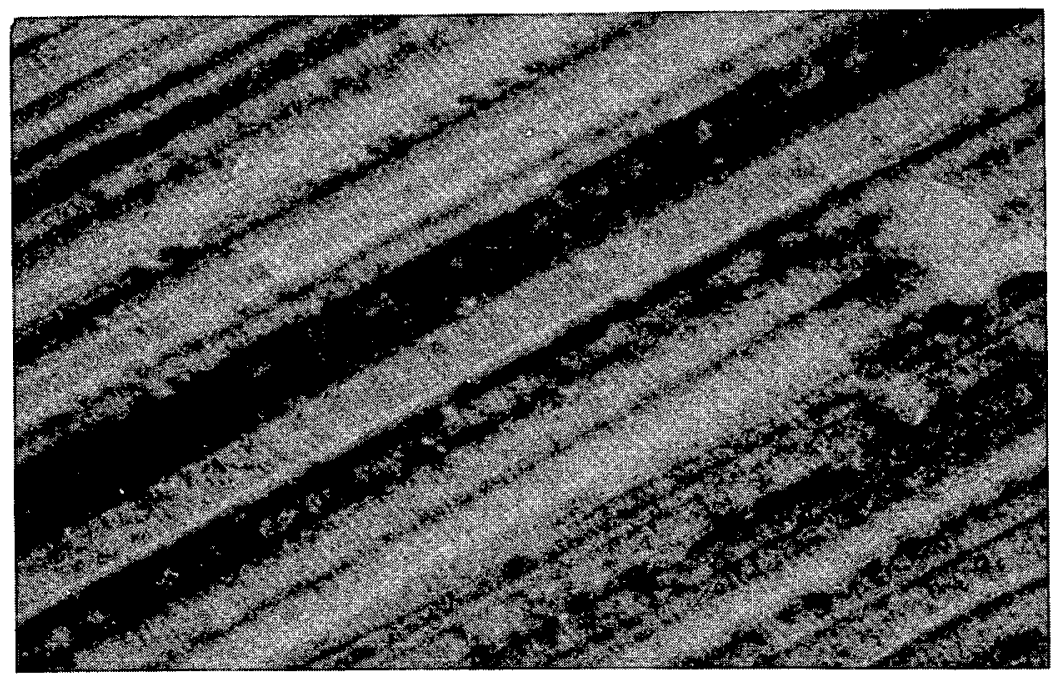

(a)

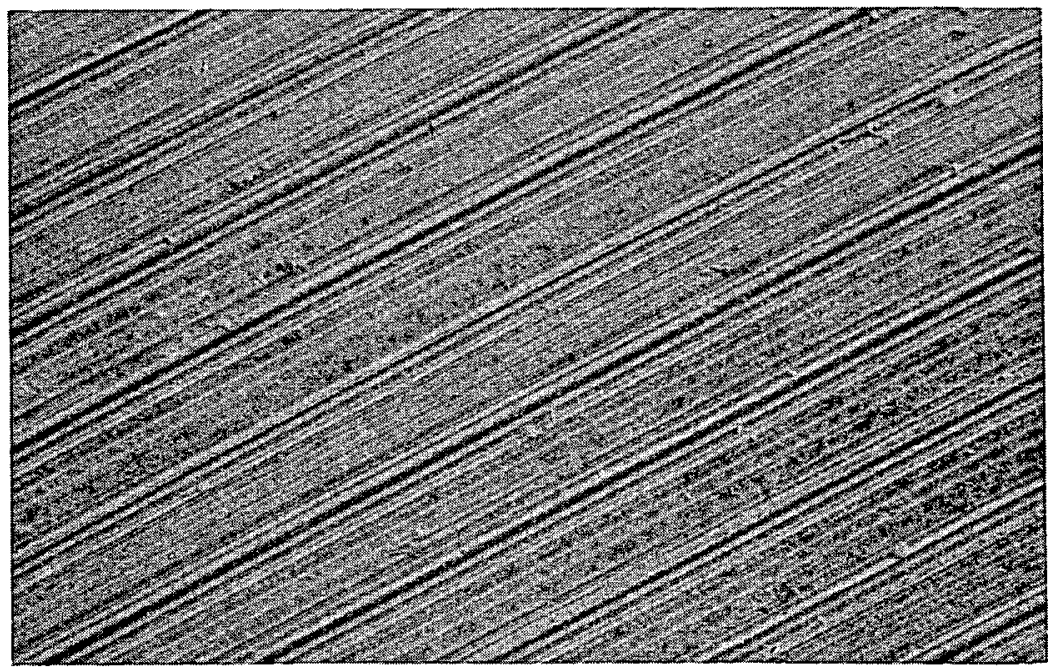

(c)

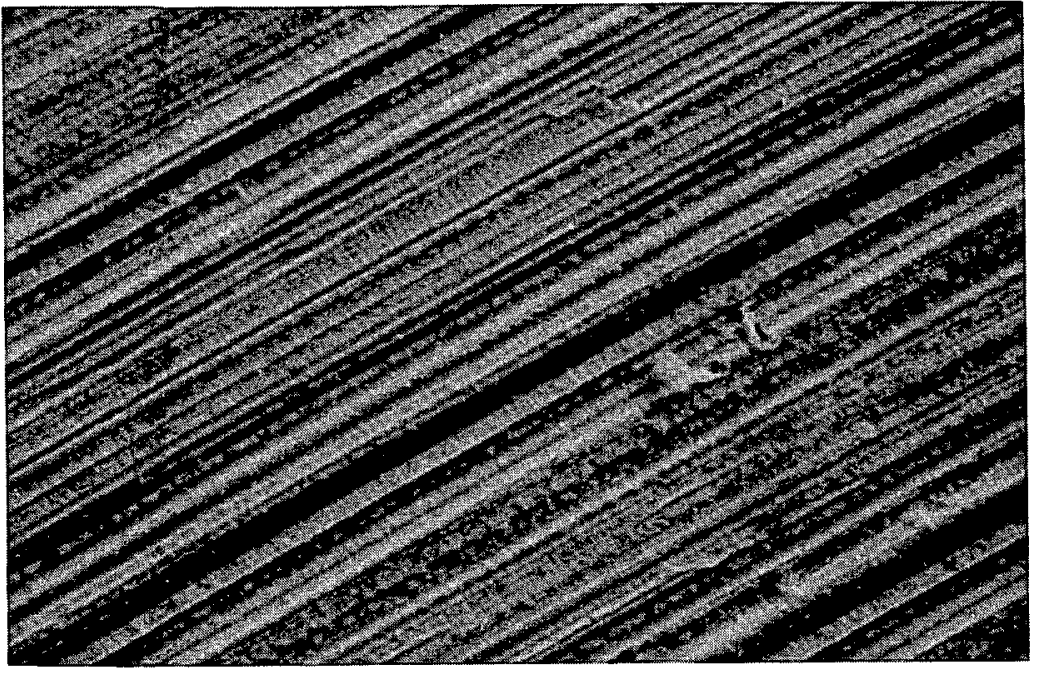

(b)

Fig. 32. Pitting and oxide growth patterns of boron coolant-machined part 5722 shown 75 d after final machining on the $O C$ at the pole. Magnification: (a) $3000 \mathrm{X}$, (b) $1000 \mathrm{X}$, (c) $300 \mathrm{X}$. 


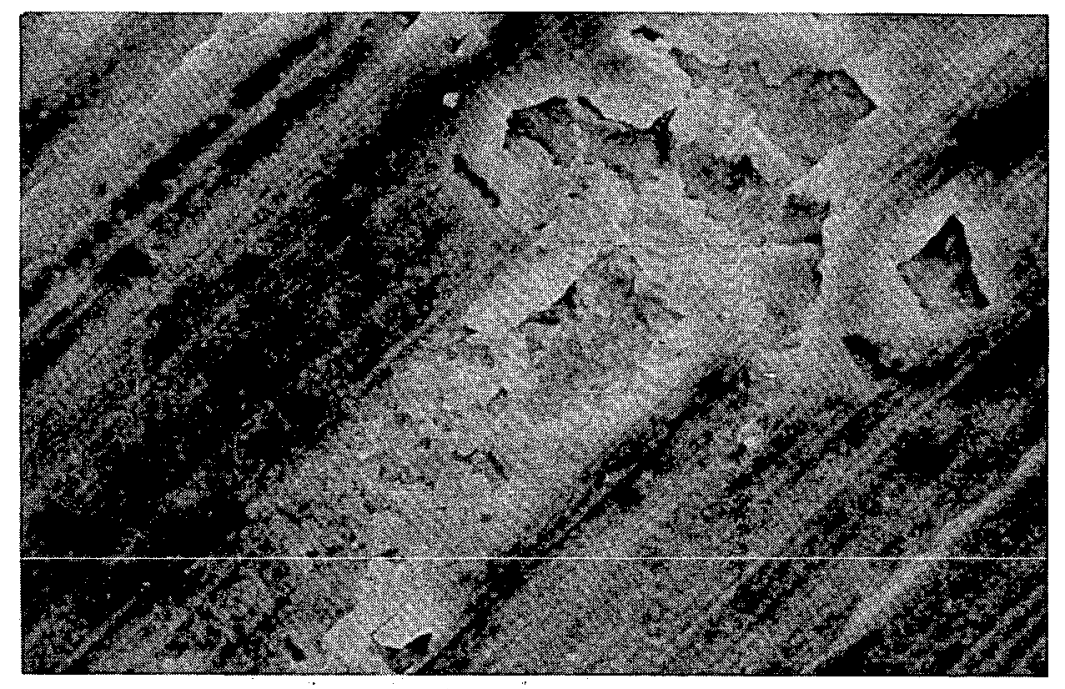

(a)

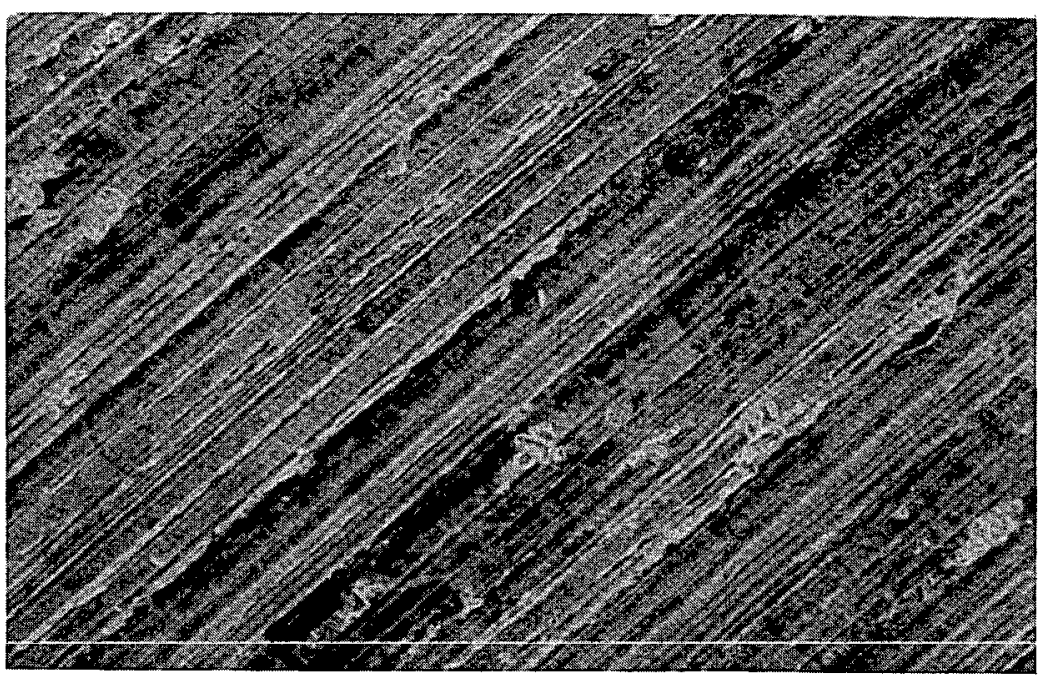

(c)

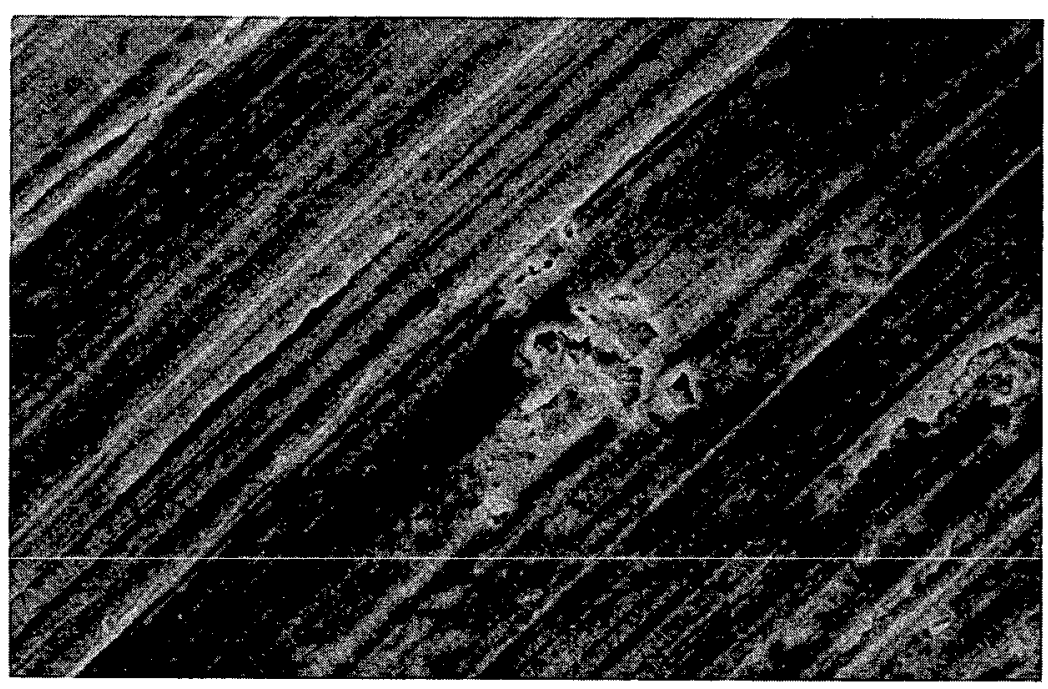

(b)

Fig. 33. Pitting and oxide growth patterns of boron coolant-machined part 5727 shown 225 d after final machining on the IC at $45^{\circ}$. Magnification: (a) $3000 \mathrm{X}$, (b) $1000 \mathrm{X}$, (c) $300 \mathrm{X}$. 


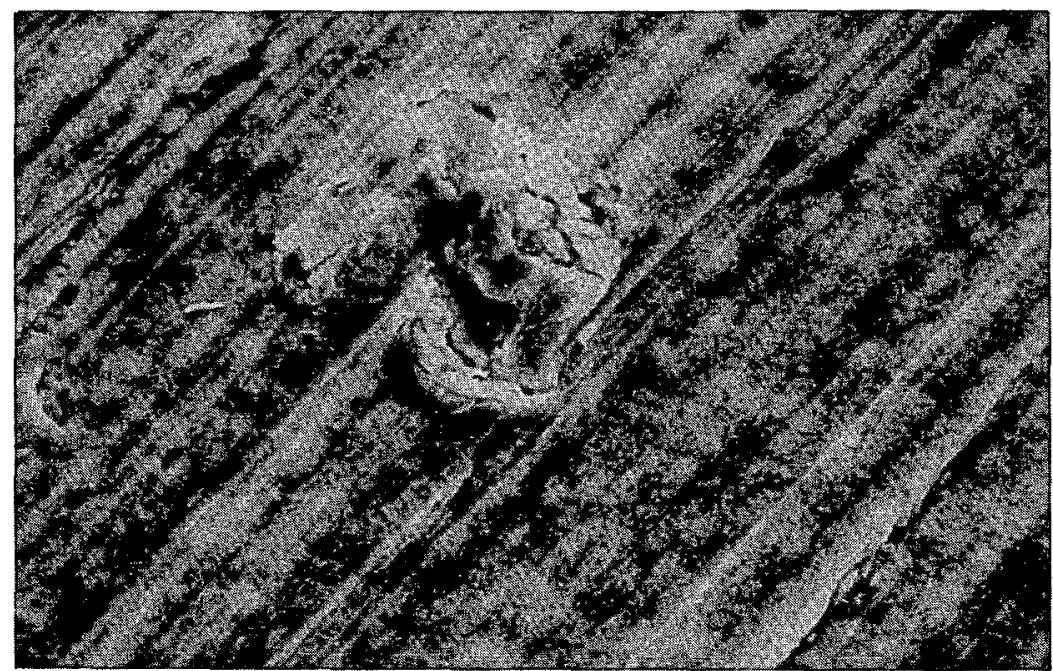

(a)

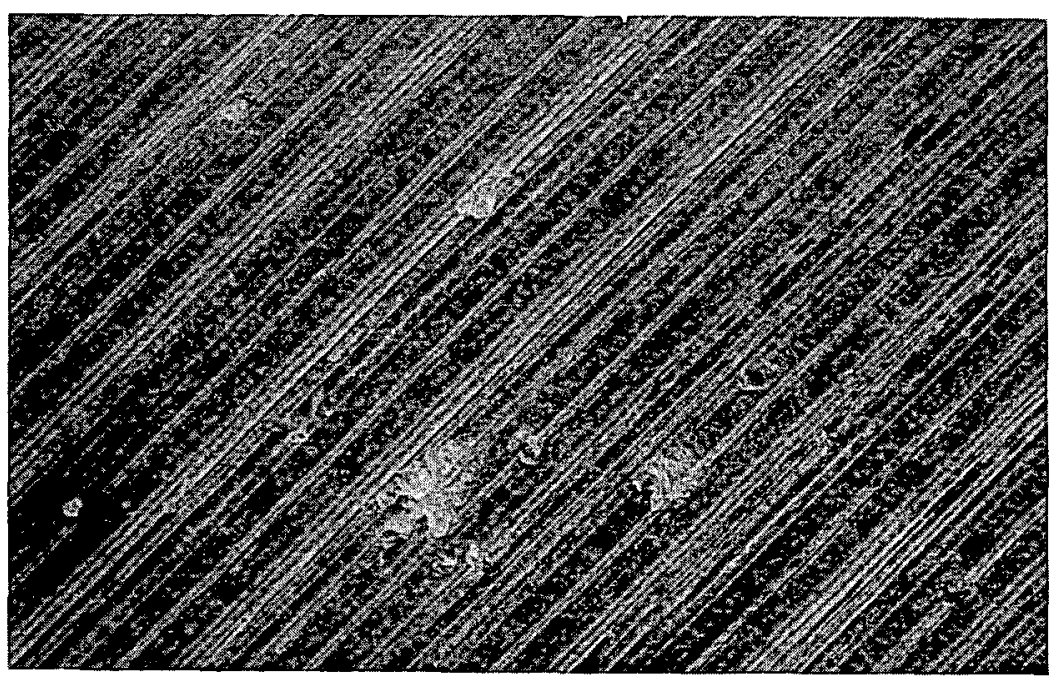

(c)

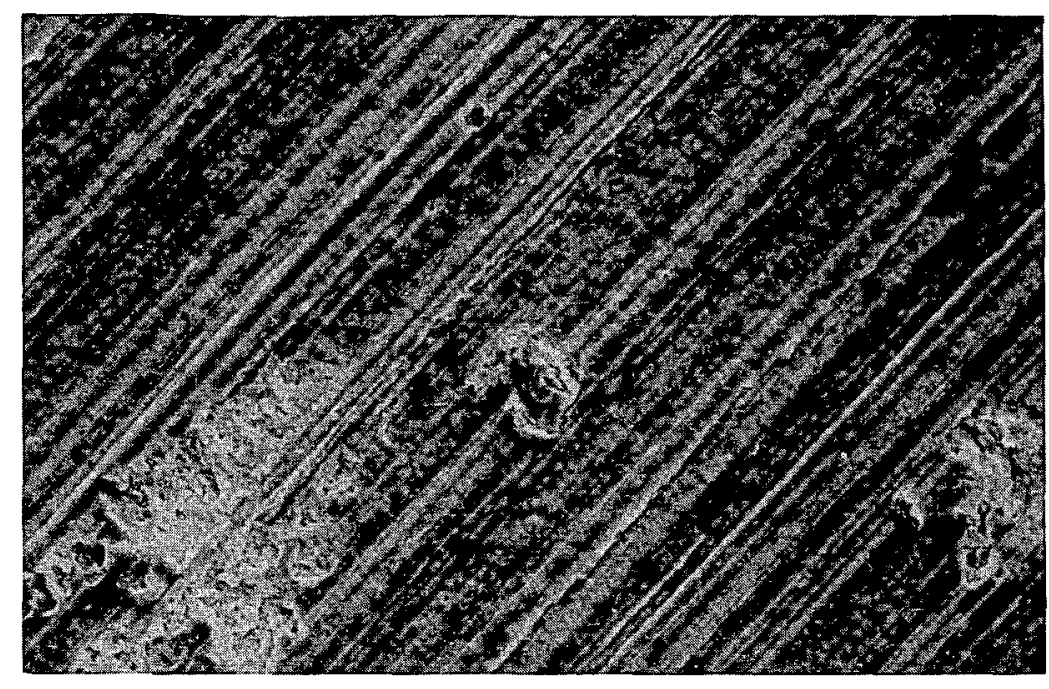

(b)

Fig. 34. Pitting and oxide growth patterns of boron coolant-machined part 5727 shown 225 d after final machining on the $O C$ at $45^{\circ}$. Magnification: (a) $3000 \mathrm{X}$, (b) $1000 \mathrm{X}$, (c) $300 \mathrm{X}$. 


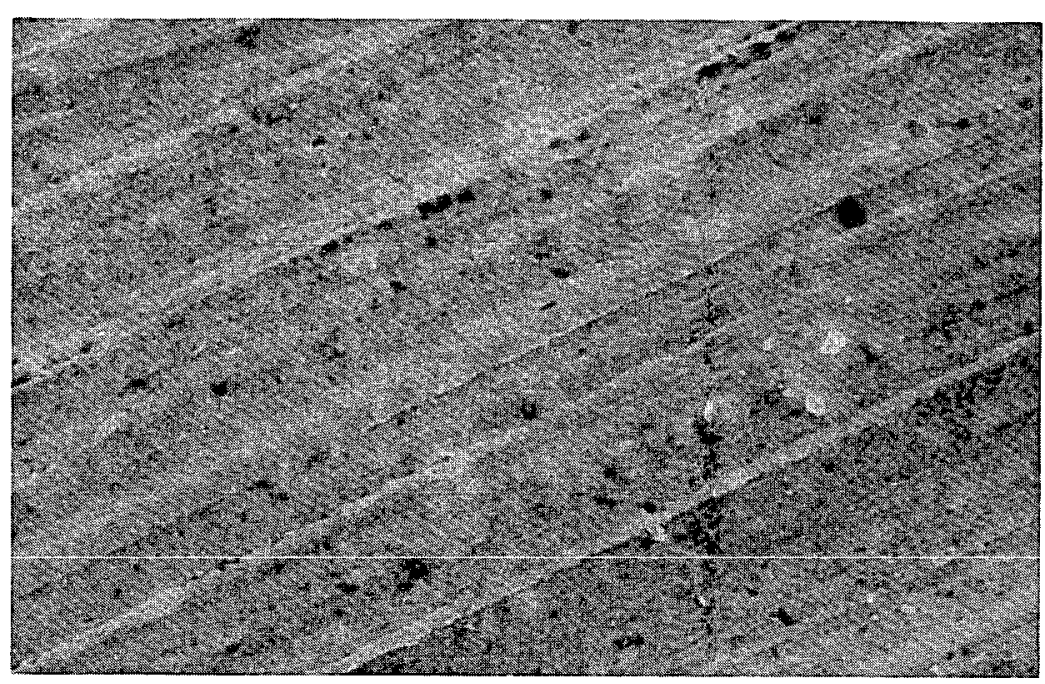

(a)

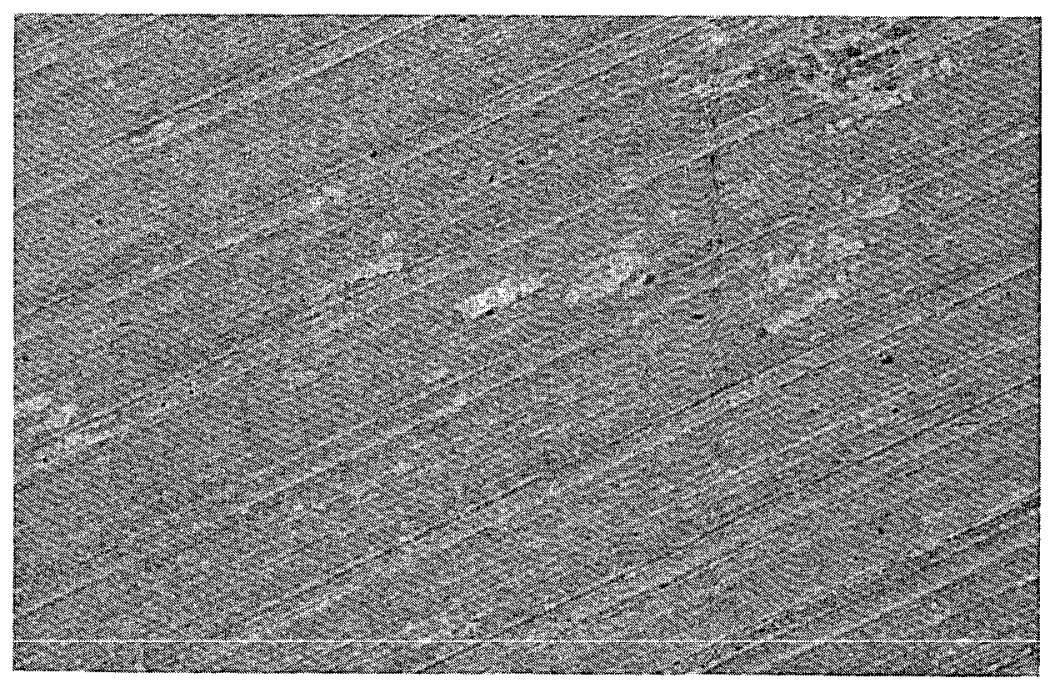

(c)

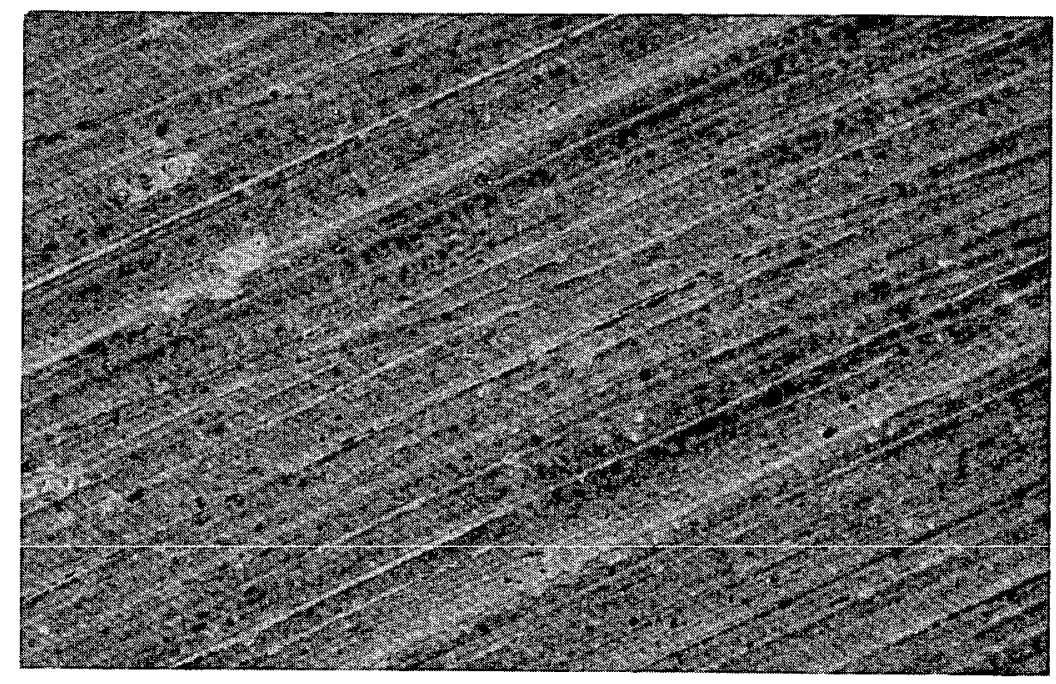

(b)

Fig. 35. Pitting and oxide growth patterns of perc coolant-machined part 5725 shown 45 d after final machining on the $I C$ at the mouth. Magnification: (a) $3000 \mathrm{X}$, (b) $1000 \mathrm{X}$, (c) $300 \mathrm{X}$. 


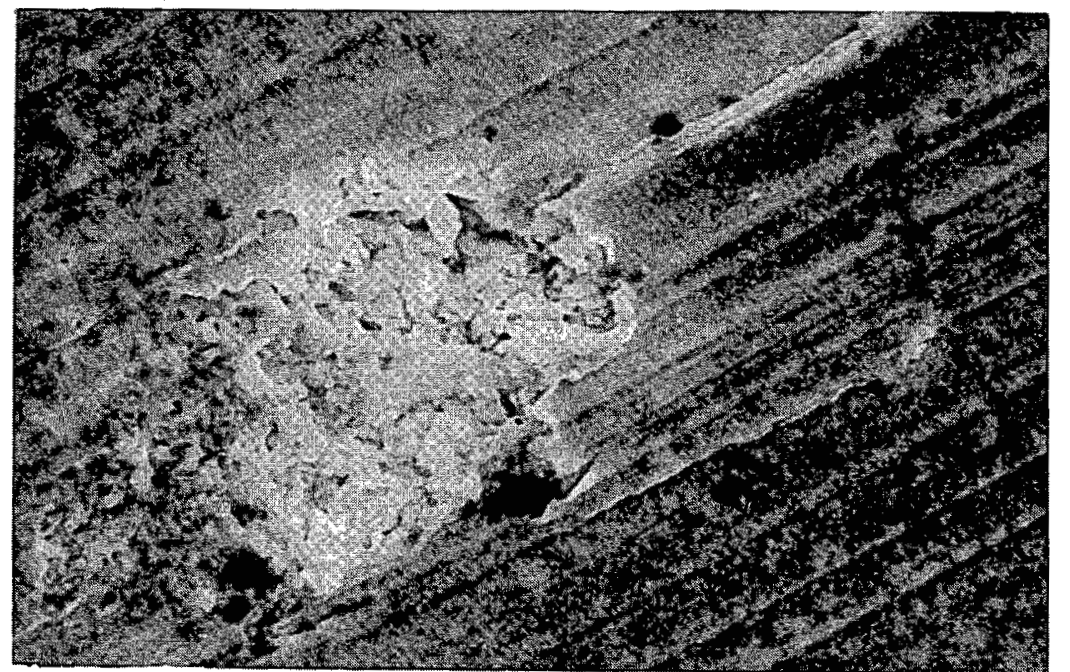

(a)

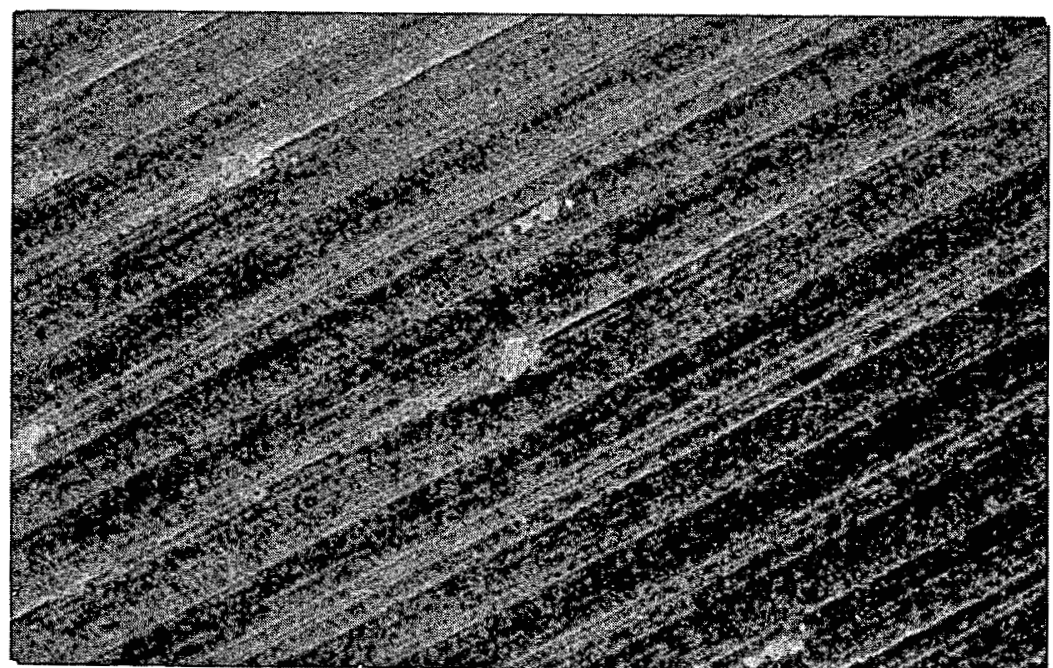

(c)

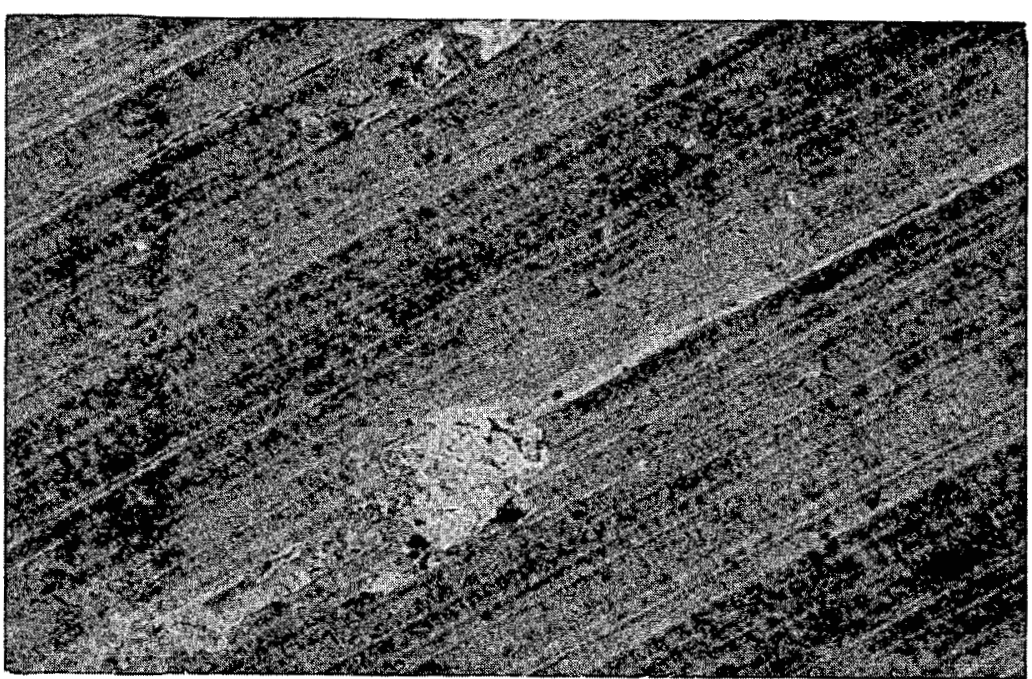

(b)

Fig. 36. Pitting and oxide growth patterns of perc coolant-machined part 5726 shown 45 d after final machining on the IC at the mouth. Magnification: (a) $3000 \mathrm{X}$, (b) $1000 \mathrm{X}$, (c) $300 \mathrm{X}$. 


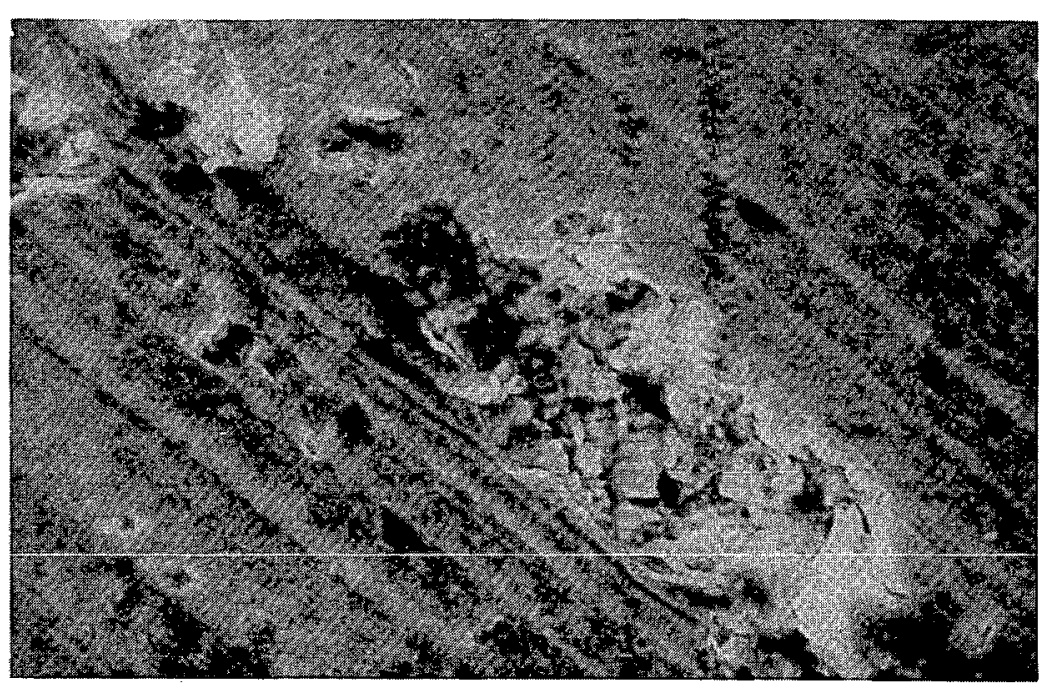

(a)

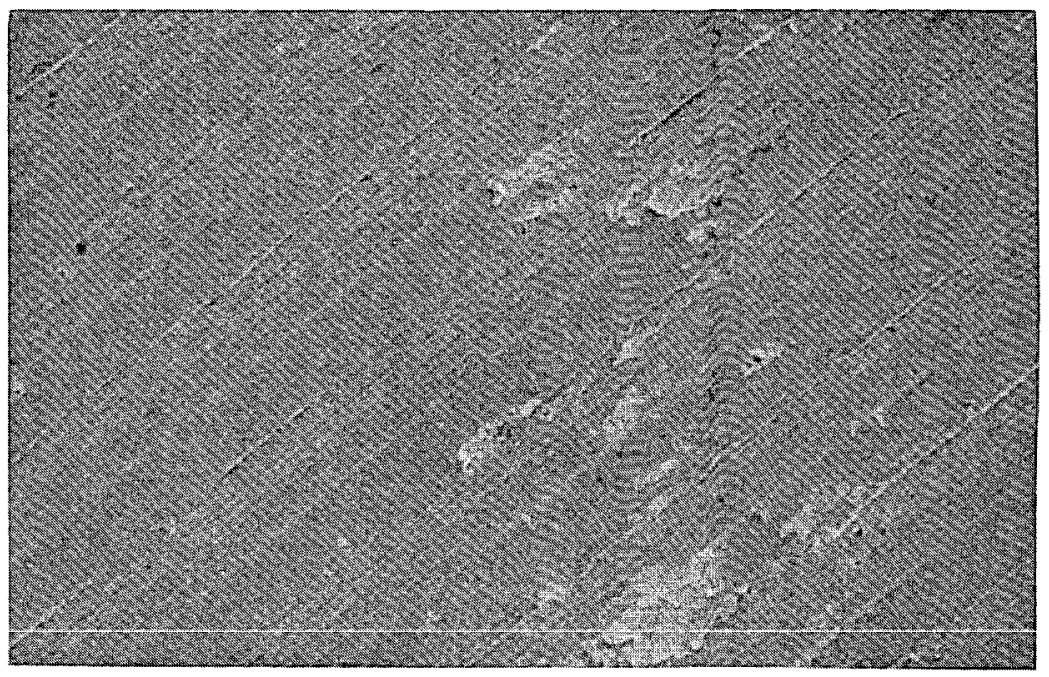

(c)

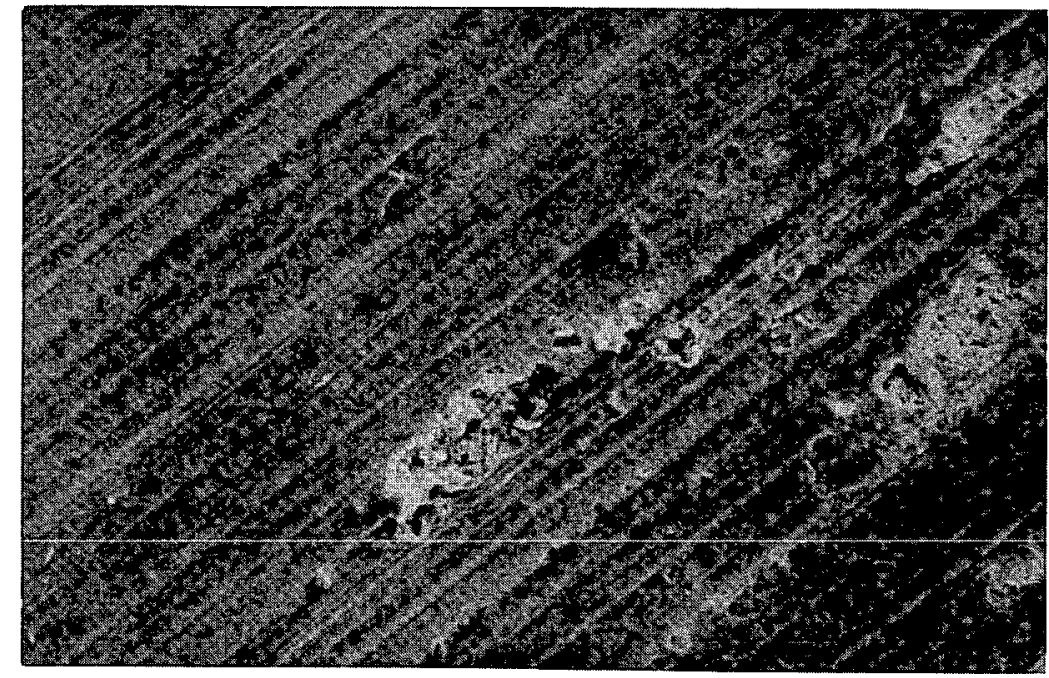

(b)

Fig. 37. Pitting and oxide growth patterns of perc coolant-machined part 5730 shown 75 d after final machining on the IC at the pole. Magnification: (a) $3000 \mathrm{X}$, (b) $1000 \mathrm{X}$, (c) $300 \mathrm{X}$. 


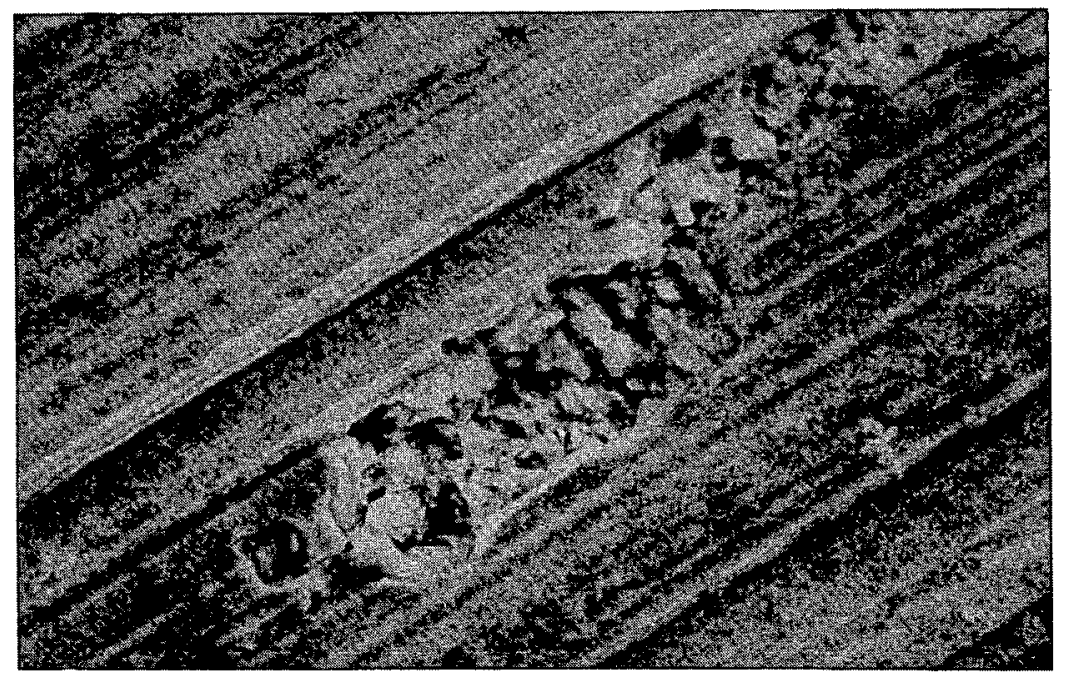

(a)

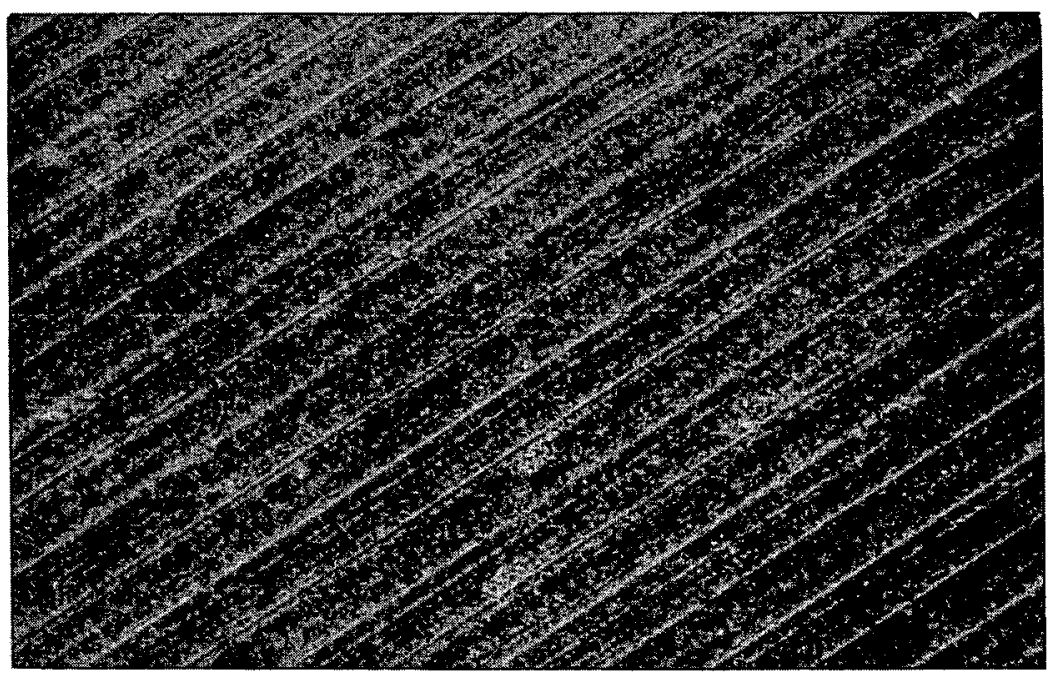

(c)

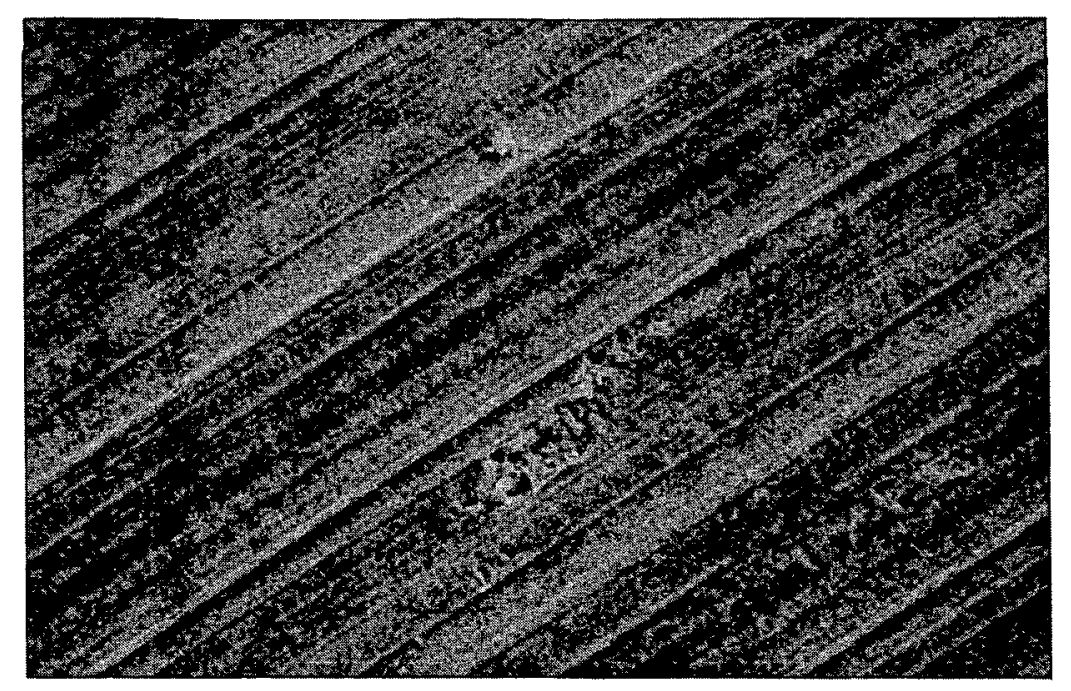

(b)

Fig. 38. Pitting and oxide growth patterns of perc coolant-machined part 5733 shown 75 d after final machining on the $O C$ at the pole. Magnification: (a) $3000 \mathrm{X}$, (b) $1000 \mathrm{X}$, (c) $300 \mathrm{X}$. 


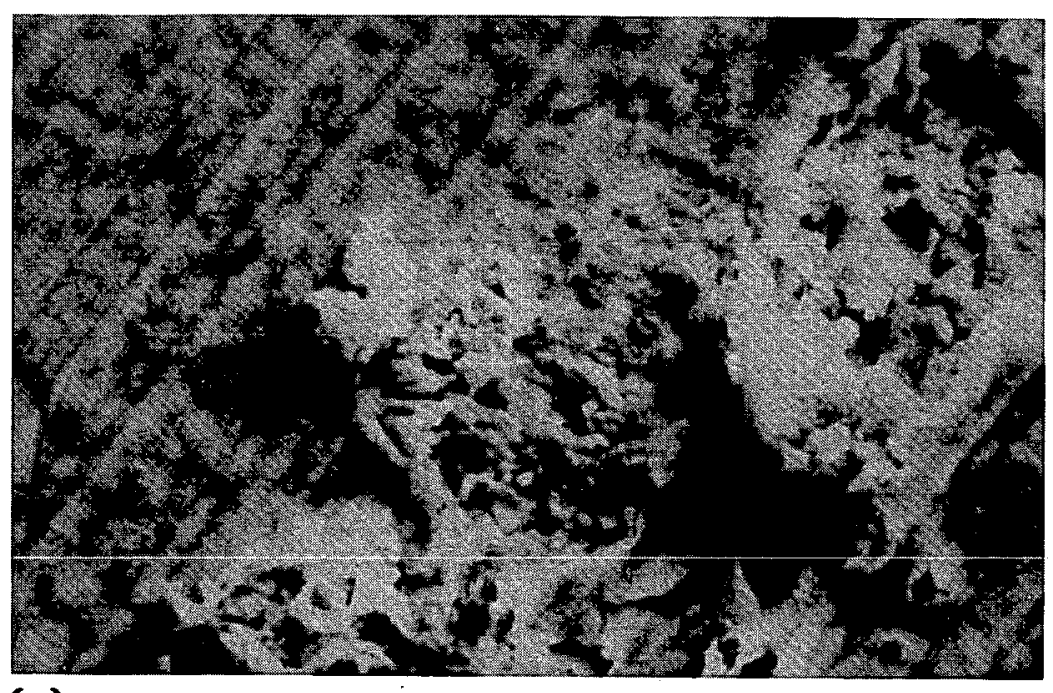

(a)

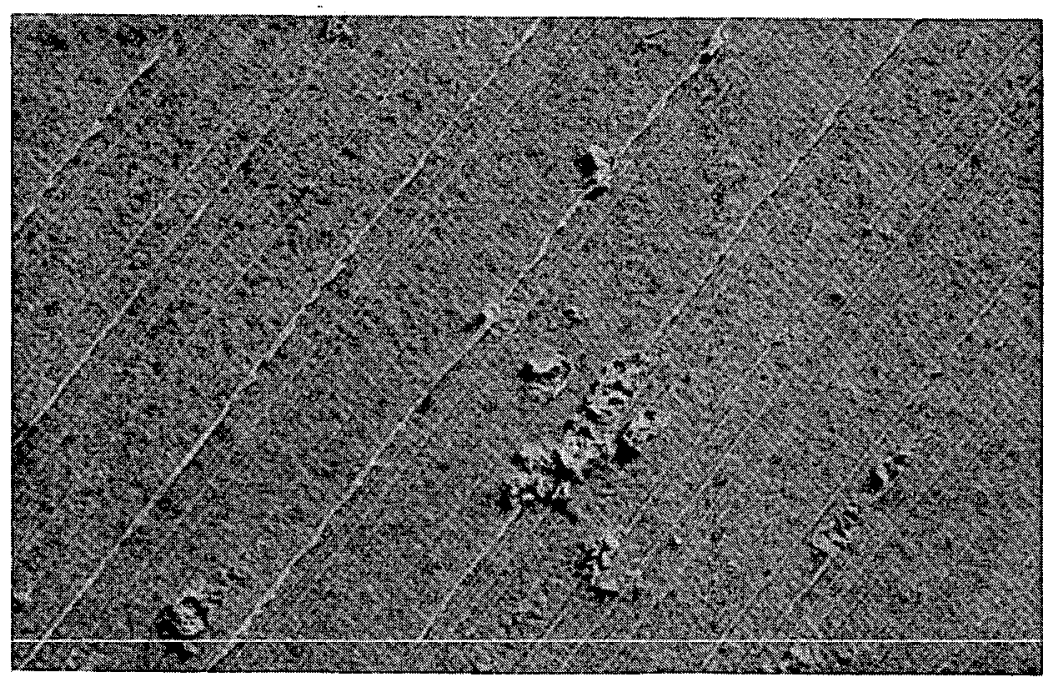

(c)

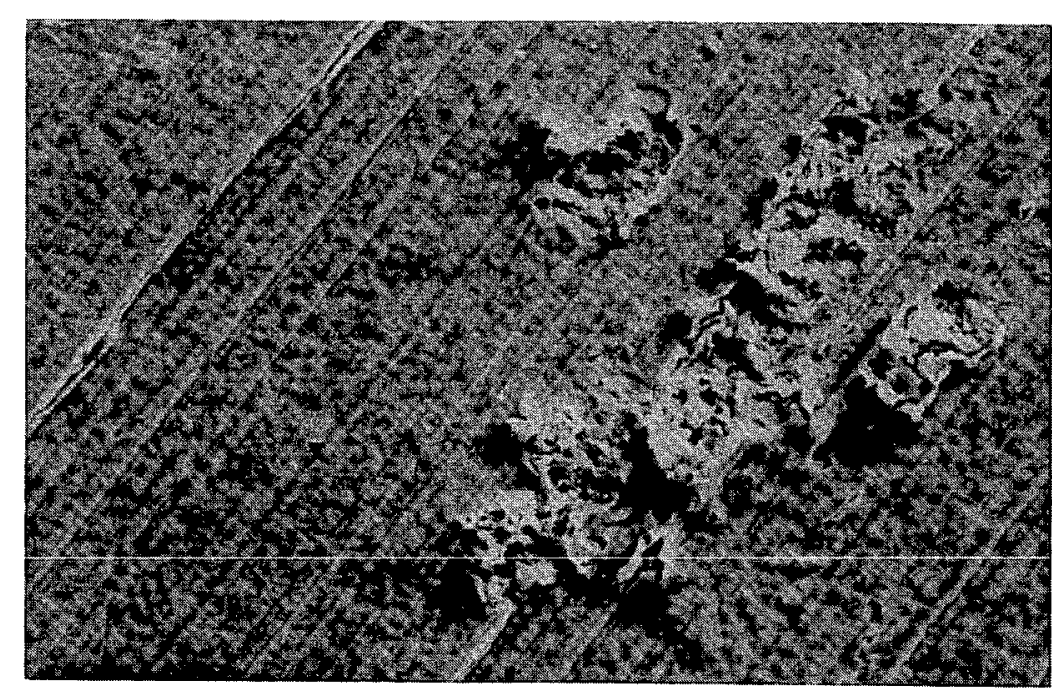

(b)

Fig. 39. Pitting and oxide growth patterns of perc coolant-machined part 5739 shown 225 d after final machining on the IC at $45^{\circ}$. Magnification: (a) $3000 \mathrm{X}$, (b) $1000 \mathrm{X}$, (c) $300 \mathrm{X}$. 


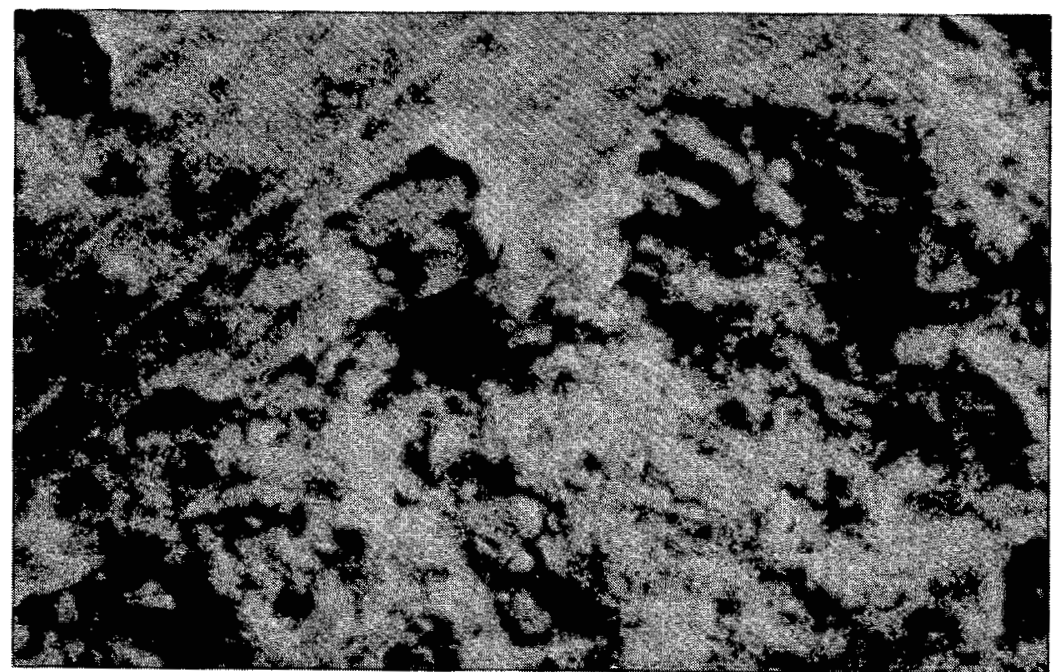

(a)

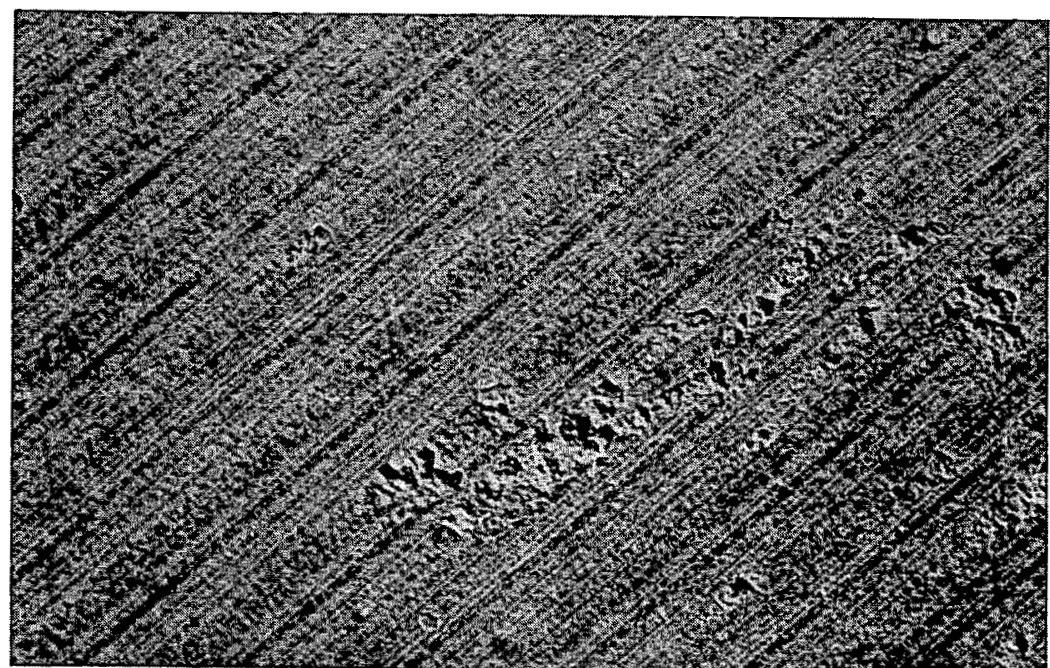

(c)

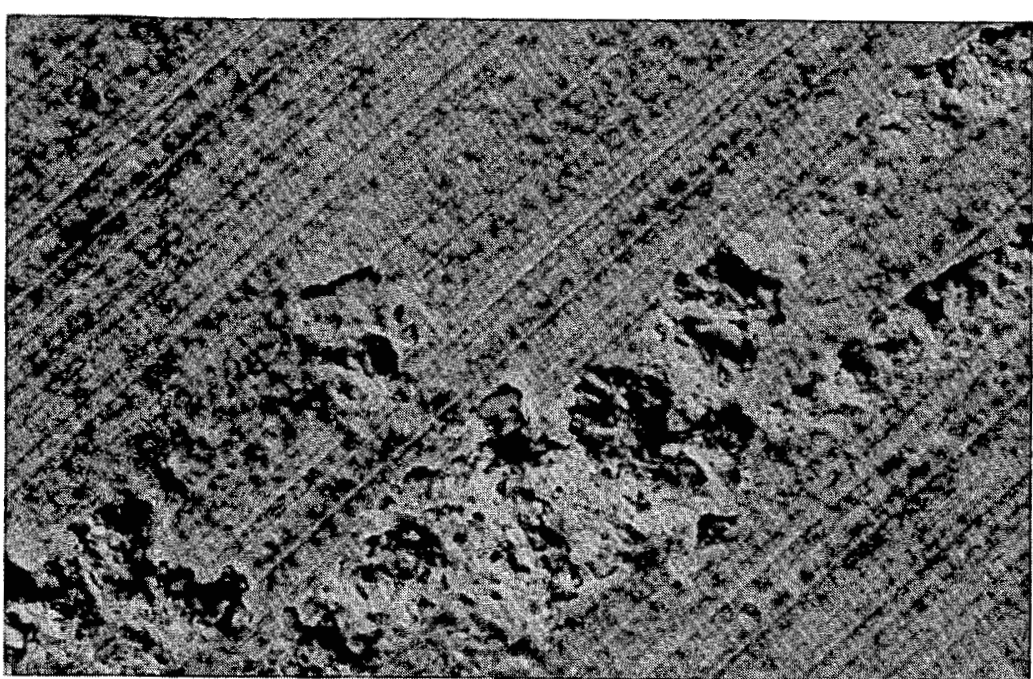

(b)

Fig. 40. Pitting and oxide growth patterns of perc coolant-machined part 5740 shown 225 d after final machining on the $O C$ at $45^{\circ}$ Magnification: (a) $3000 \mathrm{X}$, (b) $1000 \mathrm{X}$, (c) $300 \mathrm{X}$. 


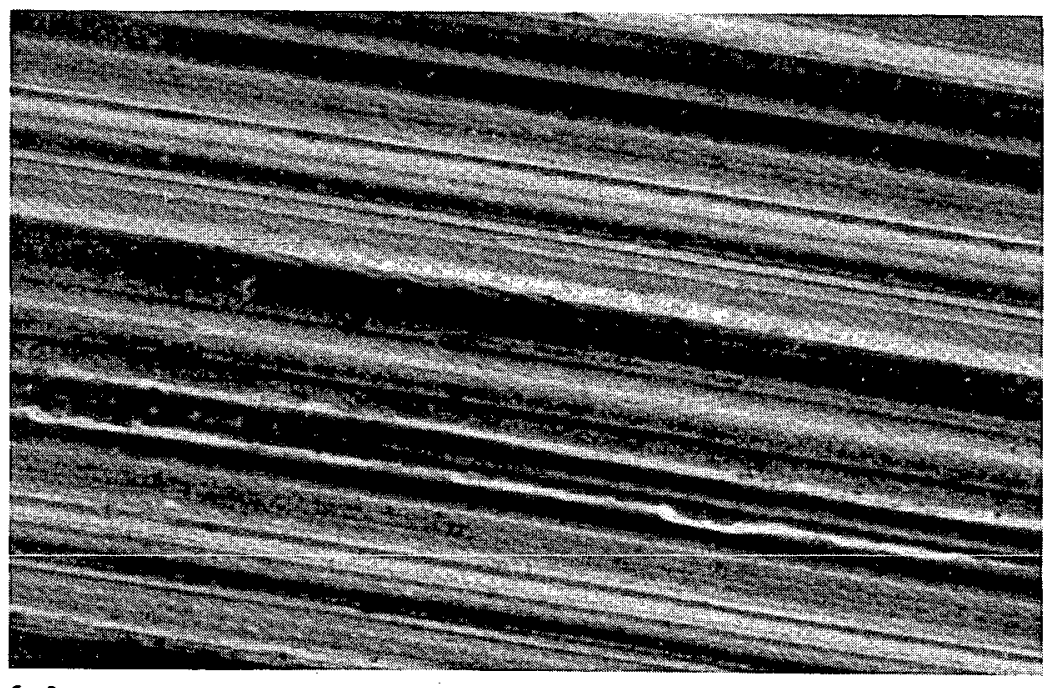

(a)

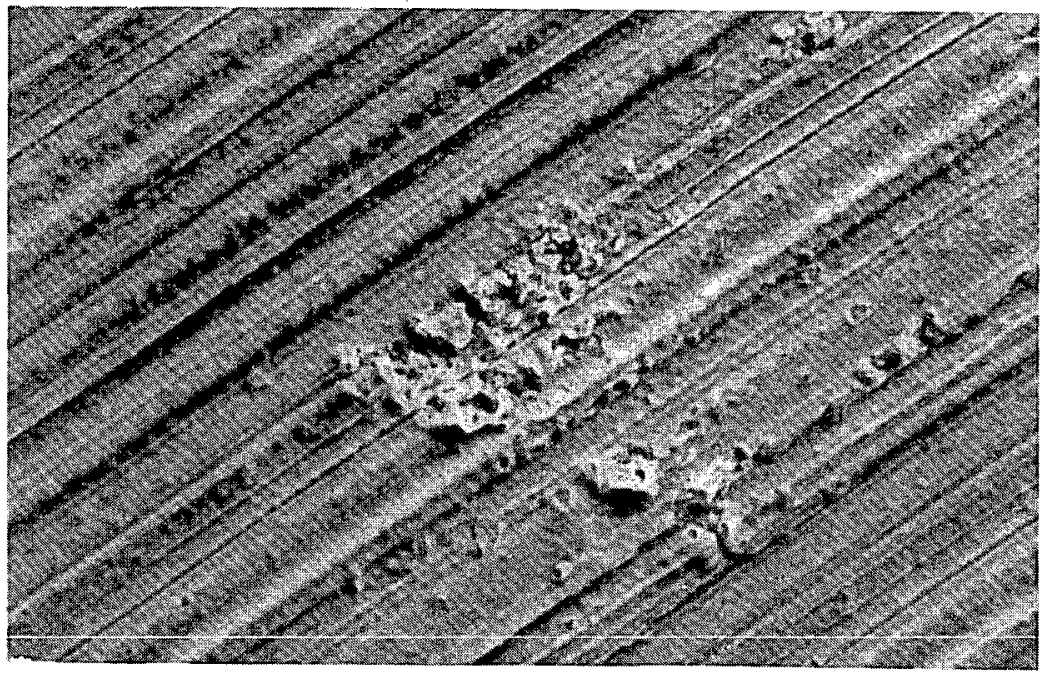

(c)

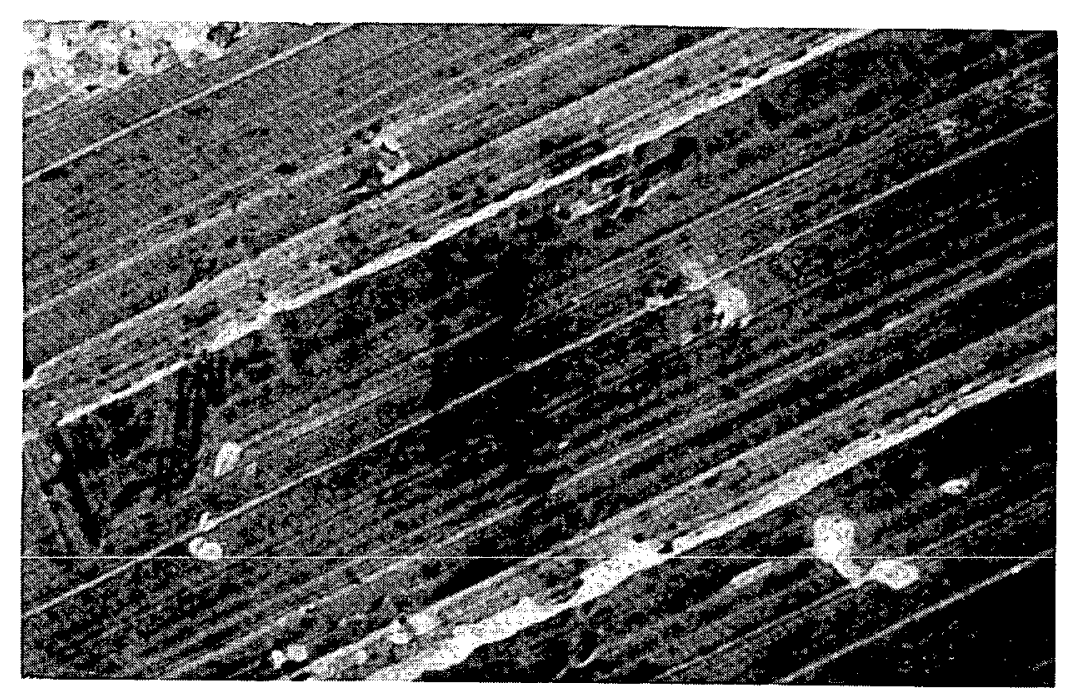

(b)

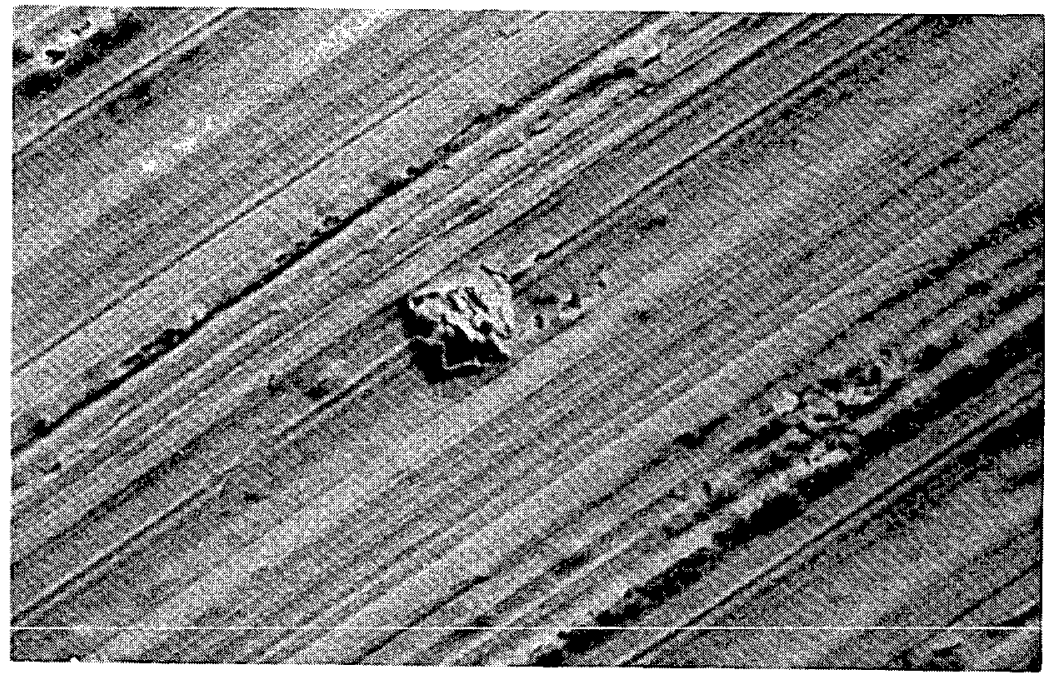

(d)

Fig. 41. Surface morphology vs time after final machining-boron coolant. All magnifications are 1000X. Taken after (a) $30 \mathrm{~d}$, (b) $45 \mathrm{~d}$, (c) $75 \mathrm{~d}$, (d) $225 \mathrm{~d}$. 


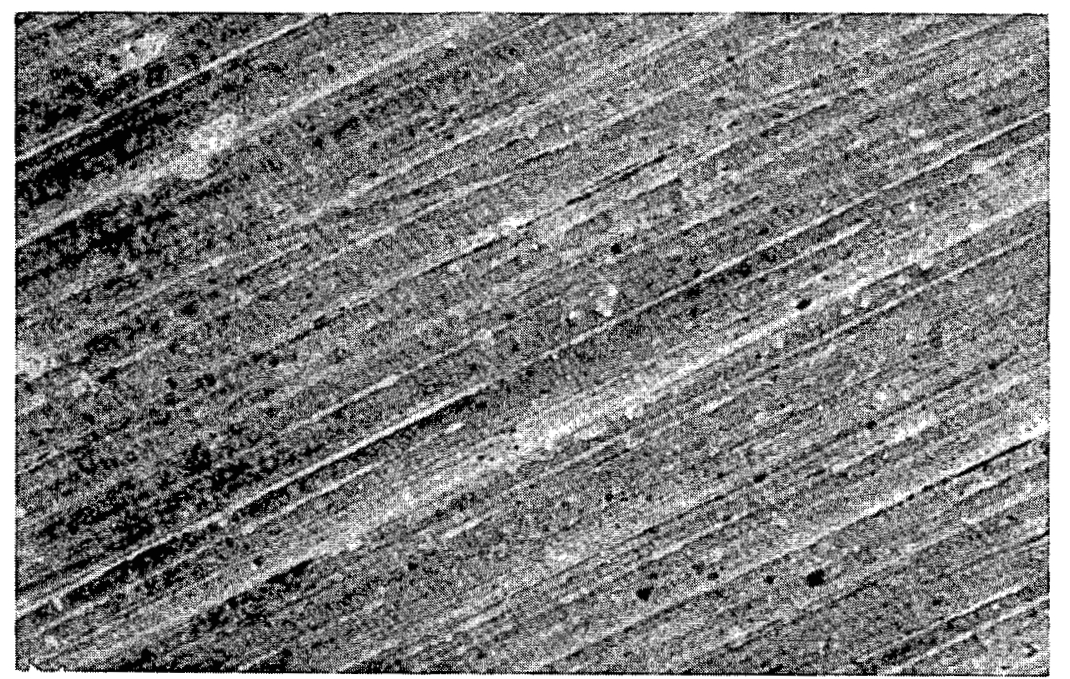

(a)

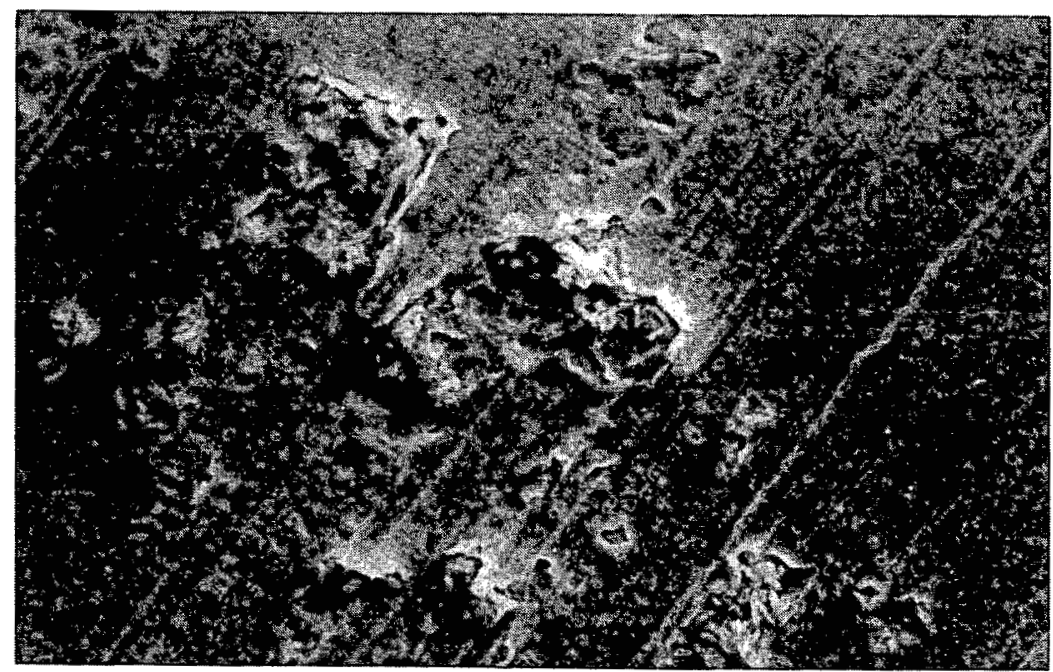

(c)

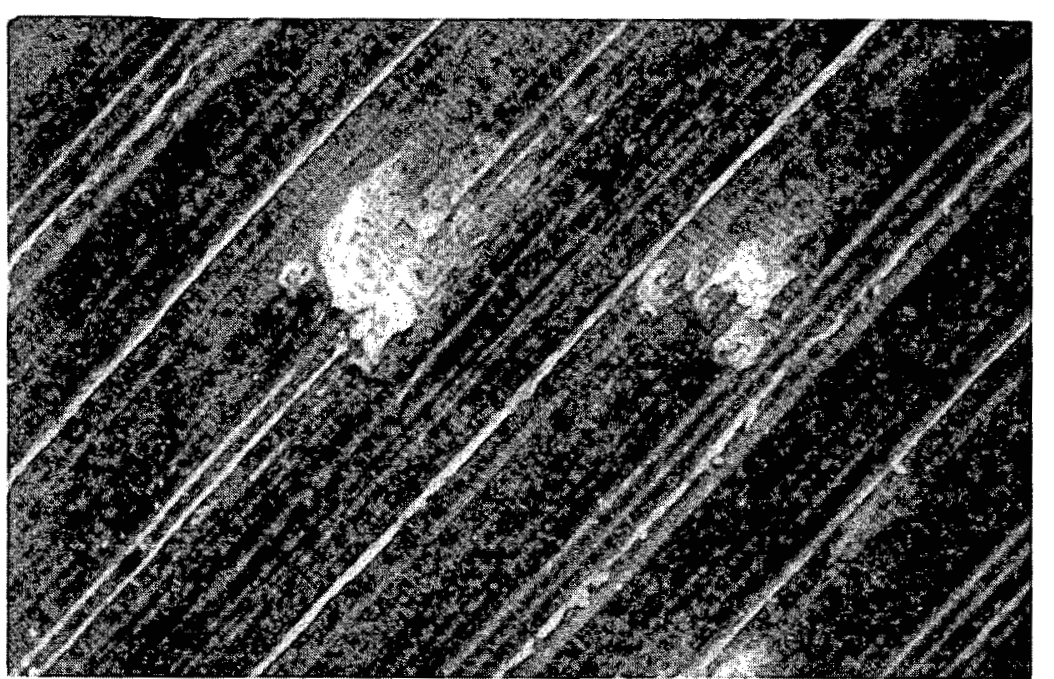

(b)

Fig. 42. Surface morphology vs time after final machining--perchloroethylene coolant. All magnifications are 1000X. Taken after (a) $45 \mathrm{~d}$, (b) $75 \mathrm{~d}$, (c) $225 \mathrm{~d}$. 


\section{ACCELERATED CORROSION TESTING}

Accelerated corrosion testing was used to determine if there were gross differences in the atmospheric corrosion properties of the enriched uranium machined by the different coolants. The accelerated atmospheric corrosion test consisted of exposing the samples to an alternating humidity cycle at $66^{\circ} \mathrm{C}$ for approximately 1 month. The humidity cycle was $55 \mathrm{~min}$ at $100 \%$ relative humidity, $55 \mathrm{~min}$ at $50^{\circ}$ relative humidity, and a 5 -min interval between humidity changes. This alternating condensing/drying cycle causes higher corrosion rates than exposure at a constant humidity.

Prior to exposure, the samples were cleaned with acetone, rinsed with alcohol, and air dried. Each sample was weighed independently by different technicians to the nearest $0.01 \mathrm{mg}$.

Because of the varying curvature of the samples, the exposed surface area was calculated from thickness, weight, and density rather than from direct dimensional measurement. Also, the edges of most of the specimens contained burrs. If the as-received surface had not been the major concern in the experiment, these burrs would have been removed. Because the purpose of this experiment was to compare coolants and because all samples were handled in the same manner, these perturbations should not have affected the overall results.

After exposure, the samples were washed with alcohol and weighed. A large percentage of the samples had a weight loss, which was attributed to oxide spalling. These weight losses precluded calculating corrosion rates from weight-gain data; therefore, weight-loss data were used. This method of calculating the corrosion rates biases the calculated rates toward the high side because all corrosion is assumed to occur during the 30-d exposure to the alternating humidity environment; in reality, some oxide formed during the storage period.

The basic procedures of ASTM G1-81, "Preparing, Cleaning, and Evaluating Corrosion Test Specimens," 3 were used to determine corrosion rates. The cleaning solution was 50 vol $\%$ nitric acid- $50 \%$ deionized water at room temperature. Immersion time was $3 \mathrm{~min}$, and the cycle was repeated five times. The first cleaning cycle removed the oxide without significant loss of base metal, and correction factors were not required for base metal removal.

The calculated corrosion rates for the various test conditions are presented in Table 8 . The average corrosion rate of the samples that were similar to those sent to Rocky Flats and machined in the propylene glycol-water-borax coolant was $0.45 \mathrm{mil} /$ year. This rate is similar to that of the samples that were machined in this coolant and stored for 1 month: 0.58 and $0.49 \mathrm{mil} /$ year. The corrosion rates of samples machined from the enriched uranium parts that had the standard treatment and those which were stored for an additional month in the Rocky Flats bags were analyzed statistically using a two-factorial design. The main effects were coolant (perc-mineral oil or propylene glycol-water-borax) 
and treatment history (standard or standard plus 1 month in Rocky Flats bags). Specimen location within a part was used as a blocking factor. At a $95 \%$ confidence level, only the choice of coolant had a significant effect.

Table 8. Corrosion rates of enriched uxanium in alternating humidity environment

\begin{tabular}{|c|c|c|c|c|c|}
\hline \multirow[b]{2}{*}{ Condition } & \multirow[b]{2}{*}{ Coolant } & \multicolumn{4}{|c|}{ Corrosion rate (mil/year) } \\
\hline & & $\overline{\text { Mouth }}$ & $45^{\circ}$ & Pole & Average \\
\hline $\begin{array}{l}\text { Like Rocky Flats } \\
\text { test parts }(5715)\end{array}$ & Boron & 0.37 & 0.44 & 0.53 & 0.45 \\
\hline Standard $(5692,5713)$ & Boron & $\begin{array}{l}0.64 \\
0.59\end{array}$ & $\begin{array}{l}0.66 \\
0.60\end{array}$ & $\begin{array}{l}0.39 \\
0.57\end{array}$ & 0.58 \\
\hline Standard $(5725,5726)$ & Perc & $\begin{array}{l}0.77 \\
0.77\end{array}$ & $\begin{array}{l}0.73 \\
0.96\end{array}$ & $\begin{array}{l}0.90 \\
0.82\end{array}$ & 0.83 \\
\hline $\begin{array}{l}\text { Standard }+1 \text { month } \\
\text { in Rocky Flats bags } \\
(5720,5722)\end{array}$ & Boron & $\begin{array}{l}0.39 \\
0.50\end{array}$ & $\begin{array}{l}0.71 \\
0.40\end{array}$ & $\begin{array}{l}0.56 \\
0.38\end{array}$ & 0.49 \\
\hline $\begin{array}{l}\text { Standard }+1 \text { month } \\
\text { in Rocky F1ats bags } \\
(5730,5733)\end{array}$ & Perc & $\begin{array}{l}1.00^{a} \\
0.60\end{array}$ & $\begin{array}{l}0.45 \\
0.75\end{array}$ & $\begin{array}{l}0.53 \\
0.62\end{array}$ & 0.66 \\
\hline
\end{tabular}

${ }^{a}$ Severe localized corrosion.

Additional statistical analysis (see Appendix) indicated that there was a small but significant decrease in the corrosion rate of the 1-month-storage sample compared with the standard treatment samples. This difference may be due to improvements in deburring the samples which were instituted after all the standard treatment samples had been run. This improvement decreased the actual surface area in a way not easily quantifiable.

The corrosion rate of the enriched uranium that was machined with the new propylene glycol-water-borax mixture was $0.23 \pm 0.14 \mathrm{mil} /$ year lower than that of the samples machined with the old perc-mineral oil coolant. This slight difference, although insignificant from a practical viewpoint, is in the desired direction and shows that substituting propylene glycol-water-borax coolant for perc-mineral oil coolant will not deleteriously affect the corrosion properties of enriched uranium.

A visual examination of the exposed specimens confirmed the differences in the corrosion characteristics of the specimens machined in the two coolants. Twenty-five percent of the specimens that were machined with the old perc-mineral oil coolant displayed small localized 
areas with loose corrosion product (Fig. 43), whereas none of the samples that were machined with the new propylene glycol-water-borax mixture displayed this type of corrosion.

The areas of localized corrosion were evident after a few days' exposure to the test environment and did not appear to grow as the test continued. No efforts were made to determine the cause of these localized corrosion areas; however, they were probably caused by incomplete removal of the chloride contaminant during cleaning operations.

In summary, the corrosion properties of enriched uranium machined in the new propylene glycol-water-borax coolant are superior to those of enriched uranium machined in the old perc-mineral oil coolant. This conclusion is based on both weight-loss data and visual appearance of the exposed specimens.

\section{COOLANT CHARACTERIZATION}

To monitor the pickup of contaminants in the coolant and to determine whether the coolant was changing over the course of the machining of our experimental parts, some analyses were run on two $50-\mathrm{mL}$ samples of the boron coolant after machining the first, fourth, seventh, and the tenth parts. These analyses included grams of uranium per gram $(\mathrm{gU} / \mathrm{g}), \mathrm{pH}$, boron by ICP, propylene glycol-to-water ratio, and ion chromatography for nitrite, nitrate, chloride, and sulfate. The perchloroethylene coolant was collected after the first, third, and fifth parts were machined and the $\mathrm{gU} / \mathrm{g}$ was determined. The data are displayed in Table 9.

Table 9. Coolant data

\begin{tabular}{|c|c|c|c|c|c|c|c|c|c|}
\hline \multirow[b]{2}{*}{ Part } & \multirow[b]{2}{*}{ Coolant } & \multicolumn{6}{|c|}{ Parts per million } & \multirow[b]{2}{*}{$\mathrm{pH}$} & \multirow{2}{*}{$\begin{array}{c}\text { Glycol } \\
\text { water }\end{array}$} \\
\hline & & $\overline{\mathrm{gU} / \mathrm{g}}$ & Boron & $\mathrm{Cl}$ & $\mathrm{NO}_{2}$ & $\mathrm{NO}_{3}$ & $\overline{\mathrm{SO}_{4}}$ & & \\
\hline 5700 & Boron & 36.3 & 8600 & 32 & 700 & 46 & 26 & 7.7 & $41 / 59$ \\
\hline 5692 & Boron & 27.3 & 8800 & 28 & 1000 & 34 & 24 & 7.8 & $39 / 61$ \\
\hline 5727 & Boron & 28.5 & 8600 & 28 & 740 & 33 & 23 & 7.8 & $43 / 57$ \\
\hline 5715 & Boron & 29.4 & 8200 & 27 & 710 & 27 & 22 & 7.8 & $41 / 59$ \\
\hline 5740 & Perc & 38.1 & & & & & & & \\
\hline 5739 & Perc & 37.8 & & & & & & & \\
\hline 5733 & Perc & 38.7 & & & & & & & \\
\hline
\end{tabular}

Note: Machining order--5700, 1st; 5692, 4th; 5727, 7th; and 5715, 10th. $5740,1 \mathrm{st} ; 5739,3 \mathrm{rd}$; and $5733,5 \mathrm{th}$. 


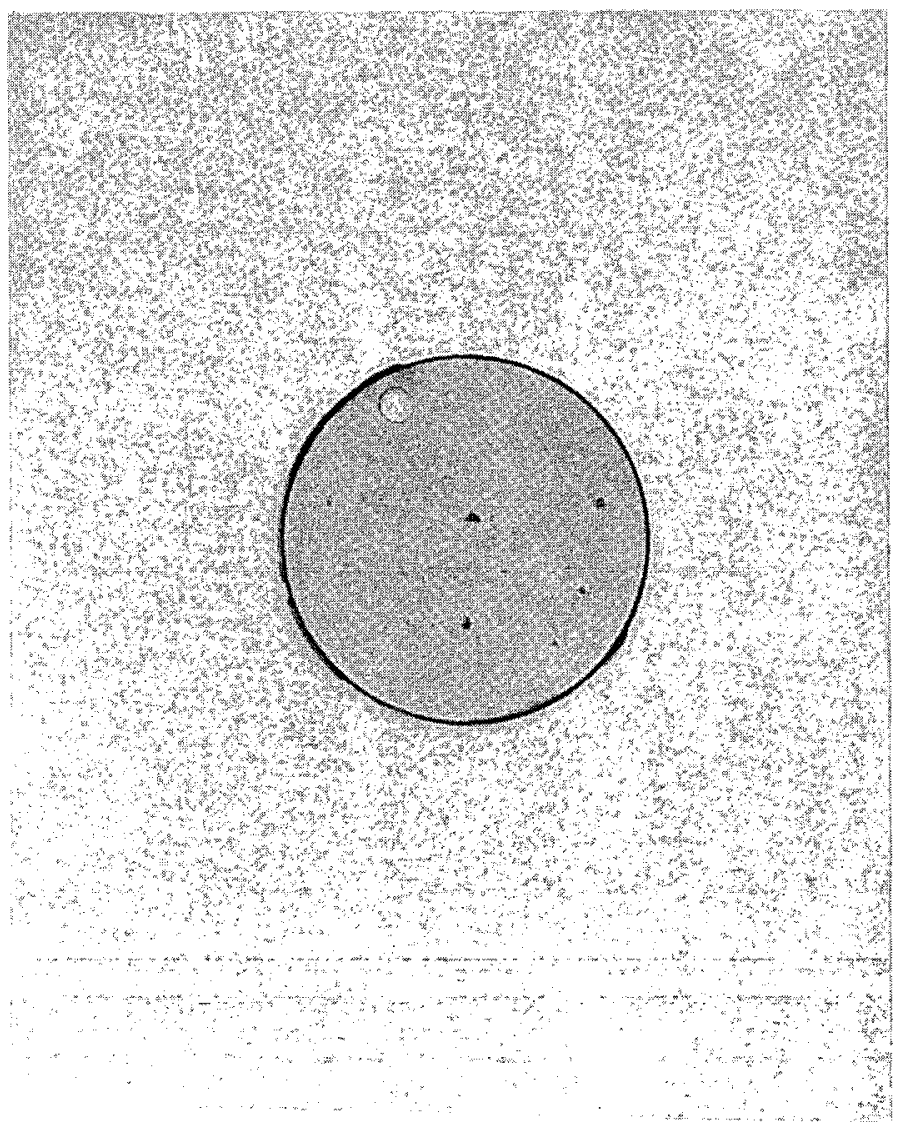

(a)

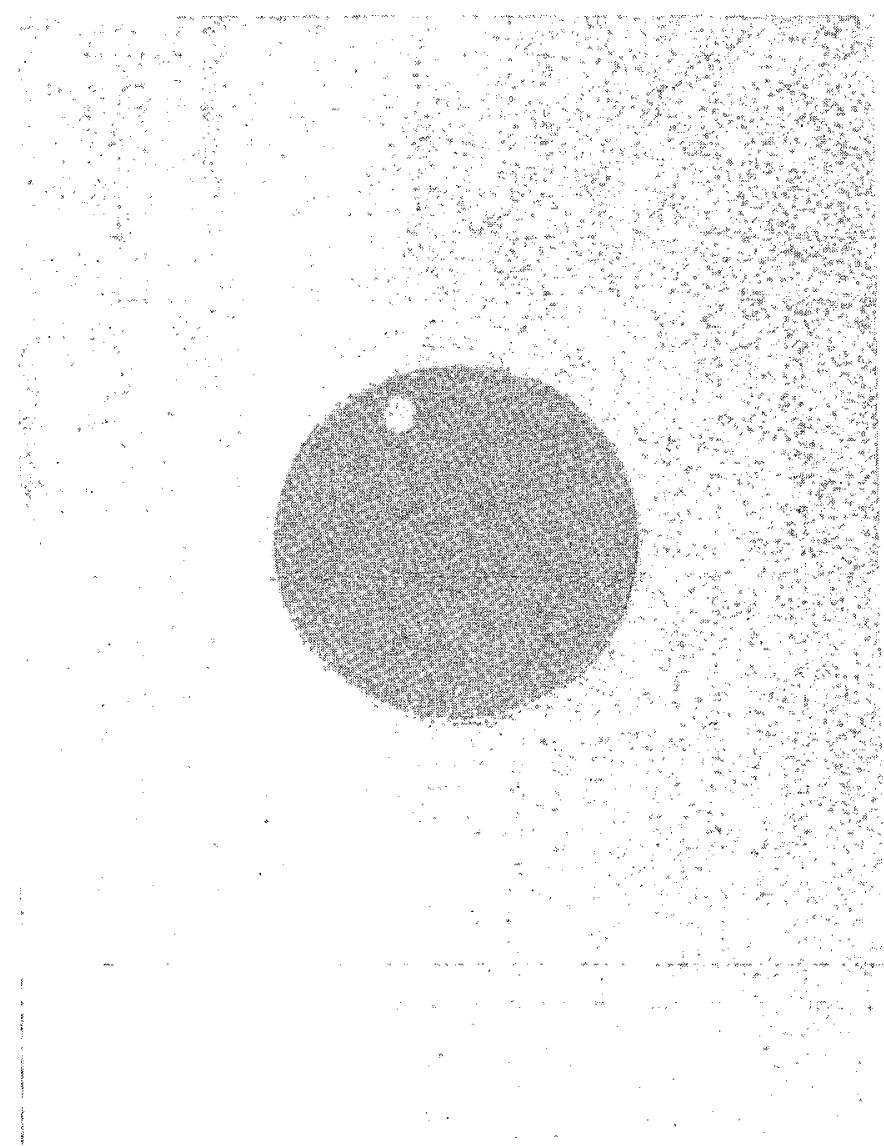

(b)

Fig. 43. Samples machined with perc coolant displayed more localized corrosion than did samples machined with the boron coolant. (a) Perc, 30-d exposure; (b) boron, 30-d exposure. 
The only consistent trends in the Table 9 data are decreases in the chloride, nitrate, and sulfate ions with time. The increase in nitrite after the fourth part seems odd. However, the nominal level is $1000 \mathrm{ppm}$ of nitrite as an inhibitor. A favorable note is that the quantity of uranium in the boron coolant did not appear to increase with time and was less than that measured in the perc coolant. The boron level in the coolant is very important, and it appeared to remain stable over the short period of ten parts machined for this study.

A Freon extraction was performed on the coolant associated with parts 5715 and 5727 . The former produced $4 \mathrm{mg}$ of residues for $110 \mathrm{~mL}$ of coolant. Infrared (IR) analysis showed mineral oil plus unidentified material. The latter produced $48 \mathrm{mg}$ of residues for $114 \mathrm{~mL}$ of coolant. An IR analysis indicated that mineral oil was the major component. This amount of mineral oil could easily be some pickup from the perc coolant that had been used in the machine previously. 


\section{CONCLUSIONS}

Boron residues on the final-finished, boron coolant-machined parts were found to average $15 \pm 3 \mathrm{ng} / \mathrm{cm}^{2}$. Inside contour surfaces averaged somewhat higher than outside contour surfaces. Overall, this level of boron is not considered a problem for any subsequent processing of the parts. General contamination on both perc-machined and boron coolantmachined parts was found to be very similar. Some differences observed were greater boron and carbon on the boron-coolant parts and greater chlorine on the perc-coolant parts. Uranium on the surface of all parts was in the +4 oxidation state. Total oxygen on the surface increased equally for both types of parts with storage time.

After $225 \mathrm{~d}$ of exposure, statistically different corrosion rates were found for enriched uranium surfaces machined by the two different coolants and exposed to the normal environmental conditions of the $\mathrm{Y}-12$ Plant. Oxide growth on parts machined with the perc coolant progressed at a rate of $1.6 \mathrm{~nm} / \mathrm{d}$ vs $1.0 \mathrm{~nm} / \mathrm{d}$ for the boron coolant-machined parts. Under accelerated corrosion conditions, a slightly higher corrosion rate was found for the perc-cut parts-0.75 mil/year $(52 \mathrm{~nm} / \mathrm{d})$ vs 0.51 $\mathrm{mil} /$ year $(35 \mathrm{~nm} / \mathrm{d})$ for the boron coolant-cut parts.

During the relatively short term of ten parts machined in the boron coolant, no serious contamination problems of the coolant were discovered, and the boron level remained reasonably constant.

In summary, corrosion resistance of enriched uranium machined with the aqueous propylene glycol-borax coolant is better than that of enriched uranium machined with the perc-mineral oil coolant. The boron residues on the final-finished parts machined using the borax-containing coolant are not sufficient to cause problems in further processing. All evidence indicates that the enriched uranium surfaces machined using the borax-containing coolant will be as satisfactory as those machined using the perc coolant. 


\section{ACKNOWLEDGMENTS}

The success of this project depended heavily on the cooperation and efforts of numerous others in addition to the authors. The authors received excellent cooperation and help throughout the course of the project and would like to express their appreciation to the following: Brenda Disney, Shirley Cox, and Gerald Lankford for planning and following the scheduling of parts; Bruce Creekmore, Danny Cunningham, and Mike Self for keeping up with parts, schedules, and samples; Tom Sparks, Wentz Dickenson, and Dan Skidmore, who made sure parts were cut properly, machines were ready, and ensured that parts were cut on schedule and to our satisfaction; Pat Hair, who prepared the requisitions for Plant Laboratory work and received the data; Joe Hamilton for coordinating the Plant Laboratory work and for useful discussions concerning analyses; George Larson and Rick Slagle for ICP planning, analyses, and interpreting the ICP data; and John Shelton for the statistical analyses and for writing the Appendix. 


\section{REFERENCES}

1. G. C. Allen and P. M. Tucker, J. Chem. Soc. Dalton Trans. 470, (1973).

2. J. A. Happe, C. A. Colmenares, T. McCreary, and G. A. Somorjai, SUBWOG 12 Meeting at GEND, St. Petersburg, Fla., Feb. 16-18, 1977.

3. Annual Book of ASTM Standards, vol. 10, American Society for Testing and Materials, Philadelphia, 1981. 


\section{APPENDIX}

\section{STATISTICAL ANALYSIS OF DATA}

\section{A.1 SURFACE CONTAMINATION}

\section{A.1.1 Boron Results}

Because of the variability and inconsistency in the bulk boron data, the approach to assessing surface boron by subtracting the average bulk boron from the boron levels found in the chips appears to be unreliable. As the report suggests, acid leaching is probably the most reliable approach for assessing surface boron. Six-cm-diam disks were cut from each of $n=6$ parts machined with the boron coolant and from each of $n=5$ parts machined with the perchloroethylene (perc) coolant. The disks were acid leached to remove surface boron, and the leachant was measured for boron content by inductively coupled plasma emission spectroscopy (ICP). The acid leaching results are as follows:

\begin{tabular}{llc} 
Coolant & Part & $\begin{array}{c}\text { Surface boron } \\
\left(\mathrm{ng} / \mathrm{cm}^{2}\right)\end{array}$ \\
\hline Boron & 5715 & 12 \\
Boron & 5692 & 19 \\
Boron & 5713 & 16 \\
Boron & 5720 & 16 \\
Boron & 5722 & 13 \\
Boron & 5727 & 16 \\
Perc & 5726 & $a$ \\
Perc & 5730 & $a$ \\
Perc & 5733 & $a$ \\
Perc & 5739 & $a$ \\
Perc & 5740 & $a$ \\
\hline
\end{tabular}

$a_{\text {Below ICP detection limit. }}$

Since the surface boron results for the perc coolant are all below the detection limit of the ICP spectroscopy, it is not possible to statistically compare the levels of surface boron for the two coolants. It is possible, however, to estimate the mean surface boron level for the boron coolant. A 95\% confidence interval for this mean surface boron level is $15.3 \pm 2.6 \mathrm{ng} / \mathrm{cm}^{2}$.

\section{A.1.2 ESCA Results}

Electron spectroscopy (ESCA) was used to assess the surface conditions of the machined parts in terms of three atomic concentration ratios: $O(1 \mathrm{~s}) \mathrm{HBE} / O(1 \mathrm{~s}) \mathrm{LBE}, O(1 \mathrm{~s}) / \mathrm{U}(4 f)$, and $C(1 \mathrm{~s}) / U(4 f)$. These three ratios were determined at each of three positions (pole, $45^{\circ}$, and mouth) 
on each of twelve parts. An analysis of variance was performed to statistically compare the means of seven handling treatments, as well as to compare the means at the three positions (pole, $45^{\circ}$, and mouth) and to assess any possible interaction between treatment and position. The treatment means and the analysis of variance results are given in Tables A.1 and A.2 respectively.

Taking as statistically significant any F-test for which the p-value (probability $>F$ ) falls below $p=0.05$, we can conclude the following:

1. For both coolants, the means of each of the three ratios $0 / 0,0 / U$, and $\mathrm{C} / \mathrm{U}$ increase significantly with storage time. This increase can be modeled by straight lines for all three ratios. For the $O / U$ and $\mathrm{C} / \mathrm{U}$ ratios, no matter which coolant is considered, the least-squares regression lines are

$$
\begin{aligned}
& O / U=2.734+0.016 \text { (storage time, } d) \text {, } \\
& C / U=2.972+0.044 \text { (storage time, } d) .
\end{aligned}
$$

For the $\mathrm{O} / \mathrm{O}$ ratio, statistical evidence suggests that the two coolants have different regression lines:

Boron coolant:

$$
\mathrm{O} / \mathrm{O}=0.944+0.012 \text { (storage time, d), }
$$

Perc coolant:

$$
0 / O=0.027 \text { (storage time, d). }
$$

Thus the two coolants behave similarly with respect to either their $\mathrm{O} / \mathrm{U}$ or $\mathrm{C} / \mathrm{U}$ ratios as a function of storage time. However, for the $0 / O$ ratio, the least-squares regression lines indicate that the $0 / O$ ratio is lower for the perc coolant than for the boron coolant for less than $64 \mathrm{~d}$ of storage, but the $0 / 0$ ratio is greater for the perc coolant than for the boron coolant for more than $64 d$ of storage.

2. The means of each of three ratios do not differ significantly among the three sampling positions (pole, $45^{\circ}$, and mouth).

3. There is no evidence of any interaction between position and treatment for any of the three ratios.

See Figs. A.1, A.2, and A.3 for plots of the $0 / 0,0 / U$, and $C / U$ treatment means. 
Table A.1. ESCA sample means

\begin{tabular}{|c|c|c|c|c|c|c|c|}
\hline Treatment & Coolant & Handling & $\begin{array}{l}\text { Storage } \\
\text { time } \\
\text { (d) }\end{array}$ & $\mathbf{n}$ & $\overline{0 / 0}$ & $\frac{\text { Means }}{0 / \mathrm{U}}$ & $\overline{C / U}$ \\
\hline 1 & Boron & $\begin{array}{r}\text { Same as Rocky } \\
\text { Flats Plant }\end{array}$ & 30 & 3 & 1.34 & 3.08 & 5.42 \\
\hline 2 & Boron & Standard & 45 & 6 & 1.40 & 3.60 & 5.45 \\
\hline 3 & Perc & Standard & 45 & 6 & 1.44 & 3.43 & 4.32 \\
\hline 4 & Boron & $\begin{array}{c}\text { Standard }+ \\
1 \text { month }\end{array}$ & 75 & 6 & 1.94 & 4.10 & 6.88 \\
\hline 5 & Perc & $\begin{array}{c}\text { Standard }+ \\
1 \text { month }\end{array}$ & 75 & 6 & 1.62 & 3.70 & 5.23 \\
\hline 6 & Boron & $\begin{array}{l}\text { Standard }+ \\
6 \text { months }\end{array}$ & 225 & 3 & 3.64 & 6.05 & 10.97 \\
\hline 7 & Perc & $\begin{array}{l}\text { Standard }+ \\
6 \text { months }\end{array}$ & 225 & 6 & 6.10 & 6.47 & 14.11 \\
\hline
\end{tabular}

\section{A.2 OXIDE DEPTH RESULTS}

The ion microprobe mass analyzer (IMMA) was used to measure the depth of the oxide corrosion layer on coupons cut from each of six locations [three positions (pole, $45^{\circ}$, and mouth) on two surfaces (IC and $O C)]$ on each of twelve parts. An analysis of variance was performed to look for effects on the mean oxide depth due to the different handling treatments, the three positions, or the two surfaces, and to look for any interactions among the three factors. The analysis of variance results and the appropriate sample means are given in Tables A.3 and A.4, respectively.

The mean oxide depth increases significantly with storage time on both the parts machined with the boron coolant and the parts machined with the perc coolant. This increase in oxide depth can be modeled as a straight-line function of storage time, but the equation of the line depends on the coolant type and on the measurement position (IC or OC; pole, $45^{\circ}$, or mouth) (see Fig. A.4).

Even though the equations for the lines depicting the relationship between oxide depth and storage time do change with coolant and measurement position, a reasonable way to approximate the overall relationship between the oxide depth on the parts and storage time is to fit one regression line using all the data for the perc-machined parts and 
Table A.2. ESCA analysis of variance

\begin{tabular}{|c|c|c|c|c|c|}
\hline \multirow{2}{*}{\multicolumn{2}{|c|}{ Source }} & \multirow[b]{2}{*}{ D.F. } & \multicolumn{3}{|c|}{ Probability $>F^{a}$} \\
\hline & & & $0 / 0$ & $0 / U$ & $\mathrm{C} / \mathrm{U}$ \\
\hline \multicolumn{2}{|c|}{ Treatment $b$} & 6 & & & \\
\hline & $\begin{array}{l}\text { Storage time } \\
\text { Linear } \\
\text { Quadratic }\end{array}$ & & $\begin{array}{l}0.0014 \\
0.0005 \\
0.5968\end{array}$ & $\begin{array}{l}0.0003 \\
0.0001 \\
0.7345\end{array}$ & $\begin{array}{l}0.0055 \\
0.0020 \\
0.9287\end{array}$ \\
\hline & Coolant & & 0.1005 & 0.8109 & 0.9177 \\
\hline & $\begin{array}{l}\text { Storage time X coolant } \\
\text { Linear X coolant } \\
\text { Quadratic X coolant }\end{array}$ & & $\begin{array}{l}0.0619 \\
0.0275 \\
0.3659\end{array}$ & $\begin{array}{l}0.3423 \\
0.2019 \\
0.4673\end{array}$ & $\begin{array}{l}0.2629 \\
0.1283 \\
0.6082\end{array}$ \\
\hline & $\begin{array}{l}\text { Linear storage time } \\
\text { (boron coolant) }\end{array}$ & & 0.0215 & 0.0008 & 0.0420 \\
\hline e. & $\begin{array}{l}\text { Quadratic storage time } \\
\text { (boron coolant) }\end{array}$ & & 0.9147 & 0.3817 & 0.9183 \\
\hline & $\begin{array}{l}\text { Cubic storage time } \\
\text { (boron coolant) }\end{array}$ & & 0.8063 & 0.6364 & 0.7892 \\
\hline Par & $t($ treatment $)$ & 5 & & & \\
\hline & ition & 2 & 0.8585 & 0.2509 & 0.2664 \\
\hline & ition $\mathrm{X}$ treatment & 12 & 0.8131 & 0.0914 & 0.1864 \\
\hline & idual & $\underline{10}$ & & & \\
\hline To & & 35 & & & \\
\hline
\end{tabular}

$a_{\text {An }}$ analysis of variance was also performed on the rank transformed data, because the response variables are ratios that do not follow a normal distribution. Results for the analysis of variance on the original data and on the rank transformed data were similar (taking $\alpha=0.05$ ).

$b_{\text {Contrasts }} a, b$, and $c$ involve treatments 2 through 7 only. Contrasts $d, e$, and $f$ involve treatments $1,2,4$, and 6 . 


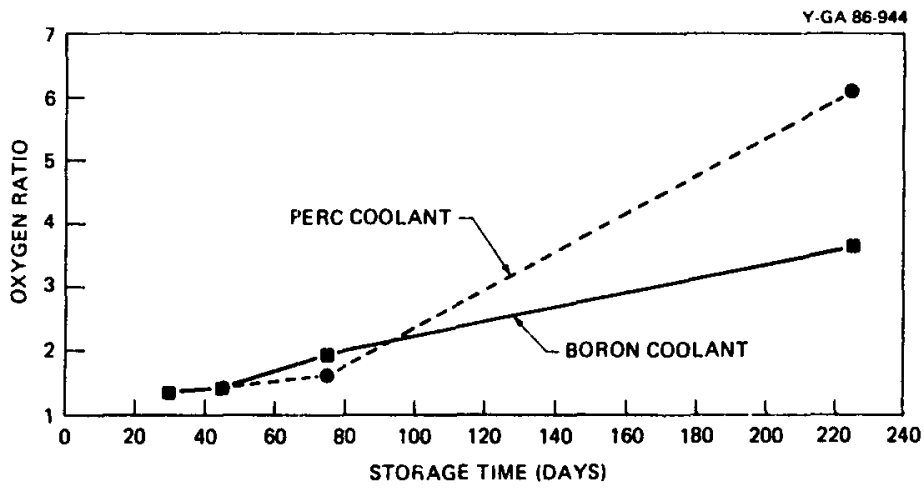

Fig. A.1. Plot of $O(1 \mathrm{~s}) \mathrm{HBE} / \mathrm{O}(19) \mathrm{LBE}$ treatment means versus days of storage.

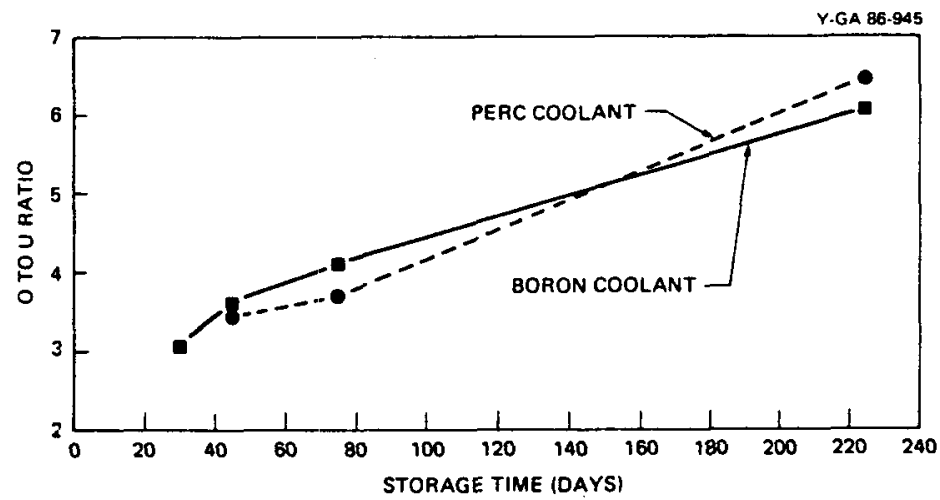

Fig. A.2. Plot of $O(1 s) / U(4 f)$ treatment means versus days of storage.

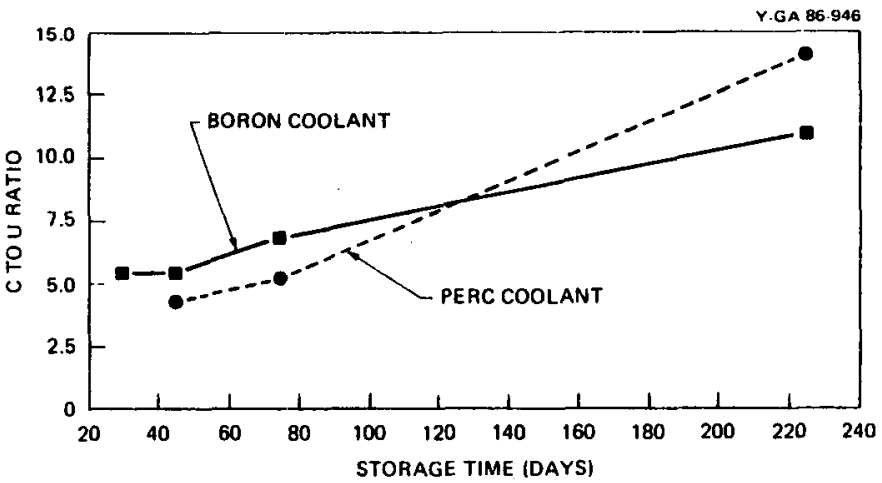

Fig. A.3. Plot of C(1s)/U(4f) treatment means versus days of storage. 
Table A.3. Oxide depth analysis of variance

\begin{tabular}{lcc}
\hline \multicolumn{1}{c}{ Source } & D.F. & Probability $>$ F \\
\hline $\begin{array}{l}\text { Treatment } \\
\text { a. } \begin{array}{c}\text { Storage time } \\
\text { Linear } \\
\text { Quadratic }\end{array}\end{array}$ & 6 & \\
b. Coolant & & 0.0001 \\
c. Storage time X coolant & 0.0001 \\
$\quad$ Linear X coolant & 0.1078 \\
Part (treatment) & & 0.0023 \\
Position & 5 & 0.0043 \\
Surface & 2 & 0.0017 \\
Position X surface & 1 & 0.1940 \\
Treatment X position & 2 & 0.0017 \\
Treatment X surface & 12 & 0.0025 \\
Treatment X position X surface & 12 & 0.0020 \\
Residual & 25 & 0.0023 \\
Total & 71 & 0.0001 \\
\hline
\end{tabular}

Note: Contrasts a, b, and c involve treatments 2 through 7 only.

separately fit a second regression line using all the data for the boron-machined parts (i.e., combine data from all six measurement positions) (see Fig. A.5). The least-squares regression lines fitted using these combined data are:

Boron coolant:

Oxide depth $(\mathrm{nm})=62.983+0.983$ (storage time, d),

Perc coolant:

Oxide depth $(\mathrm{nm})=42.398+1.638$ (storage time, d). 
Table A.4. Oxide depth sample means

\begin{tabular}{|c|c|c|c|c|c|}
\hline Treatment & Coolant & Handling & $\begin{array}{l}\text { Storage } \\
\text { time } \\
\text { (d) }\end{array}$ & $n$ & $\begin{array}{l}\text { Mean } \\
\text { oxide } \\
\text { depth } \\
(\mathrm{nm})\end{array}$ \\
\hline 1 & Boron & Same as Rock & 30 & 6 & 63.9 \\
\hline 2 & Boron & Standard & 45 & 12 & 101.0 \\
\hline 3 & Perc & Standard & 45 & 12 & 114.0 \\
\hline 4 & Boron & $\begin{array}{c}\text { Standard + } \\
1 \text { month }\end{array}$ & 75 & 12 & 162.7 \\
\hline 5 & Perc & $\begin{array}{c}\text { Standard + } \\
1 \text { month }\end{array}$ & 75 & 12 & 167.8 \\
\hline 6 & Boron & $\begin{array}{l}\text { Standard + } \\
6 \text { months }\end{array}$ & 225 & 6 & 273.1 \\
\hline \multirow[t]{2}{*}{7} & Perc & $\begin{array}{l}\text { Standard }+ \\
6 \text { months }\end{array}$ & 225 & 12 & 410.6 \\
\hline & Coolant & Position & Surface & $\begin{array}{l}\text { Storage } \\
\text { time } \\
\text { (d) }\end{array}$ & $\begin{array}{l}\text { Mean } \\
\text { oxide } \\
\text { depth } \\
(\mathrm{nm})\end{array}$ \\
\hline 1 & Boron & Mouth & IC & 30 & 109.0 \\
\hline 2 & Boron & Mouth & IC & 45 & 84.0 \\
\hline 4 & Boron & Mouth & IC & 75 & 128.5 \\
\hline 6 & Boron & Mouth & IC & 225 & 164.5 \\
\hline 1 & Boron & Mouth & OC & 30 & 82.5 \\
\hline 2 & Boron & Mouth & OC & 45 & 133.0 \\
\hline 4 & Boron & Mouth & OC & 75 & 204.7 \\
\hline 6 & Boron & Mouth & OC & 225 & 401.0 \\
\hline 1 & Boron & Pole & IC & 30 & 36.5 \\
\hline 2 & Boron & Pole & IC & 45 & 89.0 \\
\hline 4 & Boron & Pole & IC & 75 & 175.0 \\
\hline 6 & Boron & Pole & IC & 225 & 149.0 \\
\hline 1 & Boron & Pole & $O C$ & 30 & 53.0 \\
\hline 2 & Boron & Pole & $O C$ & 45 & 100.0 \\
\hline 4 & Boron & Pole & $O C$ & 75 & 195.0 \\
\hline 6 & Boron & Pole & OC & 225 & 260.3 \\
\hline 1 & Boron & $45^{\circ}$ & IC & 30 & 61.5 \\
\hline 2 & Boron & $45^{\circ}$ & IC & 45 & 81.8 \\
\hline 4 & Boron & $45^{\circ}$ & IC & 75 & 143.8 \\
\hline 6 & Boron & $45^{\circ}$ & IC & 225 & 336.7 \\
\hline 1 & Boron & $45^{\circ}$ & OC & 30 & 41.0 \\
\hline 2 & Boron & $45^{\circ}$ & $O C$ & 45 & 114.7 \\
\hline 4 & Boron & $45^{\circ}$ & OC & 75 & 131.0 \\
\hline 6 & Boron & $45^{\circ}$ & OC & 225 & 327.0 \\
\hline 3 & Perc & Mouth & IC & 45 & 117.5 \\
\hline 5 & Perc & Mouth & IC & 75 & 196.0 \\
\hline 7 & Perc & Mouth & IC & 225 & 408.7 \\
\hline 3 & Perc & Mouth & OC & 45 & 127.7 \\
\hline 5 & Perc & Mouth & OC & 75 & 184.0 \\
\hline 7 & Perc & Mouth & OC & 225 & 418.3 \\
\hline 3 & Perc & Pole & IC & 45 & 89.3 \\
\hline 5 & Perc & Pole & IC & 75 & 148.5 \\
\hline 7 & Perc & Pole & IC & 225 & 446.5 \\
\hline 3 & Perc & Pole & OC & 45 & 114.5 \\
\hline 5 & Perc & Pole & OC & 75 & 153.8 \\
\hline 7 & Perc & Pole & $O C$ & 225 & 361.8 \\
\hline 3 & Perc & $45^{\circ}$ & IC & 45 & 108.8 \\
\hline 5 & Perc & $45^{\circ}$ & IC & 75 & 172.0 \\
\hline 7 & Perc & $45^{\circ}$ & IC & 225 & 436.7 \\
\hline 3 & Perc & $45^{\circ}$ & $O C$ & 45 & 126.8 \\
\hline 5 & Perc & $45^{\circ}$ & OC & 75 & 154.8 \\
\hline 7 & Perc & $45^{\circ}$ & OC & 225 & 391.5 \\
\hline
\end{tabular}



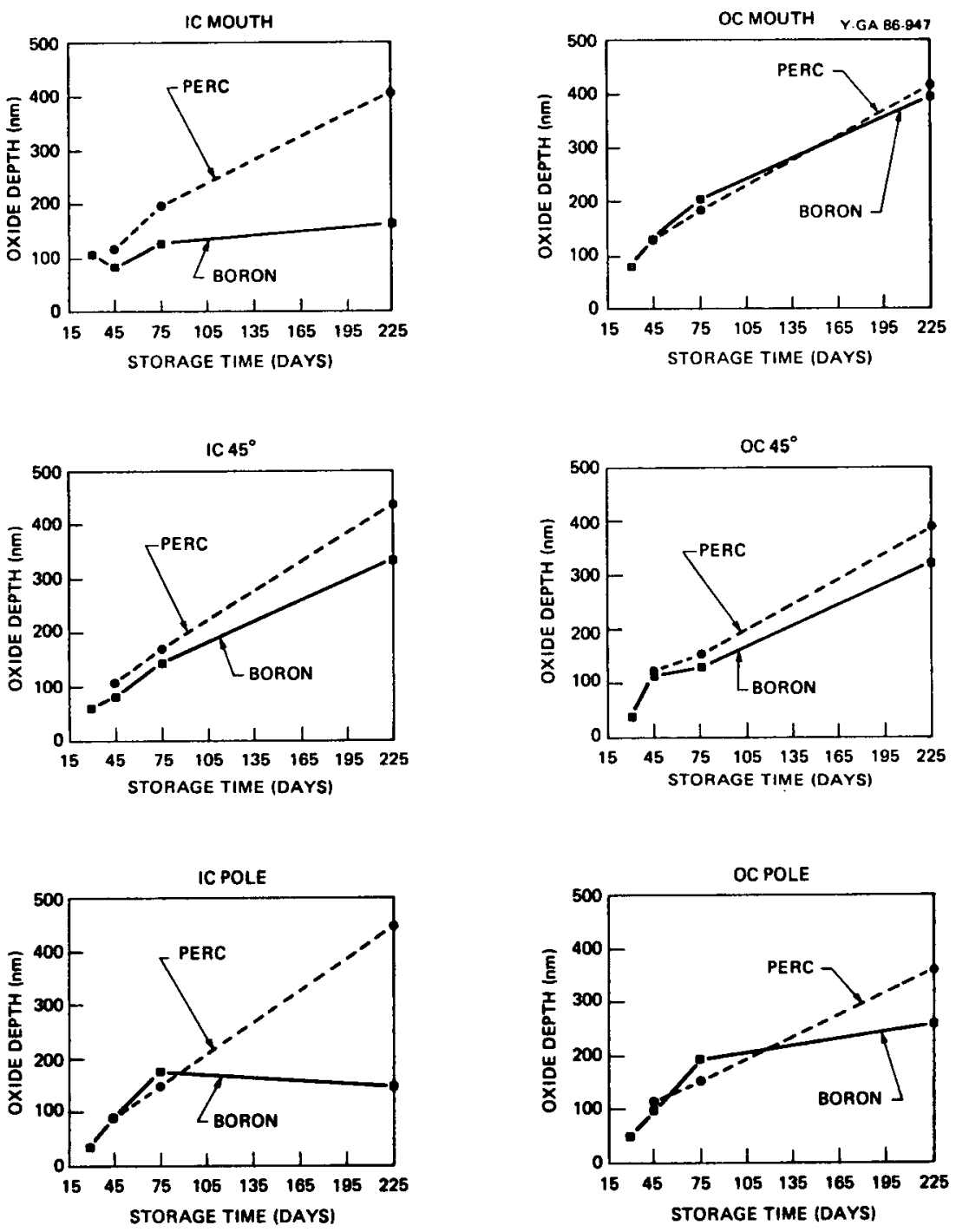

Fig. A.4. Plot of oxide depth treatment means versus days of storage (by surface and position).

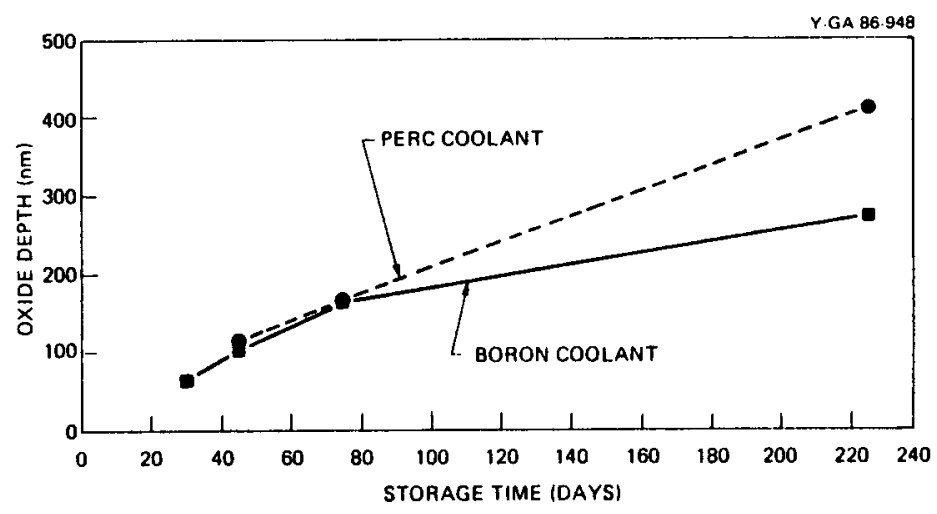

Fig. A.5. Plot of oxide depth treatment means versus days of storage. 
These two regression equations indicate that for 30 to $31 \mathrm{~d}$ of storage, the boron-machined parts have greater oxide depth than the perc-machined parts; for $31.225 \mathrm{~d}$ of storage, the boron-machined parts have lower oxide depth than the perc-machined parts.

\section{A.3 SURFACE MORPHOLOGY AND LOCAL CORROSION}

No data are available.

\section{A.4 ACCELERATED CORROSION TEST RESULTS}

Samples from nine parts were subjected to an accelerated corrosion test. The corrosion rate (mils per year) was determined for a sample from each of three positions (pole, $45^{\circ}$, and mouth) on each of nine parts. An analysis of variance was performed to look for effects on the mean corrosion rate due to the different handling treatments or due to the three positions, and to look for an interaction between position and treatment. The analysis of variance results and sample means are given in Tables A.5 and A.6, respectively.

Table A.5. Accelerated corrosion analysis of variance

\begin{tabular}{|c|c|c|}
\hline Source & D.F. & $\begin{array}{c}\text { Probability } \\
>\mathrm{F}\end{array}$ \\
\hline Treatment & 4 & \\
\hline Storage time & & 0.0219 \\
\hline Coolant & & 0.0038 \\
\hline Storage time $X$ coolant & & 0.3027 \\
\hline Linear storage time (boron coolant) & & 0.7540 \\
\hline Quadratic storage time (boron coolant) & & 0.0802 \\
\hline Part (treatment) & 4 & \\
\hline Position & 2 & 0.9301 \\
\hline Position $X$ treatment & 8 & 0.8153 \\
\hline Residual & 8 & \\
\hline Total & 26 & \\
\hline
\end{tabular}


Table A.6. Accelerated corrosion sample means

\begin{tabular}{cccccc}
\hline Treatment & Coolant & Handing & $\begin{array}{c}\text { Storage } \\
\text { time } \\
(\mathrm{d})\end{array}$ & $\mathrm{n}$ & $\begin{array}{c}\text { Mean } \\
\text { corrosion } \\
\text { rate } \\
\text { (mil/year) }\end{array}$ \\
\hline 1 & Boron & Same as Rocky & 30 & 3 & 0.45 \\
2 & Boron & Standard & 45 & 6 & 0.58 \\
3 & Perc & Standard & 45 & 6 & 0.83 \\
4 & Boron & $\begin{array}{c}\text { Standard }+ \\
1 \text { month }\end{array}$ & 75 & 6 & 0.49 \\
5 & Perc & $\begin{array}{l}\text { Standard }+ \\
1 \text { month }\end{array}$ & 75 & 6 & 0.66 \\
\hline
\end{tabular}

From the analysis of variance results, we can conclude the following:

1. There is a significant decrease in the mean corrosion rate from 45 to $75 \mathrm{~d}$ of storage for both the boron and perc coolants.

2. The perc coolant mean corrosion rate is significantly higher than the boron coolarit mean corrosion rate.

3. There is no significant interaction between storage time and coolant.

4. There is no significant difference in the mean corrosion rate for the three positions (pole, $45^{\circ}$, and mouth).

5. There is no significant interaction between position and treatment.

See Fig. A.6 for a plot of the corrosion rate treatment means.

\section{A.5 COOLANT CHARACTERIZATION}

As part machining progressed, contaminants in the coolant were monitored. Only the uranium content was monitored both in the boron and perc coolants. There are not enough data to reliably assess the existence of any trend in uranium levels in the coolants as a function of the number of parts machined. The data that were collected on uranium content of the two coolants are displayed in Fig. A.7. 


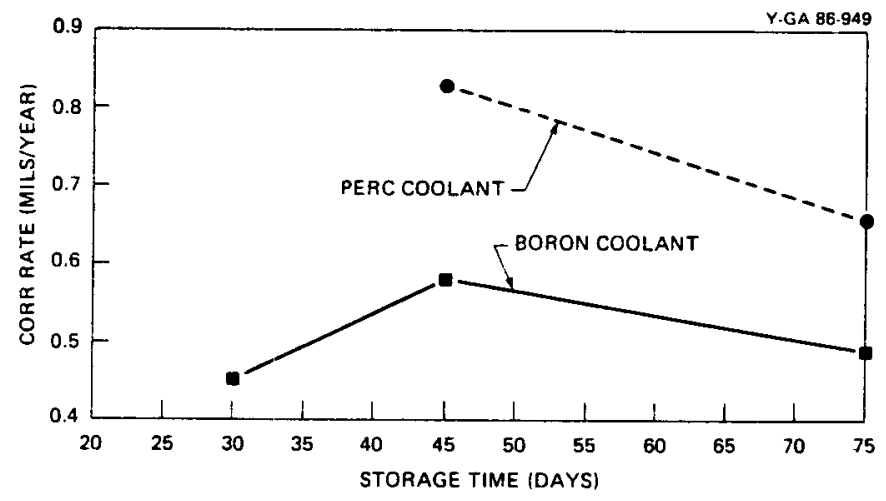

Fig. A.6. Plot of corrosion rate treatment means versus days of storage.

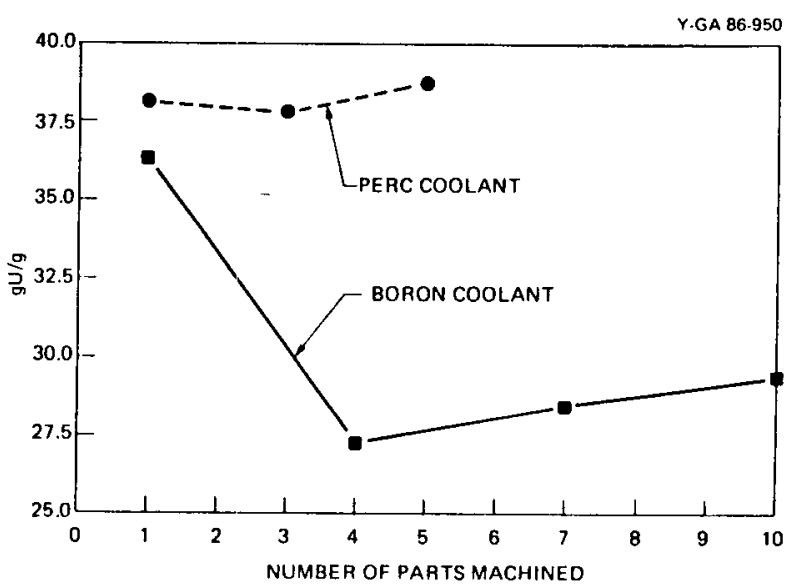

Fig. A.7. Plot of uranium concentration in coolant versus number of parts machined. 
Distribution

Department of Energy - Oak Ridge

Poteat, R. M.

Spence, R. J.

Lawrence Livermore National Laboratory

Clough, R. E./Galles, H. L.

Miller, G. H.

Ragaini, R. C.

Robbins, J. L.

Sanford, C. B.

Seaton, D. L.

Shuler, W. B./Wraith, C. L.

Technical Information Division

Werne, R. W./Grissom, M. L.

\section{Los Alamos National Laboratory}

Dunning, D. N.

Hoyt, H. C.

Waugh, H. G.

Oak Ridge Y-12 Plant

Ardary, Z. L.

Arehart, Jr., T. A.

Asbury, W. L.

Barkman, J. R.

Bennett, R. K.

Burditt, R. B.

Bryant, D. P.

Butler, H. R.

Chapman, L. R.

Cochran, J. L.

Creech, E. T.

Cristy, S. S. (5)

Dean, L. A.

Dillon, J. J.

Dodson, W. H./Googin, J. M.

Duerksen, W. K.

Dyer, E. B.

Fee, G. G.

Ferguson, J. E.

Garber, J. W.

Golshani, A. M.

Guinn, G. R.

Johnson, D. H.

Jones, F. W.

Jones, L. P.

Keith, A. 
Keyser, R. M.

Kite, H. T.

Koger, J. W.

Kollie, T. G.

Kosinski, F. E./Napier, J. M.

Lambdin, Jr., F.

Larson, G. F.

McAlister, R. J.

Mills, Jr., J. M.

Needham, E. D.

Post, D. W.

Richards, H. L.

Seals, R. D.

Shelton, J. T.

Smith, D. W.

Steger, P. J./Roettger, F. J.

Stephenson, M. J.

Taylor, P. A.

Thompson, Jr., W. H.

Townsend, A. B.

Walton, Y. W.

Williams, R. D.

Yaggi, W. J.

Y-12 Central Files (Master)

$Y-12$ Central Files (Route)

Y-12 Central Files (Y-12RC)

$Y-12$ Central Files (5)

Paducah Gaseous Diffusion Plant

Walter, C. W.

Rockwell International-Rocky Flats

Cleavenger, R. D.

Crisler, L. R.

Dorr, J. E.

Sandia National Laboratories - Livermore

Olson, D. M.

In addition, this report is distributed in accordance with the Category UC-25, Materials, as given in the Standard Distribution for Unclassified Scientific and Technical Reports, DOE/TIC-4500. 